\title{
European Red List of Trees
}

Malin Rivers, Emily Beech, loannis Bazos, Faruk Bogunić, Antoni Buira, Danka Caković, André Carapeto, Angelino Carta, Bruno Cornier, Giuseppe Fenu, Francisco Fernandes, Pere Fraga i Arguimbau, Pablo Garcia-Murillo, Martin Lepší, Vlado Matevski, Félix Medina, Miguel Menezes de Sequeira, Norbert Meyer, Vlastimil Mikoláš, Chiara Montagnani, Tiago Monteiro-Henriques, José Naranjo-Suárez, Simone Orsenigo, Antoaneta Petrova, Alfredo Reyes-Betancort, Tim Rich, Per Harald Salvesen, Isabel Santana-López, Stephan Scholz, Alexander Sennikov, Lulëzim Shuka, Luís Filipe Silva, Philip Thomas, Angelo Troia, José Luis Villar, and David Allen

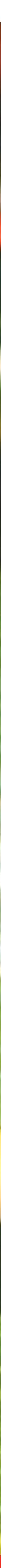

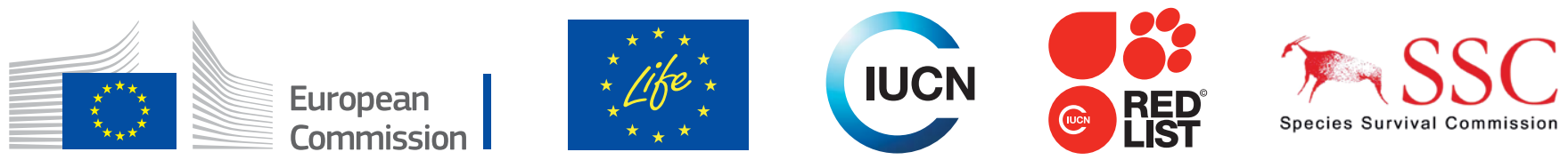




\section{About IUCN}

Created in 1948, IUCN has evolved into the world's largest and most diverse environmental network. It harnesses the experience, resources and reach of its more than 1,300 Member organisations and the input of over 10,000 experts. IUCN is the global authority on the status of the natural world and the measures needed to safeguard it. Our experts are organised into six commissions dedicated to species survival, environmental law, protected areas, social and economic policy, ecosystem management, and education and communication

www.iucn.org

twitter.com/IUCN

\section{IUCN - Global Species Programme}

The IUCN Global Species Programme supports the activities of the IUCN Species Survival Commission and individual Specialist Groups, as well as implementing global species conservation initiatives. It is an integral part of the IUCN Secretariat and is managed from IUCN's international headquarters in Gland, Switzerland. The Species Programme includes a number of technical units including the IUCN Red List Unit, Species Trade and Use, Freshwater Biodiversity Unit (all located in Cambridge, UK), the Global Biodiversity Assessment Initiative (located in Washington DC, USA), and the Marine Biodiversity Unit (located in Norfolk, Virginia, USA).

www.iucn.org/species

\section{IUCN Species Survival Commission}

With over 8,000 members, the Species Survival Commission (SSC) is the largest of the six expert commissions of IUCN and enables IUCN to influence, encourage and assist societies to conserve biodiversity by building knowledge on the status and threats to species, providing advice, developing policies and guidelines, facilitating conservation planning, and catalysing conservation action.

Members of SSC belong to one or more of the 140 Specialist Groups, Red List Authorities, Task Forces and Conservation Committees, each focusing on a taxonomic group (plants, fungi, mammals, birds, reptiles, amphibians, fishes and invertebrates), or a disciplinary issue, such as sustainable use and livelihoods, reintroduction of species, wildlife health, climate change and conservation planning.

www.iucn.org/theme/species/about/species-survival-commission 


\section{European Red List of Trees}

Malin Rivers, Emily Beech, loannis Bazos, Faruk Bogunić, Antoni Buira, Danka Caković, André Carapeto, Angelino Carta, Bruno Cornier, Giuseppe Fenu, Francisco Fernandes, Pere Fraga i Arguimbau, Pablo Garcia-Murillo, Martin Lepší, Vlado Matevski, Félix Medina, Miguel Menezes de Sequeira, Norbert Meyer, Vlastimil Mikoláš, Chiara Montagnani, Tiago Monteiro-Henriques, José Naranjo-Suárez, Simone Orsenigo, Antoaneta Petrova, Alfredo Reyes-Betancort, Tim Rich, Per Harald Salvesen, Isabel Santana-López, Stephan Scholz, Alexander Sennikov, Lulëzim Shuka, Luís Filipe Silva, Philip Thomas, Angelo Troia, José Luis Villar, and David Allen 
The designation of geographical entities in this book, and the presentation of the material, do not imply the expression of any opinion whatsoever on the part of IUCN concerning the legal status of any country, territory, or area, or of its authorities, or concerning the delimitation of its frontiers or boundaries.

The views expressed in this publication do not necessarily reflect those of the European Commission or of IUCN.

This publication has been prepared by IUCN as a deliverable of the LIFE European Red Lists project (LIFE14 PRE/BE/000001).

Project Title: Establishing a European Red List of Bryophytes, Pteridophytes, Saproxylic Beetles, Terrestrial Molluscs and Vascular Plants (LIFE European Red Lists; LIFE14 PRE/BE/000001)

Project duration: May 2015 to September 2019

Project total costs: $1,166,667$ EUR

Contribution of the LIFE Programme: 700,000 EUR

Co-financers of the project: National Parks and Wildlife Service, Republic of Ireland; Ministry of Economic Affairs, Department of Nature \& Biodiversity (Ministerie van Economische Zaken, Directie Natuur \& Biodiversiteit), the Netherlands; Council of Europe; Office fédéral de l'Environnement, Switzerland; Swedish Environmental Protection Agency (Naturvardsverket), Sweden; British Entomological Society, United Kingdom; Ministry of Sustainable Development and Infrastructure, Government of the Grand-Duché of Luxembourg.

The LIFE Programme (https://ec.europa.eu/easme/en/life) is the EU's financial instrument supporting environmental, nature conservation and climate action projects throughout the EU. The general objective of LIFE is to contribute to the implementation, updating and development of EU environmental, nature conservation and climate policy and legislation by cofinancing projects with European added value.

Published by: IUCN, Cambridge, UK and Brussels, Belgium

Copyright: (c) 2019 IUCN, International Union for Conservation of Nature and Natural Resources. All rights reserved. Licensed to the European Union under conditions. Reproduction of this publication for educational or other non-commercial purposes is authorised without prior written permission from the copyright holder provided the source is fully acknowledged. Reproduction of this publication for resale or other commercial purposes is prohibited without prior written permission of the copyright holder.

Citation:

Rivers, M.C., Beech, E., Bazos, I., Bogunić, F., Buira, A., Caković, D., Carapeto, A., Carta, A., Cornier, B. Fenu, G., Fernandes, F., Fraga, P., Garcia Murillo, P.J., Lepší, M., Matevski, V., Medina, F.M., Menezes de Sequeira, M., Meyer, N., Mikoláś, V., Montagnani, C., Monteiro-Henriques, T., Naranjo Suárez, J., Orsenigo, S., Petrova, A., Reyes-Betancort, J.A., Rich, T., Salvesen, P.H., Santana López, I., Scholz, S., Sennikov, A., Shuka, L., Silva, L.F., Thomas, P., Troia, A., Villar, J.L. and Allen, D.J. (2019) European Red List of Trees. Cambridge, UK and Brussels, Belgium: IUCN. viii +60pp.

ISBN:

978-2-8317-1985-6 (PDF)

978-2-8317-1986-3 (print)

DOI:

https://doi.org/10.2305/IUCN.CH.2019.ERL.1.en

Design and layout:

Imre Sebestyén jr. / UNITgraphics.com

Printed by:

Media Process S.A., Brussels

Available from:

IUCN (International Union for Conservation of Nature)

64 Boulevard Louis Schmidt, 1040 Brussels, Belgium

brussels@iucn.org

www.iucn.org/resources/publications

Picture credits on cover page: Sorbus bohemica Kovanda (Endangered) is endemic to the České středohoří (Central Bohemian Uplands) in Czechia, where it is threatened by the cessation of traditional forest management which maintained open forests. Credit: Martin Lepší.

All photographs used in this publication remain the property of the original copyright holder (see individual captions for details). Photographs should not be reproduced or used in other contexts without written permission from the copyright holder.

Printed in Belgium. The text of this book is printed on $135 \mathrm{gsm}$ silk paper (the cover on $300 \mathrm{gsm}$ silk). This book is printed on recycled paper made from wood fibre from well-managed forests certified in accordance with the rules of the Forest Stewardship Council (FSC). 


\section{Contents}

Foreword

Acknowledgements

Executive summary vii

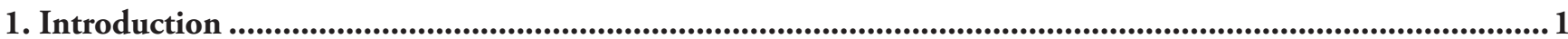

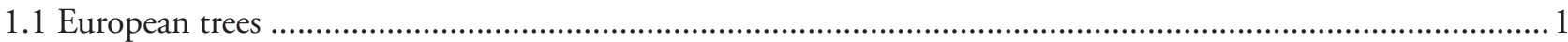

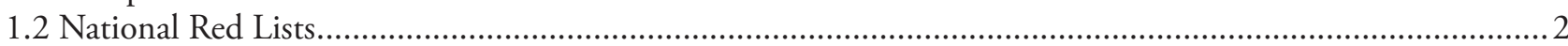

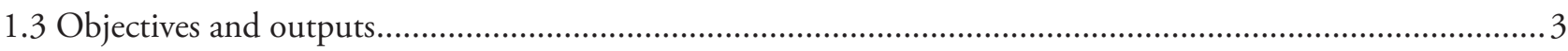

2. Methods

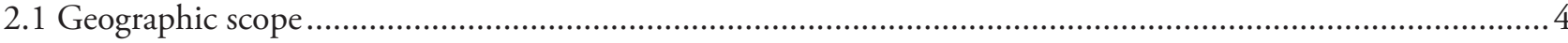

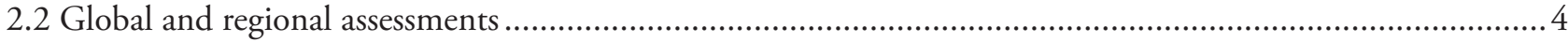

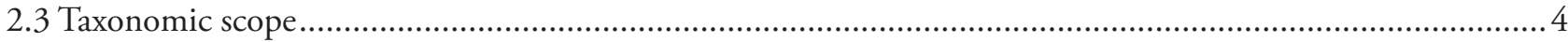

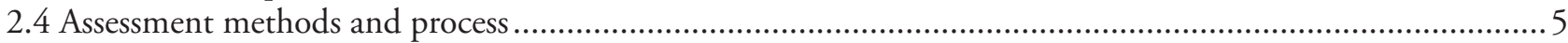

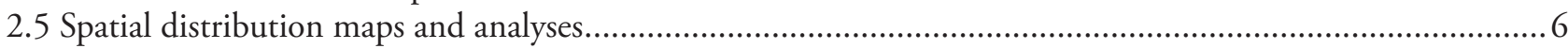

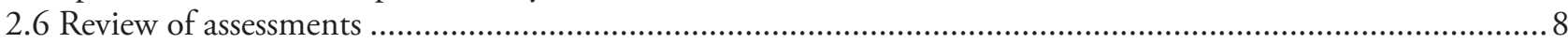

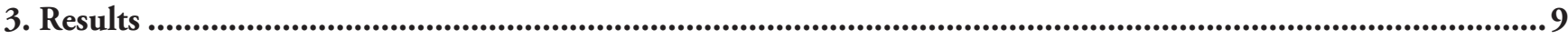

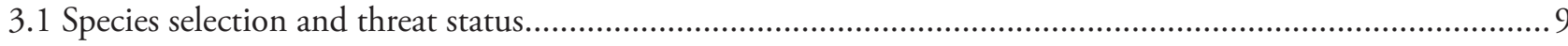

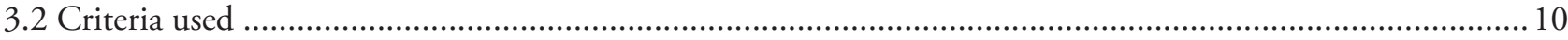

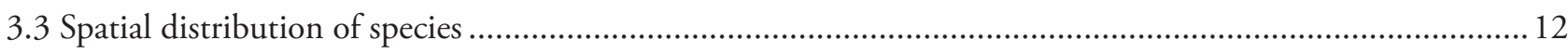

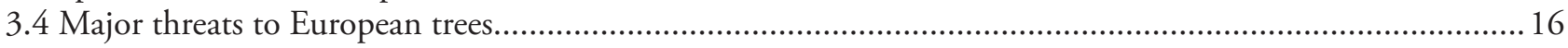

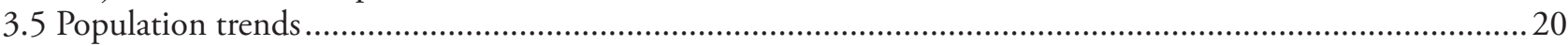

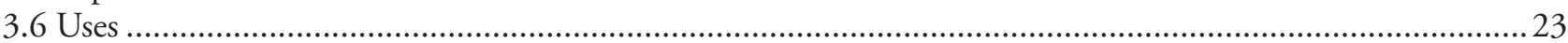

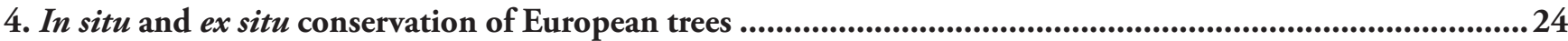

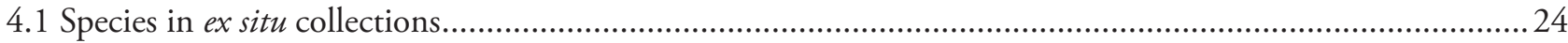

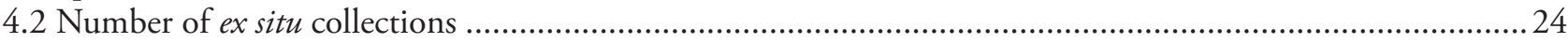

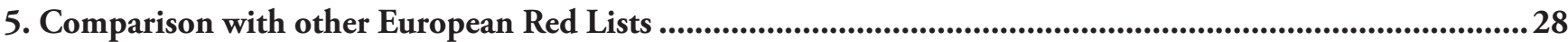

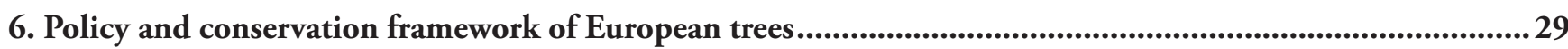

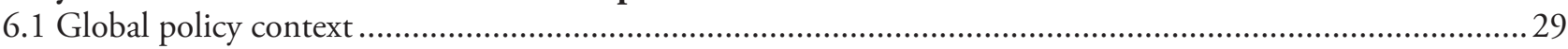

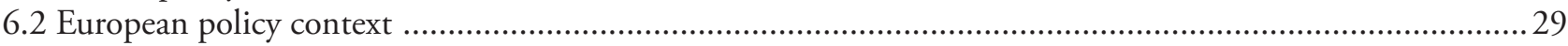

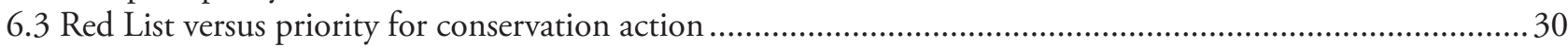

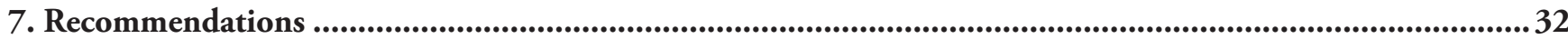

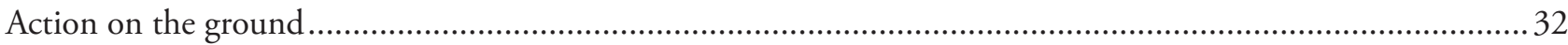

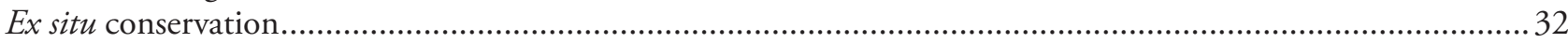

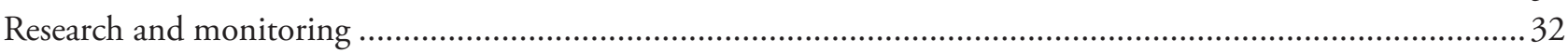

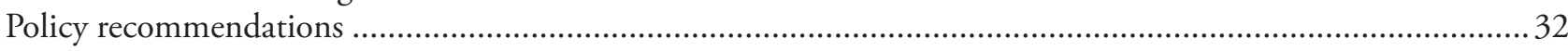

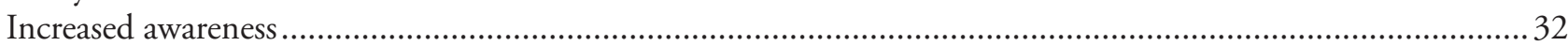

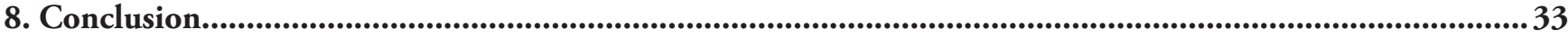

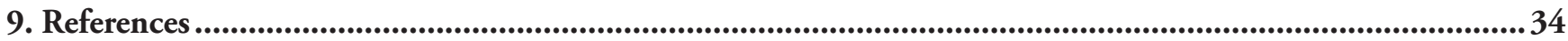

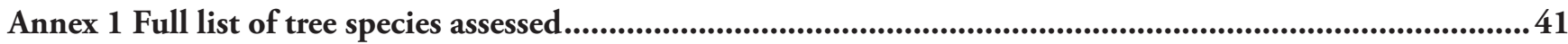

Annex 2 Summary of the IUCN Red List Category and Criteria...............................................................................52

Annex 3 Example of species summary and distribution map ................................................................................53 


\section{Foreword}

The European continent has a rich and varied natural heritage, however, Europe's landscape has been shaped by centuries of land use and land change through diverse farming and forestry traditions, as well as more recent urbanisation trends. As a result, a mosaic of natural, semi-natural, managed and artificial landscapes has developed and the continent's habitats and biodiversity has undergone significant declines. Many of Europe's ecosystems are now so heavily degraded that their ability to deliver valuable ecosystem services has been drastically reduced. The EU Biodiversity Strategy is part of a 2050 vision aiming to protect, value and restore biodiversity and the services it provides - its natural capital. This is important not only to protect nature's non-instrumental value, but also for its essential contribution to human wellbeing and economic prosperity, and to avert catastrophic changes caused by the loss of biodiversity.

In recent years, awareness has risen surrounding the crucial role of plants - and especially trees - in providing ecosystem services and on the threats that they face. Trees are one of the essential foundations of healthy ecosystems that we depend on, including the European forest landscape, a mosaic largely shaped by people. However, significant gaps in knowledge still remain. In this context, this European Red List of Trees provides the first ever comprehensive assessment of the extinction risk of all tree species that are native to Europe. With all 454 species assessed, this assessment highlights that $42 \%$ of European tree species are considered threatened (i.e. assessed as Critically Endangered, Endangered or Vulnerable) and therefore having a high risk of extinction. The primary threat to tree species in Europe has been identified as invasive or problematic species, including disease and tree pests, affecting 38\% of all tree species. Deforestation, degradation, wood harvesting and urban development are other significant threats. For threatened species, livestock farming, land abandonment and other ecosystem modifications are the major threats, impacting the survival of trees and their habitats. The assessment indicates that they are the second most threatened group of plant species assessed to date for the IUCN European Red List - and the third most threatened group overall, only exceeded by the freshwater molluscs and by the 'policy plants' (plant taxa listed in European and international policy instruments). By comparison, amongst the plants, $2 \%$ of medicinal plants, $8 \%$ of aquatic plants, $16 \%$ of crop-wild relatives, $20 \%$ of ferns and lycopods, $22 \%$ of bryophytes, and $57 \%$ of the 'policy plants' are threatened.

It is clear that Europe therefore has a responsibility to conserve these unique species that contribute so much to the landscapes, ecosystems and economies of Europe. One encouraging finding is that nearly $80 \%$ of species are found in at least one protected area, including the Natura 2000 network. Measures must be taken in order to improve the status of European trees. These assessments complement existing national conservation assessments to allow targeted conservation planning, and the outcomes of this initiative should be used to develop policy to ensure that the species considered threatened are protected both in and ex situ; and to inform, inspire and catalyse research and conservation action to prevent the extinction of European tree diversity.

I hope that this new IUCN European Red List will help place trees high on the conservation agenda, as well as inform the wider debate and contribute to the discussion on priorities within the conservation community. This work complements work already undertaken within the European Union to understand and conserve forests, such as the European Atlas of Forest Tree Species and the EU Forest Strategy. Investment in scientific research, and increasing awareness and communications will help towards the delivery of targeted conservation actions and positive impacts for these species.

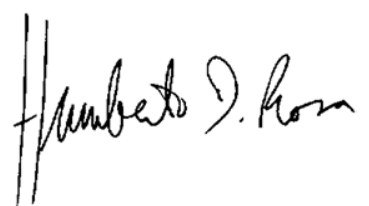

Humberto Delgado Rosa

Director for Natural Capital

DG Environment, European Commission 


\section{Acknowledgements}

The European Red List of Trees project was coordinated by David Allen (IUCN) with immense support from colleagues at IUCN, Ana Nieto Serradilla, Mariana García Criado, and Marta Cálix. The project was implemented by Malin Rivers and Emily Beech and colleagues at Botanic Gardens Conservation International (BGCI), who compiled the list of species to be included, drafted the majority of assessments, undertook all analyses, and wrote the report. The co-authors of this publication are the many experts who participated in the assessment review workshops, Emily Beech (BGCI), Malin Rivers (BGCI) and David Allen (IUCN).

All of the European Red List assessment projects rely on the willingness of scientists who are often, but not always, members of the IUCN Species Survival Commission (SSC), who pool and contribute their collective knowledge to make the most reliable estimates of a species' conservation status and distribution. Without their dedicated commitment to species conservation, this kind of assessment project would not be possible. These experts are either the assessors and contributors to the IUCN Red List species assessments that have been completed through this and earlier projects, or provided their time and expertise to review species assessments at review workshops or by email. We would like to express our sincere thanks to all who have contributed as assessment Assessors, Reviewers and Contributors, and our apologies if they are omitted here in error. Those experts and former or current IUCN staff who contributed to this work through assessing, compiling or reviewing the species assessments are as follows;
Hossein Akhani, Mostafa Alaoui, Antun Alegro, Jelena Aleksić, Alexander Alexandrov, Rafael S. Almeida Pérez, Montserrat Arista, Mora Aronsson, Åsmund Asdal, Michael Avishai, Gianluigi Bacchetta, Olga Baeta, Simonetta Bagella, Dalibor Ballian, Angel Bañares Baudet, Megan Barstow, Denes Bartha, Irina Belyaeva-Chamberlain, Melanie Bilz, Igor Boršić, Ferdinando Branca, Zofia Bulińska, Francisco Barreto Caldas, Eduardo Carqué Álamo, José Augusto Carvalho, Mariana Carvalho, Helen Chadburn, Tom Christian, Charalambos Christodoulou, Andreas Christou, Leah Collett, Dan Crowley, Annabelle Cuttelod, Gérard de Bélair, Bertrand de Montmollin, Marcelino del Arco Aguilar, Pinelopi Delipetrou, Panayotis Dimopoulos, Gianniantonio Domina, Domizia Donnini, David Draper Munt, Maria Cristina Duarte, Ehsan Dulloo, Garifalia Economou, Bernhard Egli, Pavol Eliáš, Stefan Ericsson, Aljos Farjon, Laurence Fazan, Viera Ferakova, Hafawa Ferchichi, Ángel Fernández López, Di Flanagan, Bruno Foggi, Christina Fournaraki, David Frey, Mariana García-Criado, Nieves García, Lauren Gardiner, Martin Gardner, Giuseppe Garfi, Domenico Gargano, Shanina Ghazanfar, Zeineb Ghrabi-Gammar, Belgin Göçmen Taşkın, Bárbara Goettsch, Vildan Gorener, Patrick Grillas, Serene Hargreaves, Yvette Harvey-Brown, Stephen Herrington, Iva Hodálová, Vojtech Holubec, Laetitia Hugot, Marilena Idzojtic, Dusan Isajev, Devin Johnson, Costa Kadis, Salih Kavak, Shelagh Kell, Chris Kik, Gergely Király, Sabina Knees, Helena Korpelainen, Gregor Kozlowski, Dario Kramer, Angelos Kyratzis, Juozas Labokas, Richard V. Lansdown, Danna Leaman, Lucia Lopez Poveda, Daniel Luscombe, Joana Magos Brehm, Manuel Marrero Gómez, Águedo Marrero-Rodríguez,

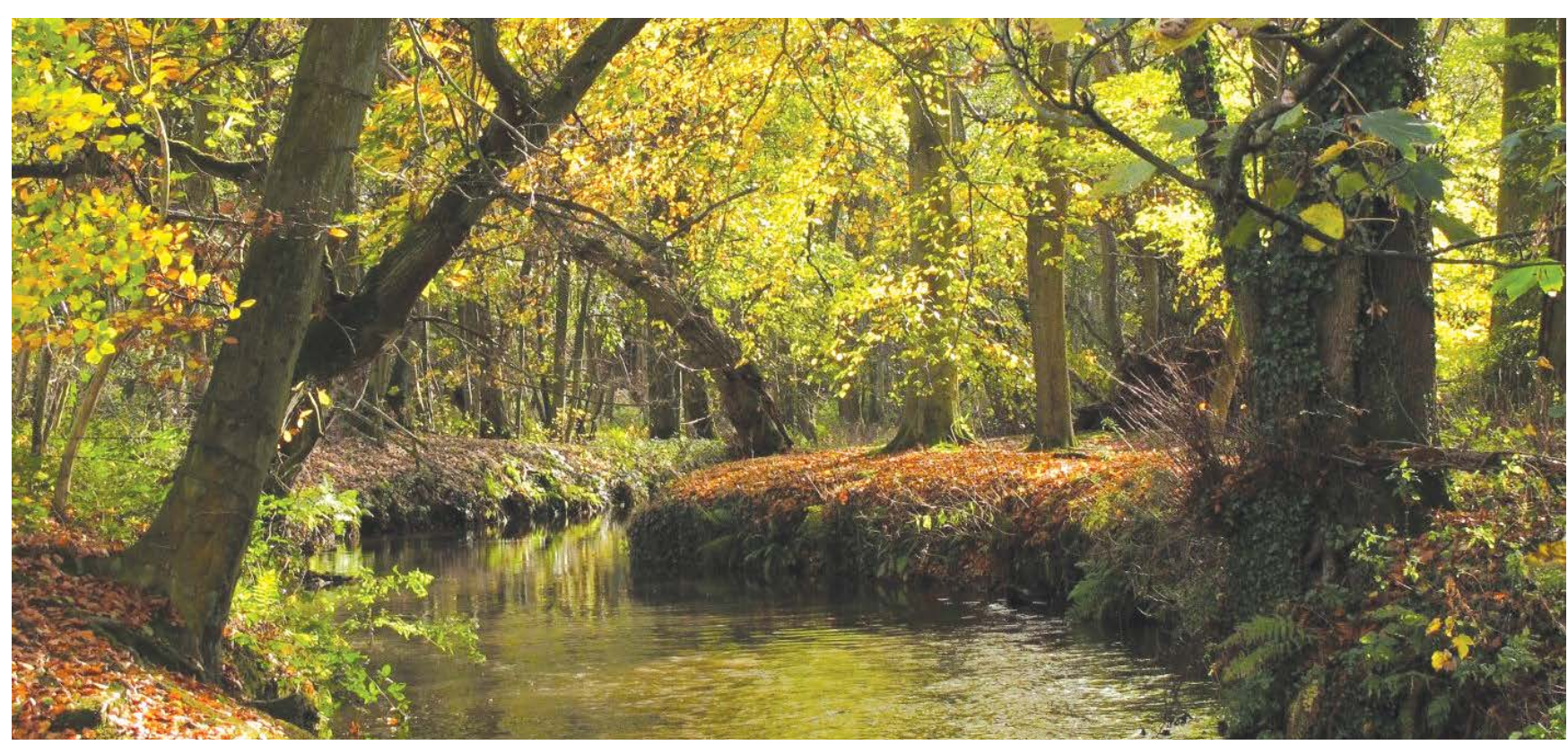

Riverine woodland along the River Wey near Headley Park, southern England. () John Spooner (CC BY-NC 2.0) 
Oleg Maslovky, Milan Mataruga, Izolda Matchutadze, Nigel Maxted, Stephen Mifsud, Rebecca Miller, Pablo Moreno Cárdenas, Patrik Mráz, Serge Muller, Csaba Németh, Ana Nieto, Elizabeth Ojeda Land, Sara Oldfield, Ana OrtegaOlivencia, Joanna Osborne, Özge Ozden, Salvador Pasta, María Dolores Peraza Zurita, Aline Perez Graber, Lorenzo Peruzzi, Danka Caković, Stergios Pirintsos, Daniela Requena Suarez, Laila Rhazi, Mouhssine Rhazi, Naomi Rich, Josep Rosselló, Shyamali Roy, Beatriz Rumeu Ruiz, Terhi Ryttäri, Llorenç Sáez Goñalons, Pedro Sánchez Gómez, Rosario Schicchi, Fabian Schweizer, Kirsty Shaw, Isamberto Silva, Lajos Somlyay, Pedro Sosa Henríquez, Chrissie Stanley, Vladimir Stevanović, Darrin Stevens, Silvia Strajeru, Arne Strid, Andrii Tarieiev, Maria do Carmo Tavares, Helen Temple, Jean-Marc Tison, Néstor Torres, Panagiotis Trigas, Dana Turonova, Katya Uzundzhalieva, An Vanden Broeck, Errol Véla, Jiří Velebil, Rudolf Vögel, Gabor Vörösváry, Martin Wigginton and Brett Wilson.

A number of IUCN SSC Specialist Groups have assisted in the compilation and review of assessments. These include: the Conifer Specialist Group (Philip Thomas), the Crop Wild Relative Specialist Group (Nigel Maxted, Shelagh Kell, Joana Brehm), the Freshwater Plant Specialist Group (Richard Lansdown), the Global Tree Specialist Group (Sara Oldfield and Dan Crowley), the Macaronesian Island Plant Specialist Group, and the Mediterranean Plant Specialist Group.

We thank the Committee for Mapping the Flora of Europe (Atlas Florae Europaeae) for making plant distribution data available for a significant number of species included in this assessment. Especial thanks are due to Alexander Sennikov, Secretary of the Committee, who made significant contributions to review workshops and facilitated the use of AFE data. The Botanical Society of Britain and Ireland (BSBI) kindly provided access to their record data, which greatly improved the distribution maps for a number of species.

We are indebted to the hosts of the three Red List assessment review workshops that brought together botanical experts from across the region. They were: Croatia, Sanja Kovačić and Vanja Stamenkovic, The Botanical Garden of the Faculty of Science of the University of Zagreb (Sorbus species, June 2016); Italy, Andrea Di Giulio and Graziano Rossi (Dipartimento di Scienze della Terra e dell'Ambiente of the University of Pavia) and Gian Attilio Sacchi, Ilda Vagge, and Simone Orsenigo (Dipartimento di Scienze Agrarie e Ambientali-Produzione, Territorio, Agroenergia of the University of Milan), with the workshop held at the University of Pavia Botanical Garden (various tree genera, October 2016); and Canaries, Spain, Juli Caujapé Castells,
Jardín Botánico Canario "Viera y Clavijo", Las Palmas, Gran Canaria (Macaronesian species, January 2017).

Colleagues from BGCI Red List Programme (Yvette HarveyBrown, Helen Rawlinson, and Lydia Murphy) have provided time and hard work towards these assessments. Many thanks to all the institutions contributing ex situ collection data for this report.

Numerous colleagues from the IUCN Global Species Programme have provided assistance throughout the project, with Jemma Window providing mapping training and support, coordinating the production of maps, and leading on the analysis of spatial data. Red List Unit staff (Craig Hilton-Taylor, Caroline Pollock, and Ackbar Joolia) provided guidance throughout. We would like to thank IUCN colleagues in Cambridge (Mickael Chevalier, Amy Burden and Aisha Ghauri) and Gland (Anna Rosenberg) who have worked tirelessly with all project reporting and financial issues. Katharina Lapin and Kevin Smith contributed to the section on alien invasive and problematic species.

We thank the Federal Department for the Environment (FOEN), Switzerland, for their significant financial contribution to the European Vascular Plant Assessment project, which supported the three assessment review workshops, allowing us to ensure expert representation from across the European region.

This publication benefitted greatly from comments and suggestions made by the external reviewers; Steven Bachman (Royal Botanic Gardens, Kew), Daniele de Rigo (external consultant for the European Commission (ARCADIA SIT s.r.l) and Maieutike Research Initiative), Achille Mauri (Joint Research Centre, JRC), Tracy Houston Durrant (external consultant for the European Commission; (GFT Italia s.r.l), and Giovanni Caudullo (External consultant for the European Commission; (Engineering Ingegneria Informatica S.p.A.).

The European Red List of Trees, including this publication, are outputs of a LIFE project co-funded by the European Commission and other donors (LIFE14 PRE/BE/000001 Establishing a European Red List of Bryophytes, Pteridophytes, Saproxylic Beetles, Terrestrial Molluscs and Vascular Plants). In particular, we would like to thank Frank Vassen (European Commission, DG Environment) and the LIFE monitors for their support throughout the project, allowing for a smooth implementation. Any opinions, findings, and conclusions or recommendations expressed in this material are those of the authors and do not necessarily reflect the views of the European Commission, IUCN, or the IUCN Species Survival Commission. 


\section{Executive summary}

The European Red List of Trees is a review of the conservation status of all the European tree species according to IUCN's regional Red List guidelines. It identifies those species that are threatened with extinction at the European regional level to inform the conservation actions needed to improve their conservation status. The geographical scope extends from Iceland in the west to the Urals in the east, and from Franz Josef Land in the north to the Canary Islands in the south. Red List assessments are made at two regional levels: for continental Europe, and for the 28 Member States of the European Union.

This European Red List publication summarises the results for the Red List assessment of all known native European trees, a total of 454 species, of which over 58\% (265 species) are endemic to continental Europe, with 56\% (252 species) endemic to the $28 \mathrm{EU}$ Member States.

Overall, 42\% of European tree species have been assessed as threatened (i.e. assessed as Critically Endangered, Endangered or Vulnerable) and therefore having a high risk of extinction. This report reveals that trees are one of the most highlythreated groups of species that have yet been assessed for the European Red List, exceeded only in their risk of extinction by freshwater molluscs (59\%; Cuttelod et al., 2011) and by the plant species (57\%; Bilz et al., 2011) that are listed in European and international policy instruments, such as the Bern Convention.

A further 13 species are assessed as Near Threatened, almost meeting the criteria for a threatened category; and 216 species are considered Least Concern and therefore not of current conservation concern. However, for 57 species there was insufficient information to assign a conservation status, and are therefore classified as Data Deficient.
The main threat to tree species in Europe has been identified as invasive or problematic species, impacting 38\% of tree species, followed by deforestation and wood harvesting, and urban development (both affecting 20\% of tree species). For threatened species, livestock farming, land abandonment, changes in forest and woodland management, and other ecosystem modifications such as fire are the major threats, impacting the survival of trees.

Out of all European trees, 359 species (79\%) are currently known to occur in at least one protected area and 393 European tree species $(87 \%)$ are found in ex situ collections in botanic gardens and arboreta.

Assessments are available on the EU data portal and on the IUCN European Red List website ec.europa.eu/environment/ nature/conservation/species/redlist and www.iucnredlist.org/ regions/europe

Trees are essential for life on earth and are a key component of the cultural, economic and natural landscapes of Europe. The European Red List of Trees not only recognises the importance of tree species in Europe, but also represents the first comprehensive assessment of the threat status of the region's tree species and details the threats affecting these species, and assesses their risk of extinction. These assessments complement existing regional or national conservation assessments to allow targeted conservation planning. The assessments should be used to inform and direct policy to ensure that the species considered threatened are protected both in and ex situ; and to inform, inspire and catalyse conservation action to prevent the extinction of European tree diversity. 


\section{Key messages and recommendations}

\section{Outcomes}

- 454 tree species are native to the European region (431 to the EU Member States).

- 168 species are considered threatened (Critically Endangered, Endangered and Vulnerable) in Europe with 57 species considered Data Deficient (161 and 54 respectively for the EU Member States).

- Taking into account the number of Data Deficient species, the proportion of threatened species could lie between $37.1 \%$ (if no DD species are considered threatened) and $49.6 \%$ (if all DD species are considered threatened) for Europe. The mid-point value $(42.3 \%)$ provides the best estimate of the proportion of threatened tree species in Europe.

- Almost all the threatened species are endemic to the European region; only thirteen threatened trees are nonEuropean endemics. This means at least 58\% (155 species) of all endemic European trees are threatened.

\section{Recommendations}

\section{Action on the ground}

- Assess the impact of changes in habitat management for all species of tree to determine whether these processes are beneficial to certain species.

- Implement effective protected area management.

- Ensure that that all tree species are adequately represented in protected areas.

\section{Ex situ conservation}

- Expand ex situ collections to incorporate threatened species not found in ex situ collections as a priority.

- Diversify collections of threatened species to incorporate increased genetic diversity to make material available for restoration purposes.

- Increase the collections of species in their country of origin.

\section{Research and monitoring}

- Improved monitoring and evaluation processes are needed to identify potential threats to European trees, as well as research into control and eradication measures.

- Undertake further research into the impacts of climate change on both forest landscapes and individual species, including the scope for range migration and connectivity (Meier et al., 2011).

- Undertake necessary research to determine the conservation status of the Data Deficient tree species of Europe.

- Promote transboundary collaborations and a robust network of experts.

\section{Policy recommendations}

- Update the European Red List of Trees at least every decade to ensure that information about taxa and their threat status is kept up to date, and to allow trends to be elucidated.

- Repeated assessments would allow for the development of a Red List Index for European tree species (EEA, 2010).

- Implement strategies at national levels to mobilise necessary actions to protect threatened tree species and their habitats.

\section{Increased awareness}

- Promote the findings and recommendations of the European Red List of Trees to diverse audiences and stakeholders within countries to increase knowledge of the threats faced by European trees. 


\section{Introduction}

\subsection{European trees}

Trees are essential for life on earth. They provide important ecosystem services, amongst them water purification, carbon storage, oxygen production, and soil stabilisation, and contribute to landscapes and human economies. Tree species are often foundation species - defining entire ecosystems, increasing biodiversity and playing a vital role of many other species of organisms (Ellison et al., 2005). The resource and economic contribution of trees and forest within Europe are significant; forest products contributed one-third of the biomass in Europe in 2013 (Camia et al., 2018) and the forestry sector (forestry and logging, and wood and paper products) had a turnover of 410 billion euros in the European economy and employed 2,589,288 people in 2015 (Ronzon \& M'Barek, 2018). This European Red List of Trees report not only recognises the importance of tree species in Europe, but details the threats affecting these species, and assesses the risk of extinction.
Across Europe, trees are found in a range of habitat types, including forests, shrubland and grasslands. They also grow in urban environments and in or near man-made habitats such as arable land, plantations and mining sites. Trees are most closely associated with forest habitats where they are the dominant lifeform, providing a habitat for many other species of plants, fungi and animals. The European Red List of Habitats (Janssen et al., 2016) recognises 42 forest habitat types across the European continent ranging from single species dominant forest such as 'Pinus sylvestris taiga woodland' to diverse forests such as 'Macaronesian Laurisilva'. Forests cover approximately $33 \%$ of the total European land area (215 million ha) (San-Miguel-Ayanz et al., 2016), although all tree species are not evenly distributed across habitats.

It is clear that anthropogenic interactions with tree species have already led to a decline in forest habitats directly through deforestation and land-use change. Trees are also affected by environmental factors such as pests and diseases (Millar \& Stephenson, 2015). Tree species are all indirectly threatened by climate change which

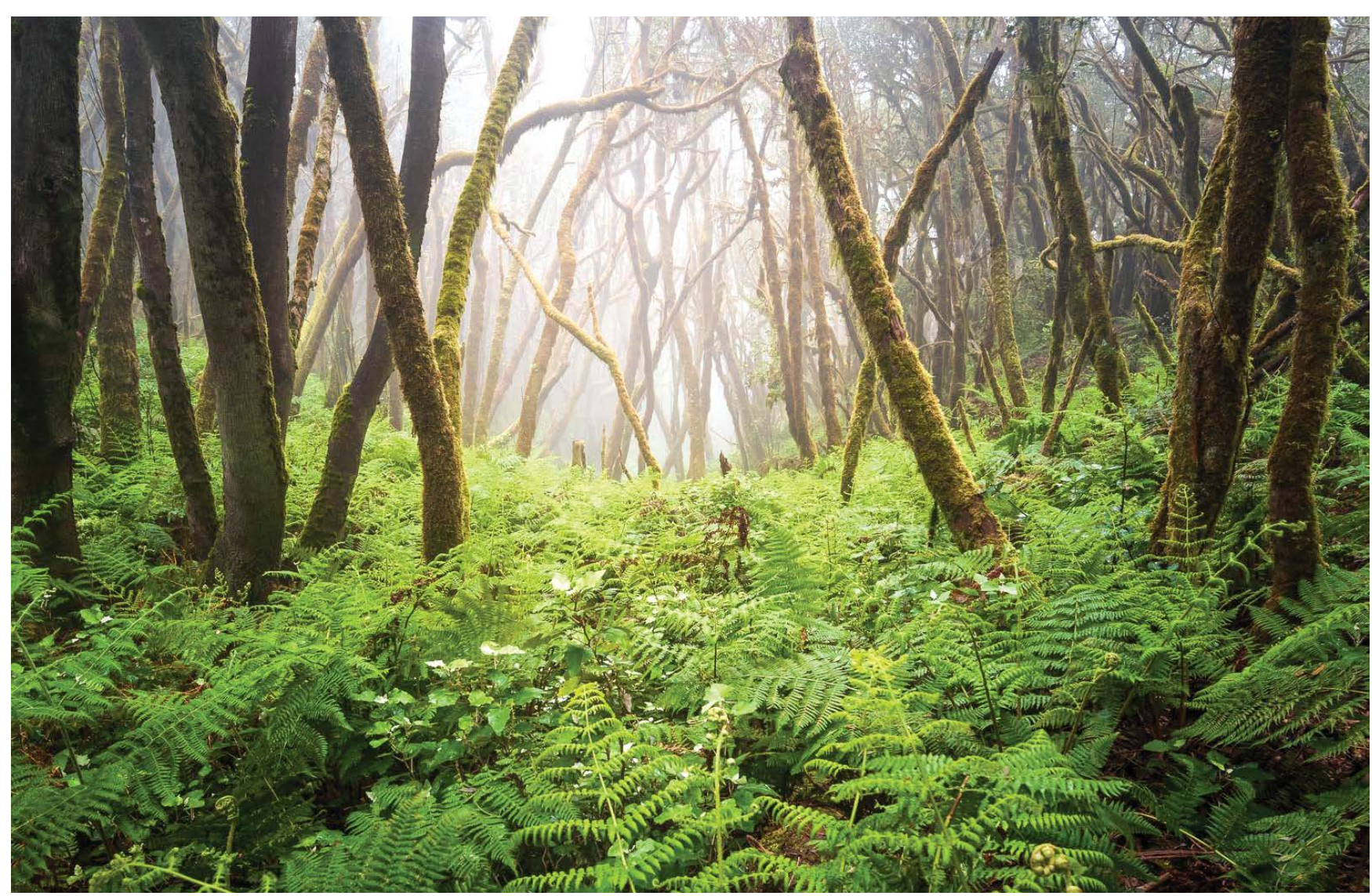

Laurisilva forest on the island of La Gomera (Canary Islands). (C) Raico Rosenberg (CC BY-NC-ND 2.0) 


\section{Box 1: Global Tree Assessment (GTA)}

Despite the importance of trees, many species are threatened by over-exploitation and habitat destruction, as well as by pests, diseases, drought and their interaction with global climate change. In order to understand the impact of such threats to trees there is an urgent need to conduct an assessment of the conservation status of all the world's trees (approx. 60,000 species) - the Global Tree Assessment.

The Global Tree Assessment aims to provide conservation assessments of all the world's tree species by 2020 . The assessment will identify those tree species that are at greatest risk of extinction. The goal of the Global Tree Assessment is to provide prioritization information to ensure that conservation efforts are directed at the right species so that no tree species becomes extinct.

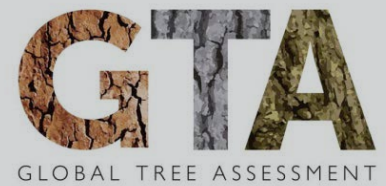

The Global Tree Assessment is an initiative led by BGCI and the IUCN/SSC Global Tree Specialist Group. Work is ongoing to develop an even more extensive global collaborative partnership, involving the coordinated effort of many institutions and individuals. These steps will enable the Global Tree Assessment to achieve its 2020 target. Find out more about the Global Tree Assessment at www.globaltreeassessment.org.

will bring changes in microclimates, fire regimes, water availability and temperature over the coming decades. Here, for the first time, the threat assessments to all tree species of Europe are presented, but the need for further research is clear, with inadequate data for many species (those considered Data Deficient), and risks and impacts arising from some threats, climate change for example, not well understood.

This report is a contribution to Target 2 of the Global Strategy for Plant Conservation (GSPC) which states that by 2020 , there should be 'an assessment of the conservation status of all known plant species, as far as possible, to guide conservation action'. This project also contributes directly to the Global Tree Assessment, an initiative of Botanic Gardens Conservation International (BGCI) and the IUCN/SSC Global Tree Specialist Group (GTSG) to assess the extinction risk all the world's tree species by 2020 (Box 1, Newton et al., 2015; Rivers, 2017).

\subsection{National Red Lists}

Europe was one of the first regions to publish a regional list of threatened plants the (IUCN, Threatened Plants Committee, 1977), with later updates (IUCN Conservation Monitoring Centre, 1983), and IUCN has developed European Red Lists from the mid-2000's, covering a range of species groups. Since the late 1970s, most European countries have developed national or regional Red Lists to prioritise specific action and to enhance tree conservation. National Red Lists or Red Data Books of vascular plant species are available for the following countries: Albania (Government of Albania, 2013), Austria (Niklfeld \& Schratt-Ehrendorfer, 1999), Belarus (Kachanovskiy et al., 2015), Belgium (for Flanders; Van Landuyt et al., 2006), Bosnia and Herzegovina (Đug et al., 2013; Anon., 2012), Bulgaria (Petrova \& Vladimirov, 2009; Peev et al., 2015), Croatia (Nikolić \& Topić, 2005), Czech Republic (Grulich, 2012), Cyprus (Tsintides et al., 2007), Denmark (NERI, 2007), Estonia (Lilleleht, 2008), Finland (Rassi et al., 2010), France (UICN France et al., 2012), Germany (Ludwig \& Schnittler, 1996), Great Britain (Cheffings \& Farrell, 2005), Greece (Phitos et al., 1995), Hungary (Király, 2007), Iceland (Náttúrufræðistofnun Islands, 1996,; Náttúrufræðistofnun Íslands, 2008), Ireland (Wyse Jackson et al., 2016), Italy (Rossi et al., 2013), Latvia (Andrušaitis, 2003), Liechtenstein (Broggi et al., 2006), Lithuania (Rašomavičius, 2007), Luxembourg (Colling, 2005), Malta (Lanfranco, 1989), Moldova (Duca et al., 2015), the Netherlands (Van der Meijden et al., 2000), Norway (Henriksen \& Hilmo, 2015), Poland (Mirek et al., 2006), Romania (Dihoru \& Negrean, 2009), Russia (Trutnev et al., 2008), Serbia (Stevanović, 1999), Slovakia (Eliáš et al., 2015), Slovenia (Skoberne, 1996), Spain (Bañares et al., 2010), Sweden (ArtDatabanken, 2015), Switzerland (Moser et al., 2002) and Ukraine (Didukh, 2009). In addition, The Carpathian List of Endangered Species (Witkowski et al., 2003) assessed 
species at the level of the Carpathian region, but also assigned country-level Red List Categories for Austria, Czech Republic, Romania, Poland, Slovakia, Ukraine and Hungary. As with all Red List assessments, assessments need to be maintained and updated to remain relevant. The information on tree species from these national red lists have, when relevant, been incorporated into these European Red List assessments.

\subsection{Objectives and outputs}

The European Red Lists are reviews of the status of European species according to the IUCN Regional Red List guidelines (IUCN, 2012a). They identify those species that are threatened with extinction at the European level (Europe and the European Union) so that appropriate conservation action can be taken to improve their status. The objectives of this European Red List of Trees report are:
- To contribute to regional conservation planning through the provision of a baseline dataset.

- To identify the major threats to trees.

- To identify geographical areas and habitats needing to be conserved to prevent tree extinction.

- To inform, inspire and catalyse conservation action to prevent the extinction of European tree species.

The European Red List of Trees provides two main outputs: 1) This summary report on the status and distribution of the tree species that are native to the European region, their main threats and recommendations for conservation measures, and 2) the Red List assessments and distribution maps, which are freely available via two data portals, the IUCN Red List of Threatened Species ${ }^{T M}$ website (www.iucnredlist.org) and the EU European Red List portal (http://ec.europa.eu/environment/nature/ conservation/species/redlist). 


\section{Methods}

\subsection{Geographic scope}

The scope of these assessments spans the continent of Europe; from Iceland eastwards to the Ural Mountains in the Russian Federation, and south to the Mediterranean Sea. It includes Crimea, European Turkey, Cyprus and the European Macaronesian islands (Canary Islands, Madeira and the Azores) (Figure 1). In the southeast, the Caucasus region is excluded, as are some parts of the Russian Federation that are sometimes included within the European region; the Southern Federal District (e.g. Krasnodar Krai) and the North Caucasian Federal District.

\subsection{Global and regional assessments}

Species that are endemic to Europe were assessed on a global scale, including the full extent of the species. Regional assessments were carried out for those taxa with a distribution that extend beyond Europe, and are therefore not endemic to the European region. All species were assessed at two regional levels: 1) for geographical Europe (limits described above), and 2) for the area of the 28 Member States of the European Union. Through the duration of this project (2015-2018), the United Kingdom was an EU Member State.

\subsection{Taxonomic scope}

This project follows the IUCN/SSC Global Tree Specialist Group definition of a tree: a woody plant with usually a single stem growing to a height of at least two metres, or if multi-stemmed, then at least one vertical stem five centimetres in diameter at breast height. Some plant species have variable lifeforms, but all species that have been recorded as naturally growing as a tree were included.

The BGCI database of the world's tree species, GlobalTreeSearch (BGCI, 2017), was used to produce a

Figure 1. Map of European assessment boundaries including Europe and the 28 European Union Member States (EU 28).

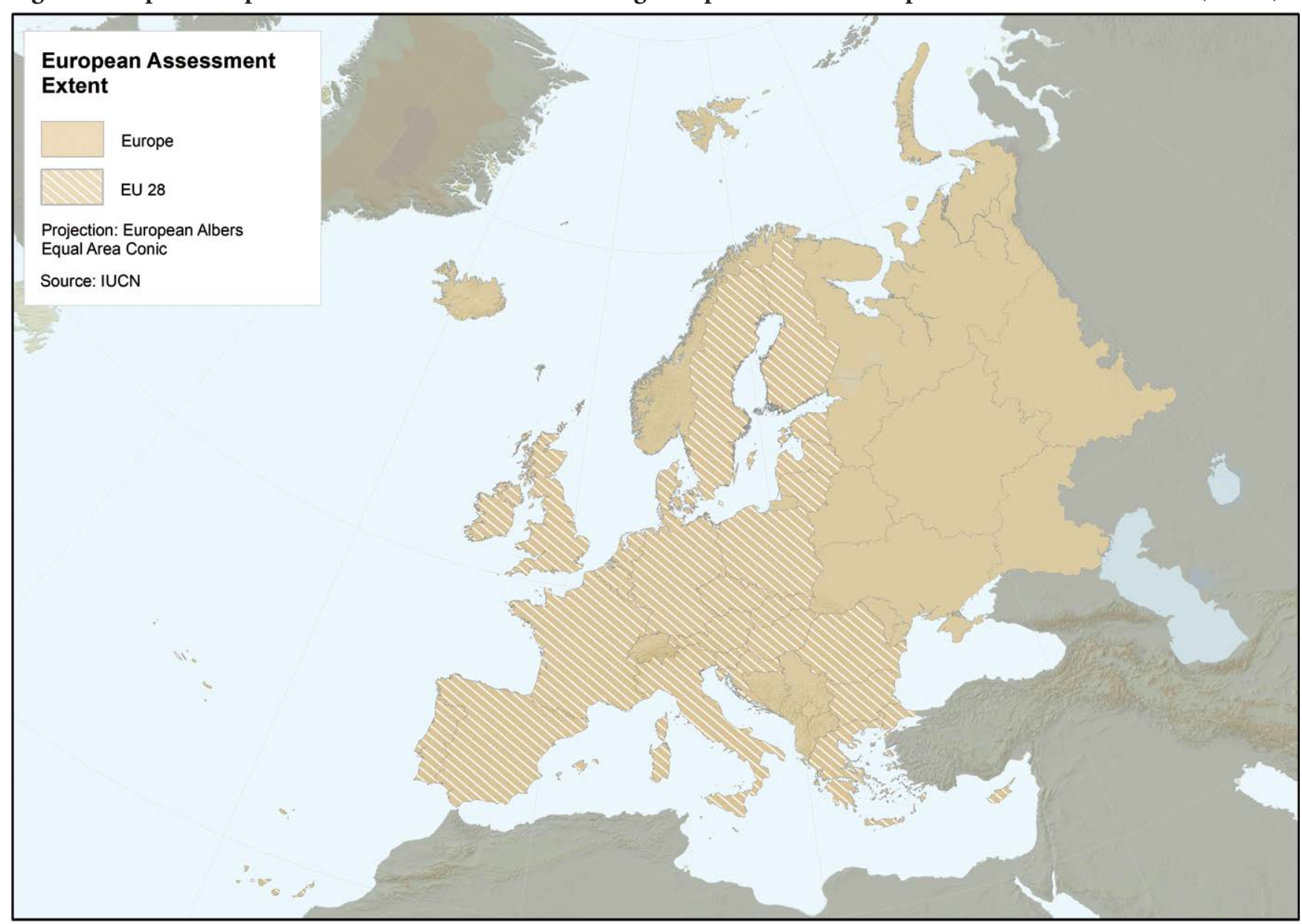


species list of trees for Europe. The taxonomic concepts used, follow a range of taxonomic and regional sources, including (but not exclusively) World Checklist of Selected Plant Families (WCSP, 2016), Flora Europaea (Tutin et al., 1964) and Euro+Med Plantbase (2006). Additional checklists and floras as well as taxonomic experts were also consulted where the taxonomy was unclear or where recent taxonomic changes had been suggested. For a full list of species included and assessed see Annex 1. Only species considered to be native to the European region were included and assessed. Newlydescribed taxa were included up until early 2017.

The conifers were, where required, assessed or reassessed in collaboration with the IUCN/SSC Conifer Specialist Group. Most non-coniferous species were assessed by BGCI and collaborators, with a small number of Mediterranean island-endemic species assessed by the IUCN/SSC Mediterranean Plant Specialist Group through its Top 50 Mediterranean island plants initiative. A selection of trees had been assessed previously by various other projects such as Crop Wild Relatives (Bilz et al., 2011), EU 'policy plants' (Bilz et al., 2011), medicinal plants (Allen et al., 2014) and specific taxonomic groups; i.e. Betulaceae (Shaw et al., 2014). All European tree species with an IUCN assessment published prior to 2010 were reassessed during this project whilst species with an existing assessment from 2010 onwards were not reassessed. Data were collated into the online IUCN Species Information Service (SIS) database maintained by IUCN.

\subsection{Assessment methods and process}

For each species, information was collected on its geographic distribution, population data and overall trends, its habitat and ecology, use and trade where applicable, threats, and conservation measures in place or required. Information for the assessments was collated from published and unpublished sources including floras, scientific papers, herbarium records, and expert knowledge and opinion. National red lists were consulted when available. For a full list of references used for each species, see the individual species assessment available online at the IUCN Red List website. A provisional Red List category was then assigned to each species based on the collated information using the 2001 IUCN Red List Categories and Criteria Version 3.1 (IUCN, 2012b), and for species not endemic to the European region, the assessment was revised where applicable using the

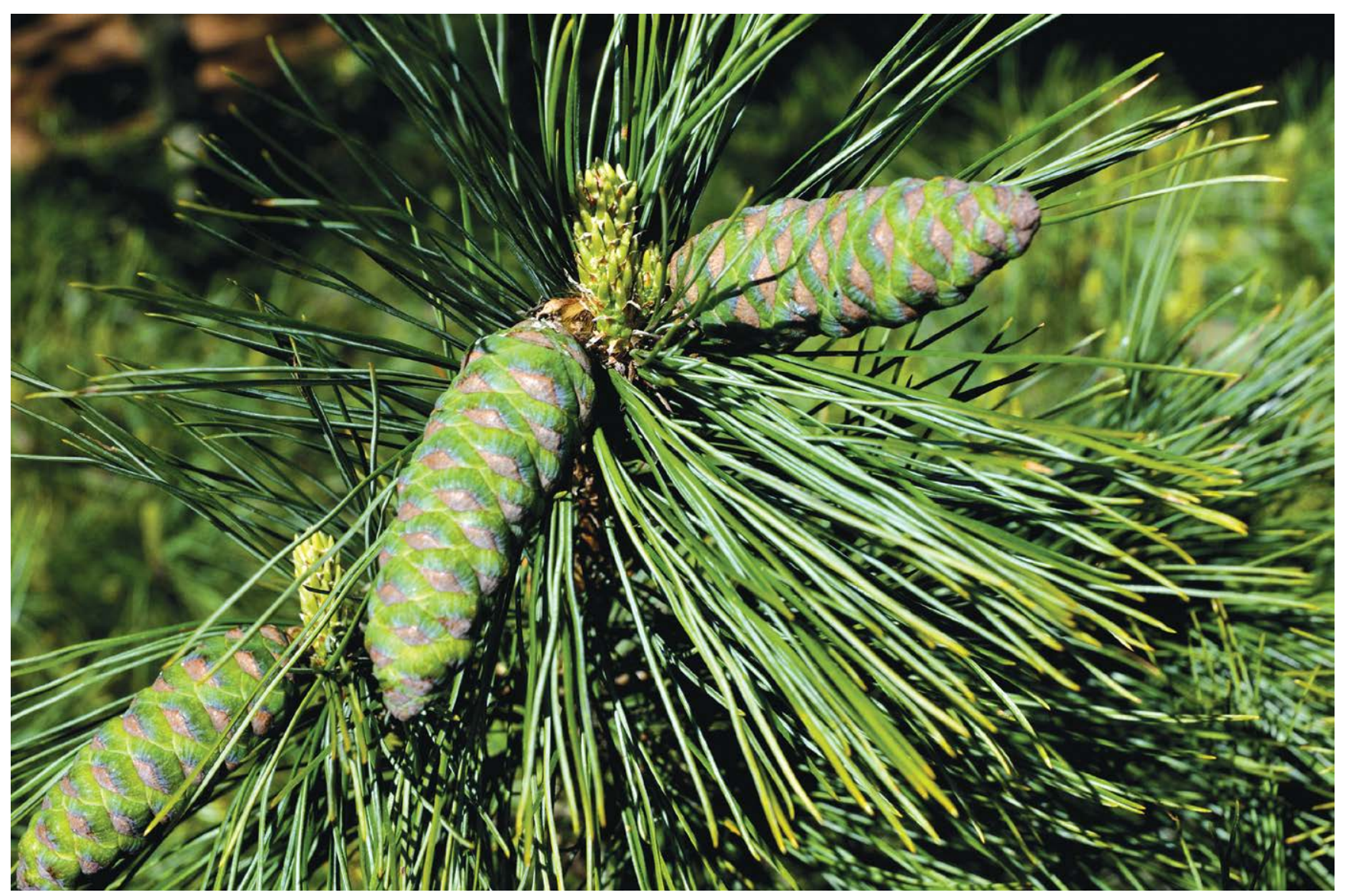

Balkan Pine Pinus peuce is a native endemic of the southern Balkan Peninsula It is assessed as Near Threatened for Europe, but as Vulnerable for the EU28 Member States, where it is restricted to northern Greece and western Bulgaria. (C) Aljos Farjon 
regional guidelines (IUCN, 2012a) (Figure 2). Species were assigned to one of the eleven categories: Extinct (EX), Extinct in the Wild (EW), Regionally Extinct (RE), Critically Endangered (CR), Endangered (EN), Vulnerable (VU), Near Threatened (NT), Data Deficient (DD) and Least Concern (LC), Not Applicable (NA), Not Evaluated (NE). See Annex 2 for a summary of the qualifying thresholds for each of the three threatened Red List categories.

\subsection{Spatial distribution maps and analyses}

Digital distribution maps were created using distribution data collated from available literature, internet sources, the Atlas Florae Europaeae (Kurtto et al., 2013), European Forest Genetic Resources Programme (EUFORGEN) species data, and the European Atlas of Forest Tree Species (San-Miguel-Ayanz et al., 2016; Caudullo et al., 2017). For some countries (and for some species), including Spain (Anthos, 2016), France (SILENE, 2017), UK (BSBI, 2017), Bulgaria, Sweden and Switzerland, distributions were available as either point location data (latitude/longitude) or in grid cell format. In addition, extensive use was made of the webbased GeoCAT Geospatial Conservation Assessment Tool (Bachman et al., 2011) to view and edit occurrence records held by the Global Biodiversity Information Facility (GBIF, 2017) and other sources, and to compile additional localities from literature or through workshops. Where point or grid data were available, data were projected in a Geographical Information System (GIS) (ESRI ArcMap) and polygons drawn manually, clustering points where appropriate. Depending on information availability, metadata coding was used to distinguish presence, origin, and seasonality across the spatial extent of a species' distribution. These codes differentiate the species presence (species are recorded as extant, possibly extant or extinct); seasonal presence of the species in the location (the default setting of 'resident' was assigned); and the origin of the species (native, introduced, reintroduced or uncertain). The coding information can be found in the Red List digital distribution metadata guidance (IUCN, 2014).

In the analysis of the spatial data, only distributions with the following Presence, Seasonal and Origin codes were used:

- Presence: Extant and Possibly Extant

- Origin: Native and Re-introduced

- Seasonality: Resident

Spatial data were analysed using a geodesic discrete global grid system, defined on an icosahedron and projected to the sphere using the inverse Icosahedral Snyder Equal Area (ISEA) Projection (S39). This corresponds to a hexagonal grid composed of individual units (cells) that retain their shape and area $\left(865 \mathrm{~km}^{2}\right)$ throughout the globe. These are more suitable for a range of ecological

Figure 2. The IUCN Red List Categories at the regional scale (version 3.1) (Source: IUCN, 2012a).

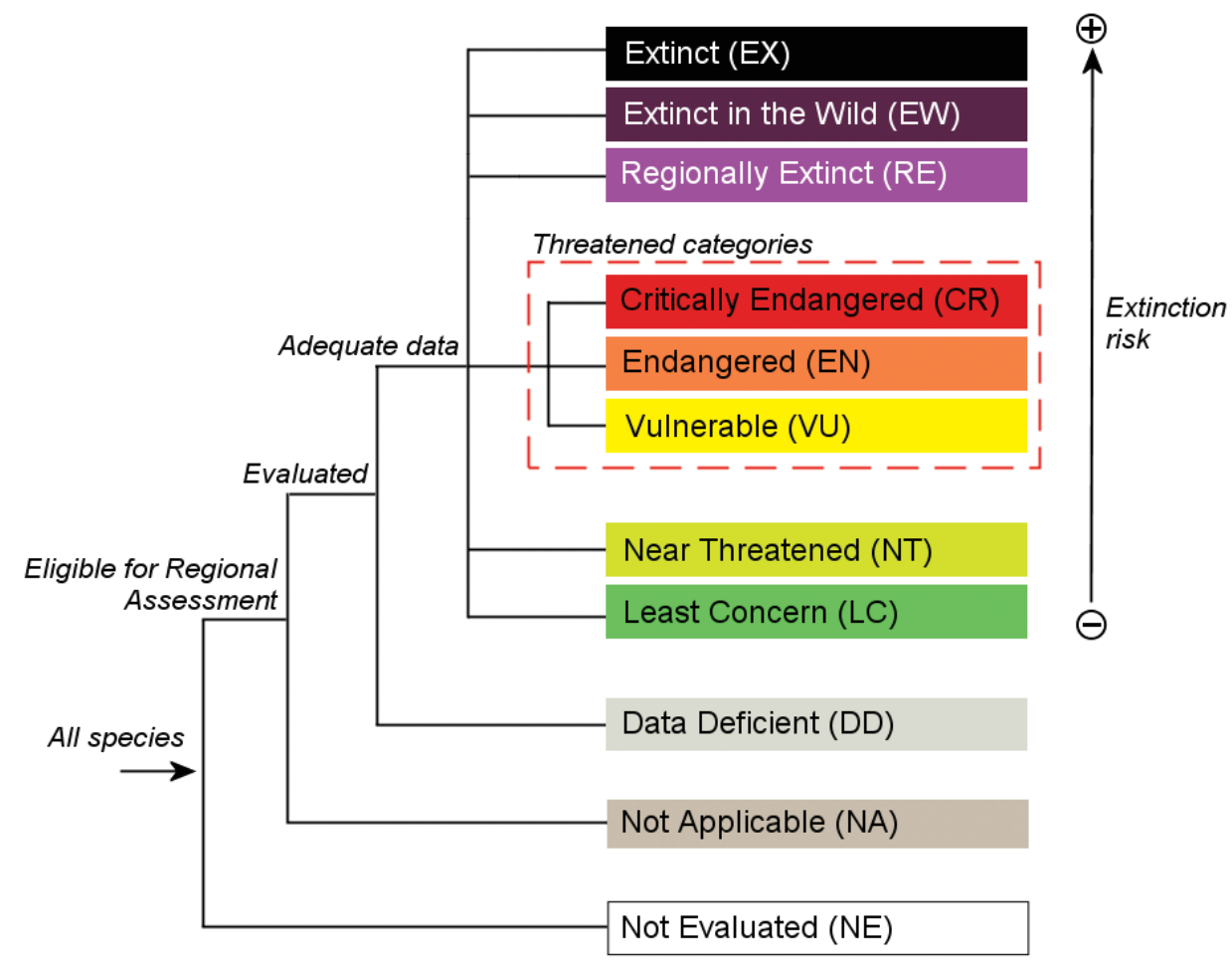




\section{Species profile: Horse-Chestnut - Aesculus hippocastanum}

Aesculus hippocastanum or the Horse-Chestnut tree, as it is more commonly called, is widely found across much of Europe but is in fact only native to Bulgaria, Albania, the mainland of Greece, and Republic of North Macedonia. This gives the species a large native range of 150,000 to $160,000 \mathrm{~km}^{2}$ but, despite this, the species is threatened (Allen \& Khela, 2017). National assessments consider the species Endangered in Bulgaria and Greece and Critically Endangered in Albania.

This iconic tree experiences a multitude of threats across its native range. In Bulgaria it is threatened by local tourism, pollution, wood extraction and forests fires which have caused the decline of the restricted subpopulation in the eastern part of the country. The species is similarly threatened within Albania; logging is of particular threat here as it occurs illegally and is centred on the old growth $A$. hippocastanum forests of the Pindus Mountains.

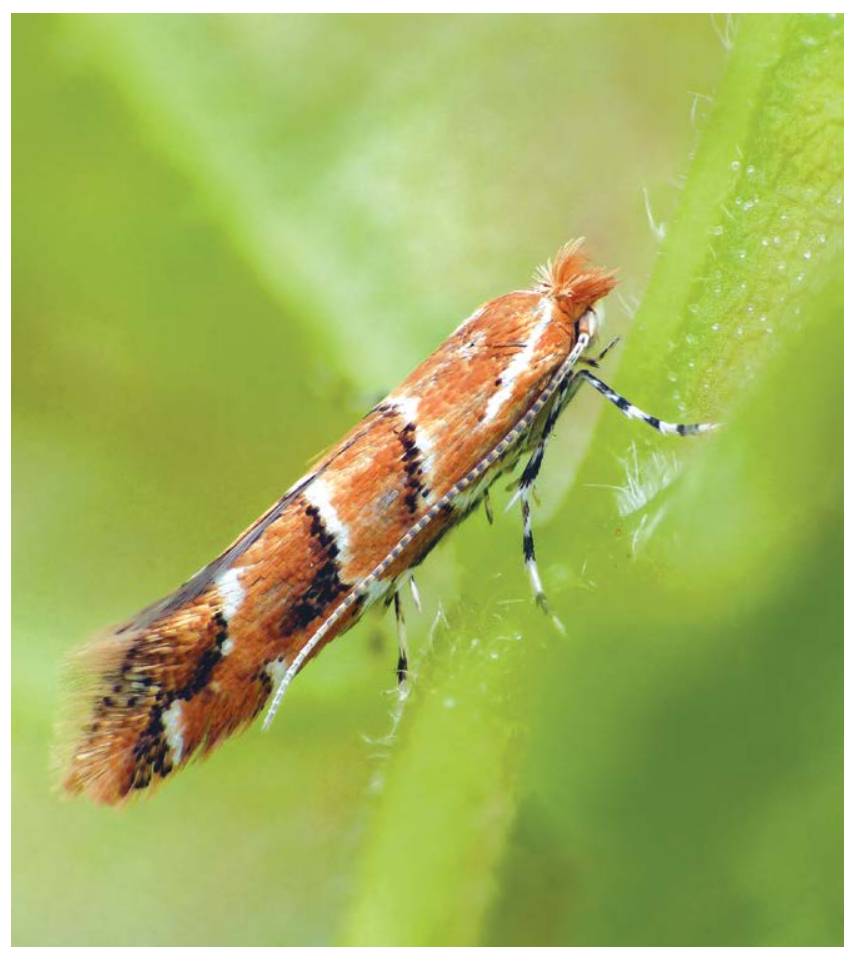

The Horse Chestnut Leaf-miner, Cameraria ohridella. (c) Patrick Clement (CC BY 2.0)

Across its entire range $A$. hippocastanum is threatened by defoliation by the leaf miner moth, Cameraria ohridella, an alien invasive. Infection by this pest has caused severe declines in population size as it reduces the survival and regeneration potential of the tree. The species is also affected by horse-chestnut leaf blotch caused by the fungus Phyllosticta sphaeropsoidea. This pathogen does not damage the tree but does cause its usually bright green, palmate leaves to become brown and blotched. Both these infections also affect the species in areas of introduction and cultivation where the species was originally grown as an attractive garden ornamental or street tree.

Within the species' native Balkan range, remnant populations preferentially grow within broad-leaf forest on rocky slopes and valleys, a habitat which itself is in decline. There is a growing incidence of landslides and collapse on these mountainous sites as they are developed for tourism and ecosystems are left out of balance due to clear cutting and soil erosion. The species is deservedly found within Nature 2000 sites and other protected areas within its native range. However, some of these are still adversely impacted by anthropogenic pressures; for example in the Iti National Park, Greece, mining still occurs.

These threats have left the remaining wild population of the species small and in continuing decline. Overall, it is estimated that the population is smaller than 10,000 individuals and no subpopulation is expected to contain more than 1,000 trees, causing the species to be assessed as Vulnerable C2a(i). Greece boasts the largest population of the species in its native range as population size estimates for Albania and Republic of North Macedonia are below 500 trees. Even so, within Greece the population has become scattered and only 1,500 mature individuals were found across 98 subpopulations.

Aesculus hippocastanum is a regionally important species of conservation concern. The species has been present within Europe prior to the last ice age. The species' spiked fruits are archetypal and the polished brown conker held within is perhaps more famous than the tree itself. This is due to their use for children's playground games. In Albania and Bulgaria conkers are used in folk medicine and have more recently been introduced into the pharmaceutical industry as they contain escin, which can be used to treat vascular problems (EMA, 2009). 


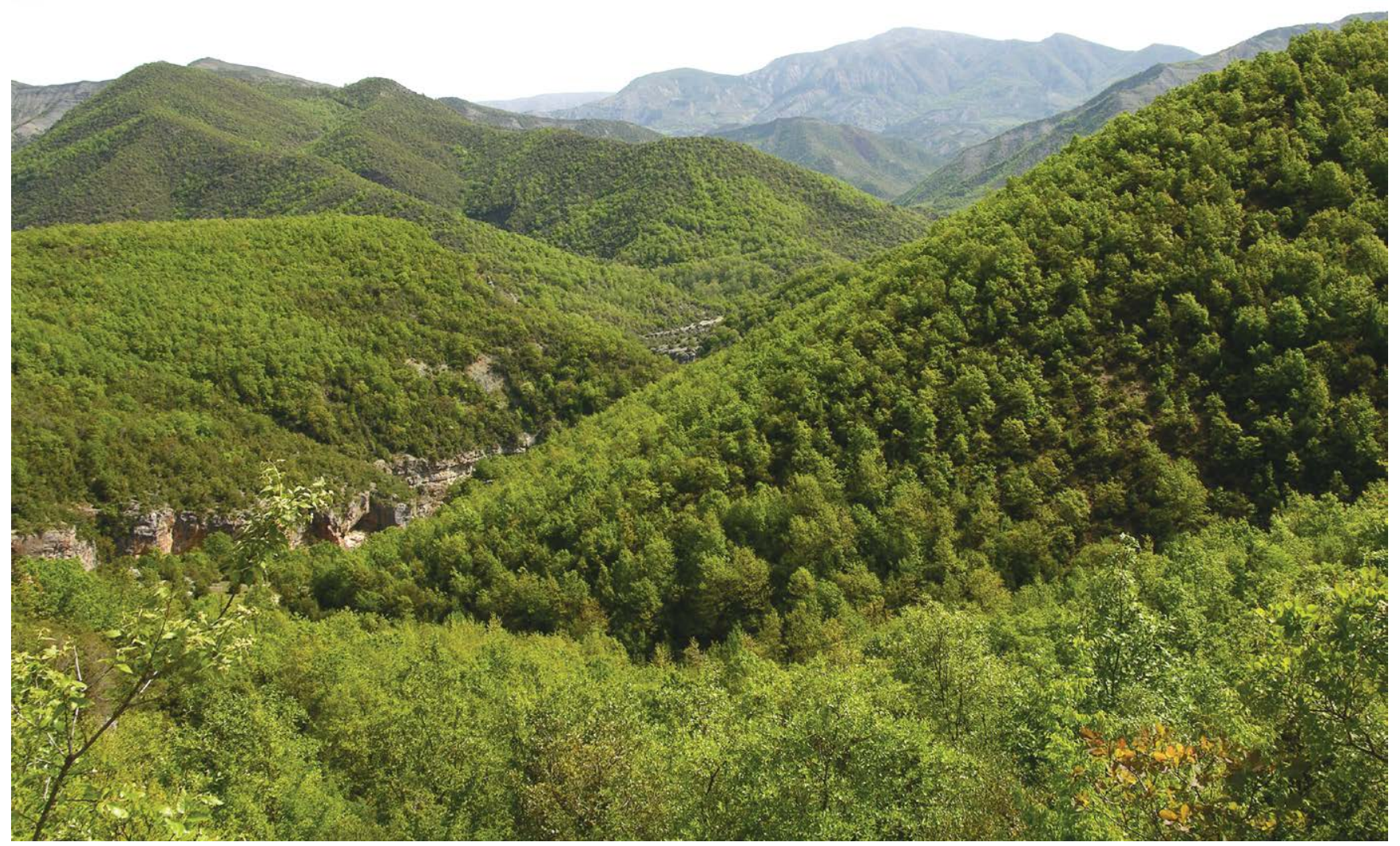

Mixed evergreen and deciduous forest (Carpinus orientalis) in southern Albania. ( ) Lulezim Shuka

applications than the most commonly used rectangular grids (S40). The range of each species was converted to a hexagonal grid for analysis purposes. Coastal cells were clipped to the coastline. The pattern of overall species richness (Figure 4a) was mapped by counting the number of species in each cell (or cell section, for species with a coastal distribution). Patterns of threatened species richness (Figure $4 \mathrm{~b}$ ) were mapped by counting the number of threatened species (categories Critically Endangered, Endangered, Vulnerable at the European regional level) in each cell or cell section. The pattern of endemic species richness was mapped by counting the number of species in each cell (or cell section for coastal species) that were flagged as being endemic to geographic Europe as defined in this study (Figure 4d). Finally, the distribution of species assessed as Data Deficient is shown in Figure 4e.

\subsection{Review of assessments}

Following production of the draft assessment and compilation of distribution data, the majority of the assessments underwent a process of peer review through assessment review workshops. The first review workshop (6-10 June 2016, hosted by The Botanical Garden of the Faculty of Science of the University of Zagreb, Croatia) focussed on European Sorbus species; the second workshop (10-14 October 2016, The Botanic Garden of the University of Pavia, Italy) on the remaining tree species of Europe, with a third workshop (23-24 January 2017; Jardin Botanico Canario "Viera y Clavijo", Gran Canaria) held on the Canary Island to review species endemic or near-endemic to the Canary Islands. A small number of species assessments were reviewed outside these workshops by direct consultation with experts with relevant geographical or taxonomic expertise.

The reviewed assessments then underwent consistency checks by the IUCN Red List Unit to ensure the global and regional IUCN Criteria and Guidelines were applied correctly. The IUCN assessments are the result of peerreviewed scientific consensus and are found online (www. iucnredlist.org). Sorbus assessments were published to the Red List in mid-2017, with the remaining assessments published in late 2017. 


\section{Results}

\subsection{Species selection and threat status}

In total, there are 454 species of native trees in Europe, found in 45 families. The most speciose family is Rosaceae, which has 216 tree species, the majority of which are from the genus Sorbus (see Case Study 1). In accordance with IUCN Red List guidelines, we have applied the species concept for both sexual and apomictic species. For a list of all the tree species in Europe with their conservation rating, see Annex 1.

Of the 454 European native tree species, 168 of the species are considered threatened in Europe (i.e. assessed as Vulnerable, Endangered or Critically Endangered, and therefore having an elevated risk of extinction). There are thirteen species (3\%) assessed as Near Threatened, almost meeting the criteria for a threatened category. A further 216 species $(47 \%)$ are considered Least Concern and therefore not of current conservation concern.

None of the trees were considered Extinct (or Extinct in the Wild, or Regionally Extinct). However, 57 species (13\%) were considered to be Data Deficient (DD), as insufficient information is available to assign a conservation status (Table 1). Due to the high number of Data Deficient species, the proportion of threatened species could be between $37.1 \%$ (if no DD species are considered threatened) and 49.6\% (if all DD species are considered threatened) for Europe (Table 2). The mid-

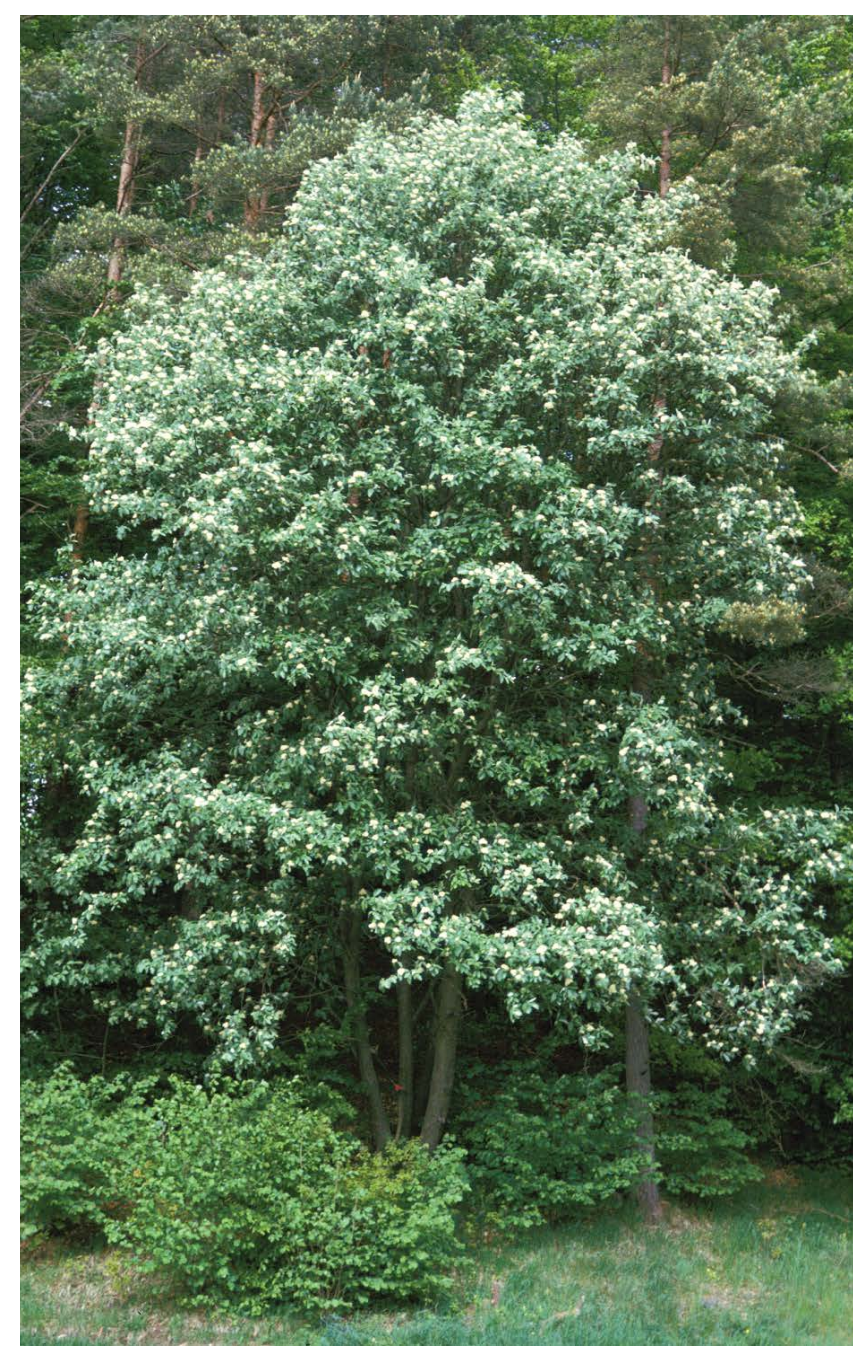

Sorbus cordigastensis (EN) is endemic to Bavaria in southern Germany. There are only 100 known mature individuals, and the species is threatened by forest management changes which encourage natural succession reducing the amount of available light. (C) Norbert Meyer

Table 1. Summary of tree species in each Red List category in Europe and the EU 28.

\begin{tabular}{lcc}
\hline IUCN Red List Category & $\begin{array}{c}\text { Tree species Europe } \\
\text { (endemic species) }\end{array}$ & $\begin{array}{c}\text { Tree species in EU 28 } \\
\text { (endemic species) }\end{array}$ \\
\hline Extinct (EX) & 0 & 0 \\
Extinct in the Wild (EW) & 0 & 0 \\
Regionally Extinct (RE) & 0 & 0 \\
Critically Endangered (CR) & $68(66)$ & $66(64)$ \\
Endangered (EN) & $62(58)$ & $57(53)$ \\
Vulnerable (VU) & $38(31)$ & $37(30)$ \\
Near Threatened (NT) & $13(7)$ & $10(5)$ \\
Least Concern (LC) & $216(67)$ & $207(66)$ \\
Data Deficient (DD) & $57(36)$ & $54(34)$ \\
\hline Total number of species assessed & $\mathbf{4 5 4 ( 2 6 5 )}$ & $\mathbf{4 3 1 ( 2 5 2 )}$ \\
\hline
\end{tabular}


Figure 3. Percentage of trees in each Red List category in a) Europe b) the EU 28.

a)

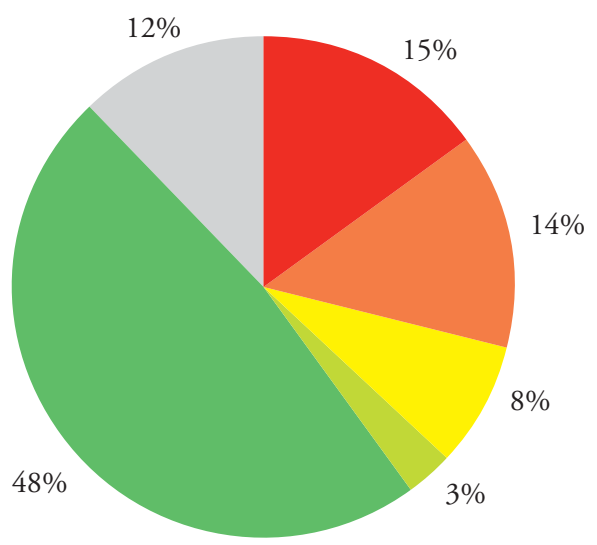

point value $(42.3 \%)$ provides the best estimation of the proportion of threatened species (IUCN, 2011). Of the 57 species rated as DD, $41(72 \%)$ belong to five genera of Rosaceae family: Crataegus, Malus, Prunus, Pyrus and Sorbus (Annex 1).

Almost all threatened species are endemic European trees; only thirteen threatened trees are non-European endemics. This means at least 58\% (155 species) of all endemic European trees are threatened (Table 1).

There is very little difference in the figures between Europe and the EU 28 assessments, the patterns are very similar (Figure 3, Table 2).

\subsection{Criteria used}

The majority of threatened species (72\%) were assessed under criterion D (Table 3), indicating a restricted population size. Forty percent of threatened species were listed under criterion B, threatened due to a restricted geographic range. It was only possible to assess 14 species using criterion $\mathrm{A}$ and $\mathrm{C}$, highlighting the difficulties in b)

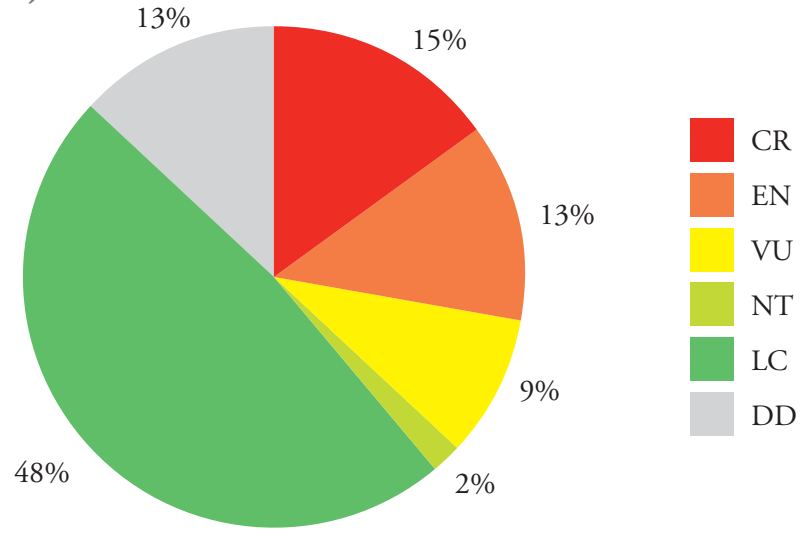

calculating population reductions for many tree species. This is in part due to their longevity, but also the result of the lack of monitoring data across the range over long enough time periods, and the difficulty in estimating generation time for many tree species.

The majority of threatened species (135 species, 80\%) were listed under a single criterion; 33 species (19\%) of the species were listed as threatened using multiple criteria.

Table 3. The IUCN Red List Criteria used for assessing the threatened trees at the European level and the percentage of threatened species assessed under each criterion.

\begin{tabular}{lc}
\hline Criterion & Number of species (\%) \\
\hline A & $4(2)$ \\
B & $68(40)$ \\
C & $10(6)$ \\
D & $121(72)$ \\
E & $0(0)$ \\
\hline Total & $\mathbf{1 6 8}$ \\
\hline
\end{tabular}

Table 2. Percentage of threatened trees in Europe and EU 28.

\section{Europe \% threatened trees $\quad$ EU 28\% threatened trees}

Lower bound

$(\mathrm{CR}+\mathrm{EN}+\mathrm{VU}) /($ assessed-EX)

Mid-point

$(\mathrm{CR}+\mathrm{EN}+\mathrm{VU}) /($ assessed-EX-DD)

Upper bound

$(\mathrm{CR}+\mathrm{EN}+\mathrm{VU}+\mathrm{DD}) /($ assessed-EX)
$37.1 \%$

$37.1 \%$

$42.3 \%$

$42.4 \%$

$49.6 \%$

$49.7 \%$ 


\section{Case study 1. Sorbus}

Tim Rich

Sorbus sensu lato is a genus of trees and shrubs that is widespread in the northern hemisphere. Jankun (1993) regarded Southeast Asia as the primary centre of origin, with three secondary centres of diversity in 1) the east Himalayas and China, 2) the Caucasus and Armenia, and 3) in Europe. Except a few widespread species, the European Sorbus species are found in single countries, with hotspots in the UK, Hungary, Germany, Czech Republic and the Balkans.

The genus Sorbus contains 170 tree species in Europe. Over three-quarters of these species are considered threatened: 57 species being Critically Endangered, 48 species being Endangered and 24 species being Vulnerable. Only 19 species of the more widespread species are Least Concern or Near Threatened. Information about status is very patchy in Europe mainly reflecting where work has been done recently, and too little is known about 22 species to assess them (Data Deficient).

The European Sorbus diversity arises from the unusual mode of reproduction which involves a combination of hybridisation, polyploidy and apomixis. The main lineages are genetically distinct but weak barriers to hybridisation between the species, combined with the isolating mechanisms of polyploidy and apomixis, has resulted in complex arrays of hybrids arising where species meet. Polyploidy is the occurrence of additional sets of chromosomes to the normal two (diploid) sets found in sexual species. In Sorbus there are five diploid species $(S$.

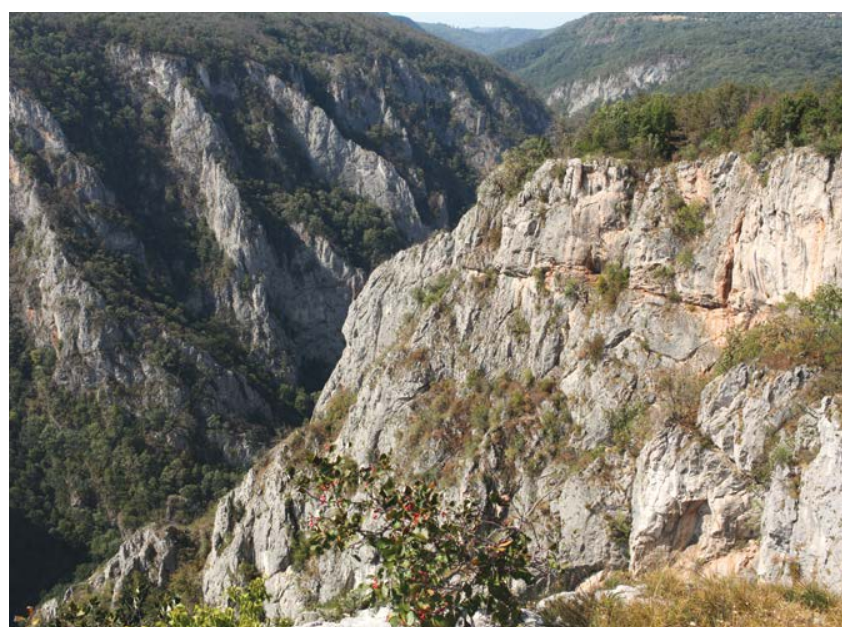

Sorbus hazslinszkyana (VU) from the Szádelői-völgy (Szádelői Gorge) in Slovakia. (C) Alexander Sennikov

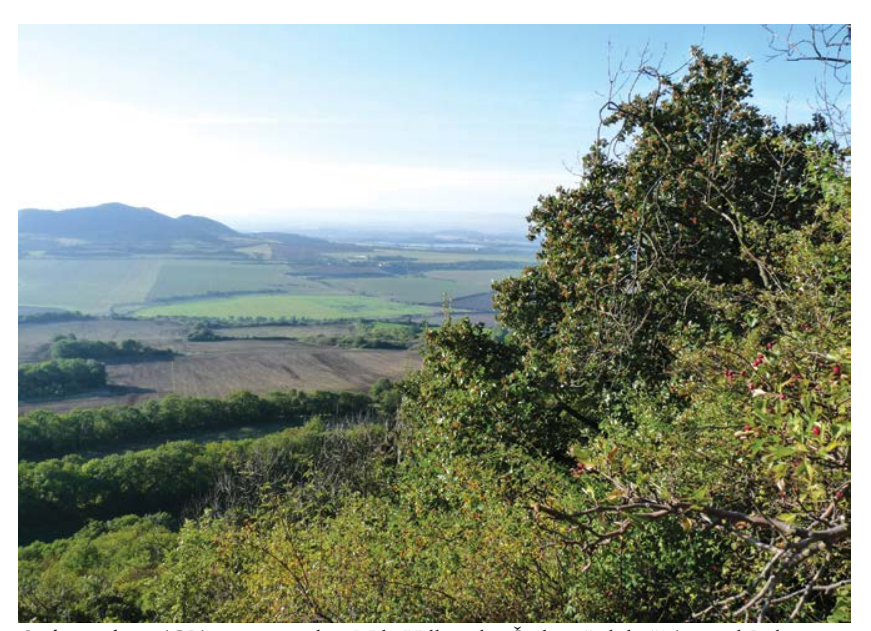

Sorbus milensis (CR) is restricted to Milá Hill in the České středohoří (central Bohemian Uplands) in northwestern Bohemia, Czechia. With only 38 mature individuals known, the species is threatened by low recruitment as well as grazing and competition from Fraxinus excelsior, reducing the habitat quality for this species. The entire known population occurs within the Milá Nature Reserve. (C) Martin Lep̌̌

aria, S. aucuparia, S. domestica, S. chamaemespilus and $S$. torminalis), and numerous species with three (triploid) or four (tetraploid) or rarely with five (pentaploid) sets of chromosomes. Apomixis is a form of asexual reproduction in which seed formation occurs directly from the tissue of the mother tree without any genetic input from the father and the seeds are direct clones of the mother, and apomixis is passed on genetically to the progeny. A further complication is pseudogamy, where pollination is required for development of the seed endosperm even if the pollen does not contribute to the genetic makeup of the seed. Recent studies (Ludwig et al., 2013) have shown that whilst some species are purely (obligate) apomictic others have occasional sexual events (facultative apomicts) which drives further speciation. This reproductive complexity has resulted in the origin of many new species where different parents have met during recolonization of Europe after the last glaciation and the process is ongoing today.

The main threats are from succession to tall woodland or deforestation, selective forestry, quarrying and grazing, and the small populations are often vulnerable. The small populations result from their recent origin and variable fertility, and they often have restricted habitats such as ungrazed, rocky cliffs as many are short, light-demanding trees which are palatable to animals. Lack of knowledge may also cause unnecessary losses. There is still much to do to conserve these beautiful little trees. 


\subsection{Spatial distribution of species}

\subsubsection{Overall species richness}

Figure $4 a$ highlights areas of particularly high concentrations of species. Not surprisingly, the highest numbers of species are found in the Mediterranean region and mountain areas such as the Balkan Peninsula, with further areas of high richness in the Crimean Peninsula. Such a distribution pattern of the tree species richness coincides with general distribution of plant diversity 'hotspots' and refugia in Europe (Médail \& Diadema, 2009; Svenning \& Skov, 2007; Svenning et al., 2010; Taberlet \& Cheddadi, 2002; Thompson, 2005).

\subsubsection{Distribution of threatened species}

The distribution of the 168 threatened taxa (those assessed as Critically Endangered, Endangered or Vulnerable) are shown in Figure 4b.

Of the threatened taxa, 130 are of the Sorbus genus (Figure 4c), showing a high concentration within Cheddar Gorge, southern Wales and north Cornwall in the United Kingdom, in parts of the Carpathians, and in Hungary.

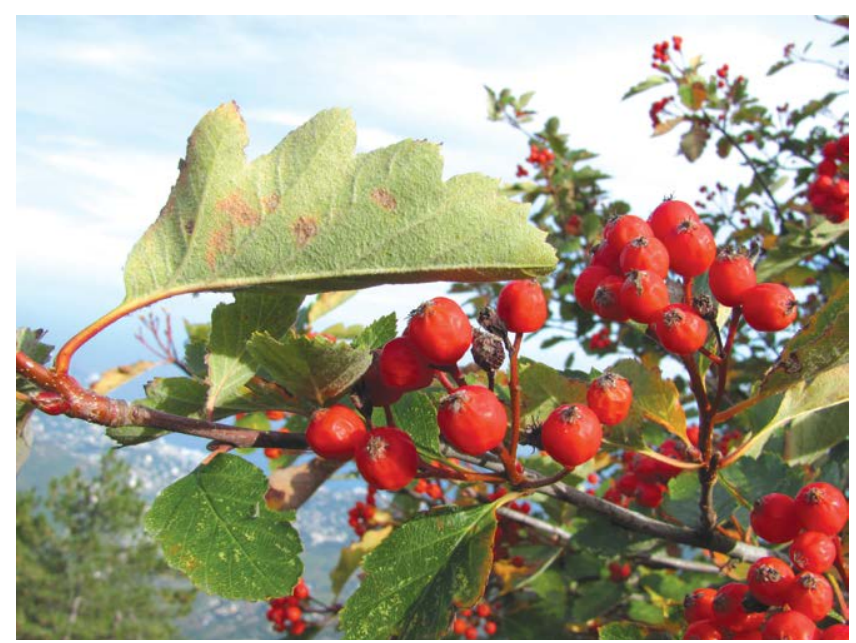

The Crimean Rowan Sorbus tauricola (EN) is endemic to the coastal mountains of southern Crimea, where it is threatened by regular and extensive damage to seeds by the wasp, Megastigmus brevicaudis, which prevents regeneration. (C) Alexander Sennikov

\subsubsection{Distribution of endemic species}

Two hundred and sixty-five species were found to have distributions restricted to Europe, (see Appendix 1). This information is presented visually in Figure $4 \mathrm{~d}$. In common with the results of several other European Red Lists (e.g. vascular plants (Allen et al., 2014; Bilz et al., 2011; García Criado et al., 2017), some of the highest levels of endemism are found in the main mountain

Figure 4a. The overall species richness of trees within Europe.

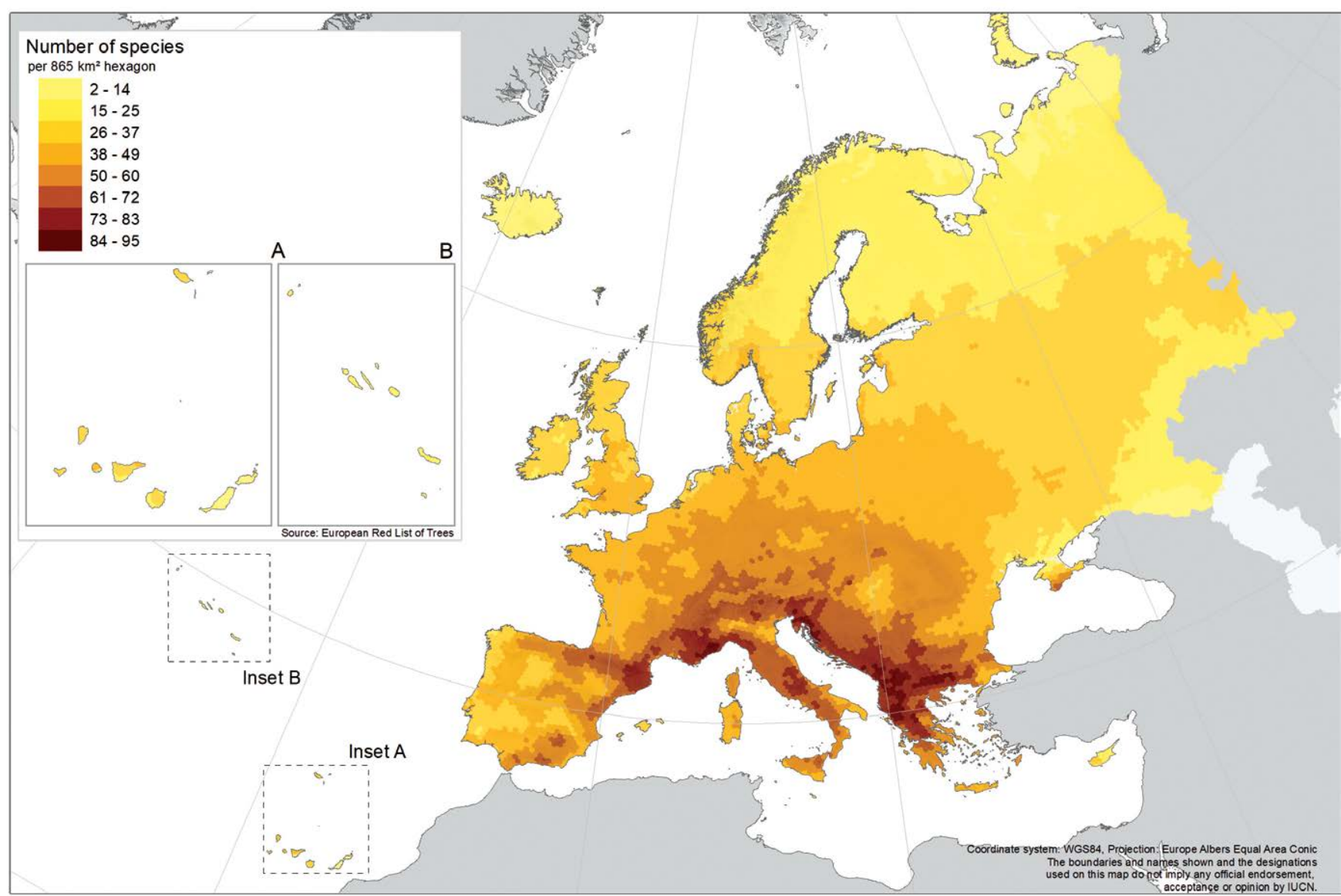


Figure 4b. The distribution of threatened (CR, EN and VU) tree species in Europe.

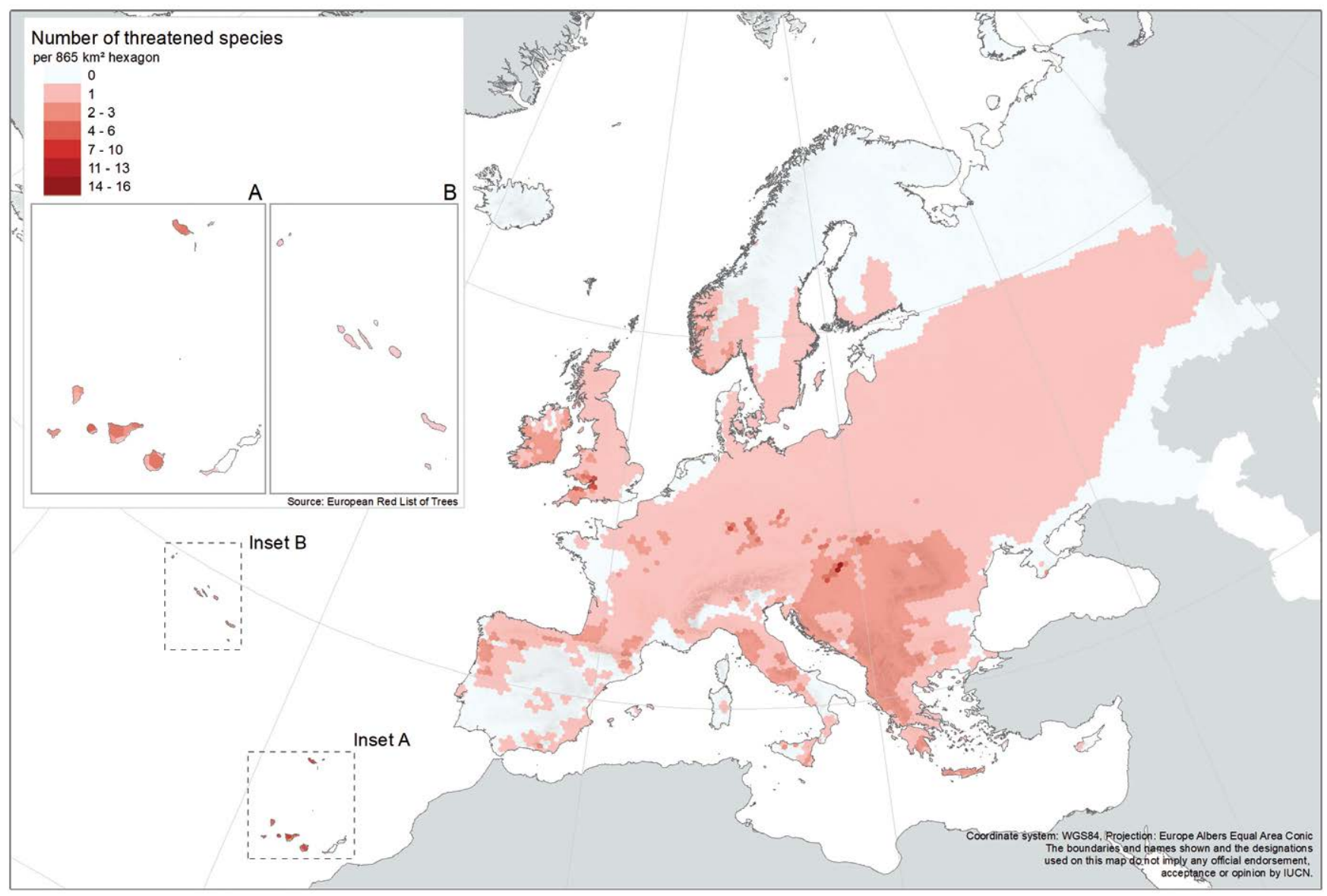

Figure 4c. The distribution of threatened Sorbus species in Europe.

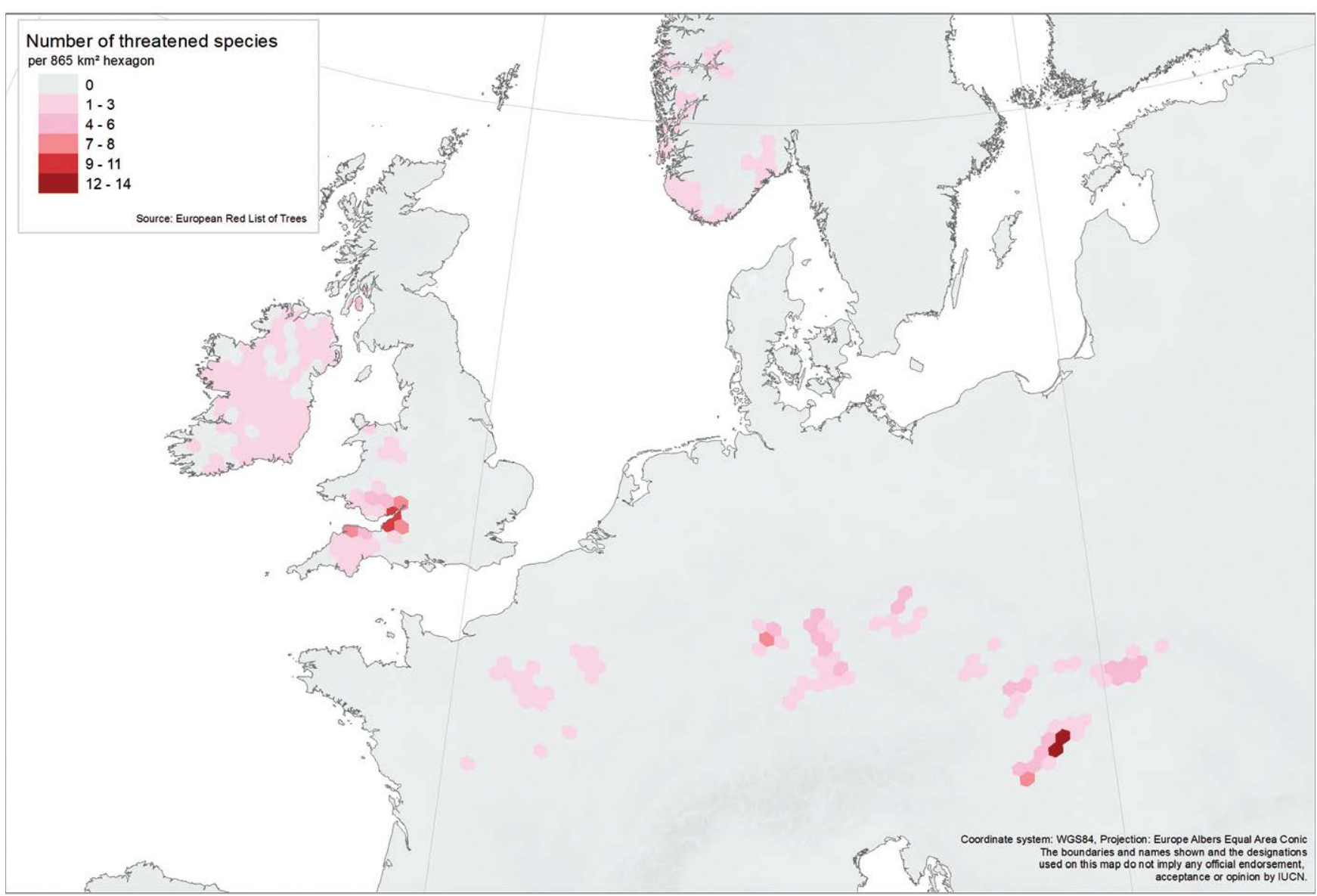


Figure 4d. The distribution of endemic tree species in Europe.

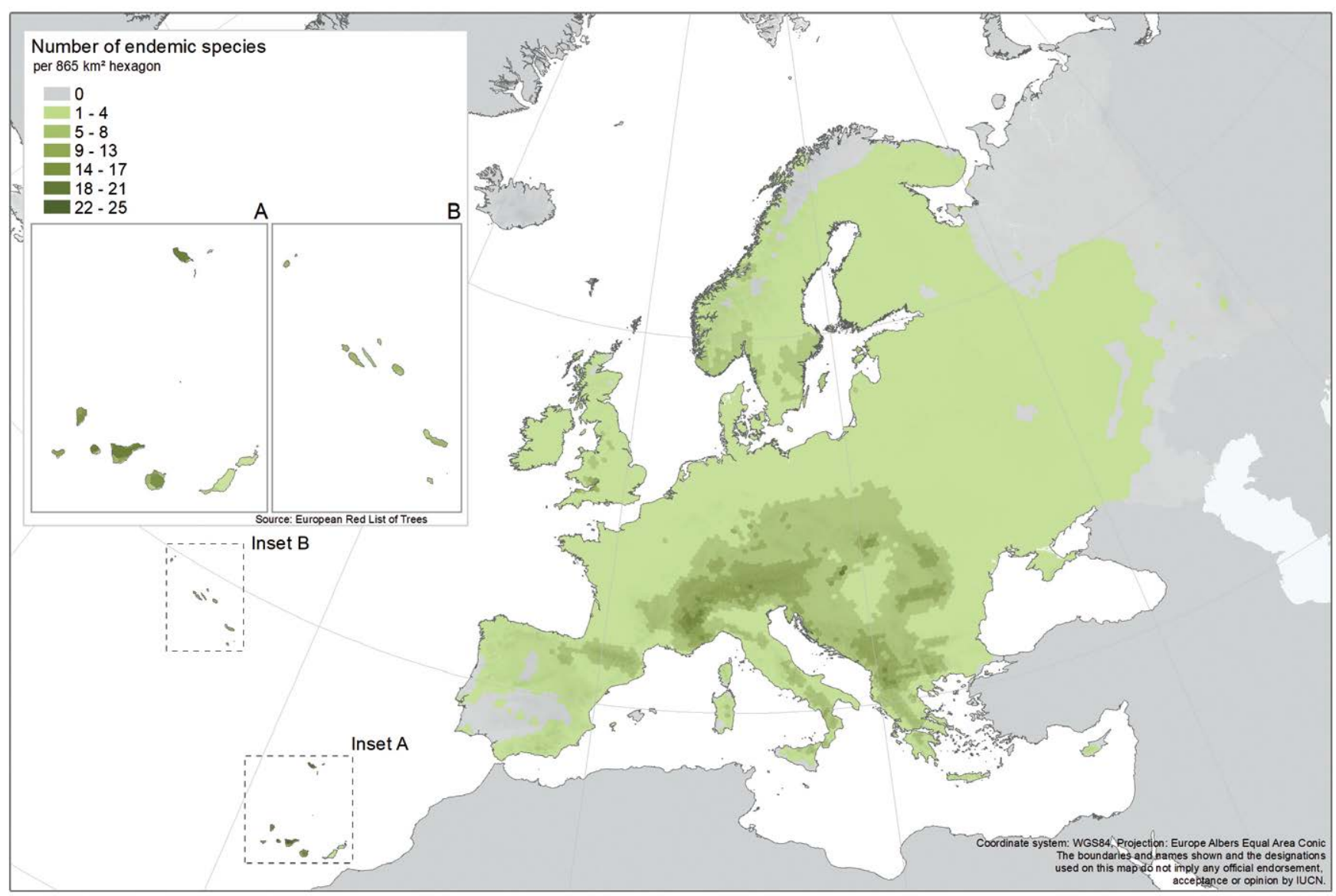

Figure 4e. The distribution of Data Deficient tree species in Europe.

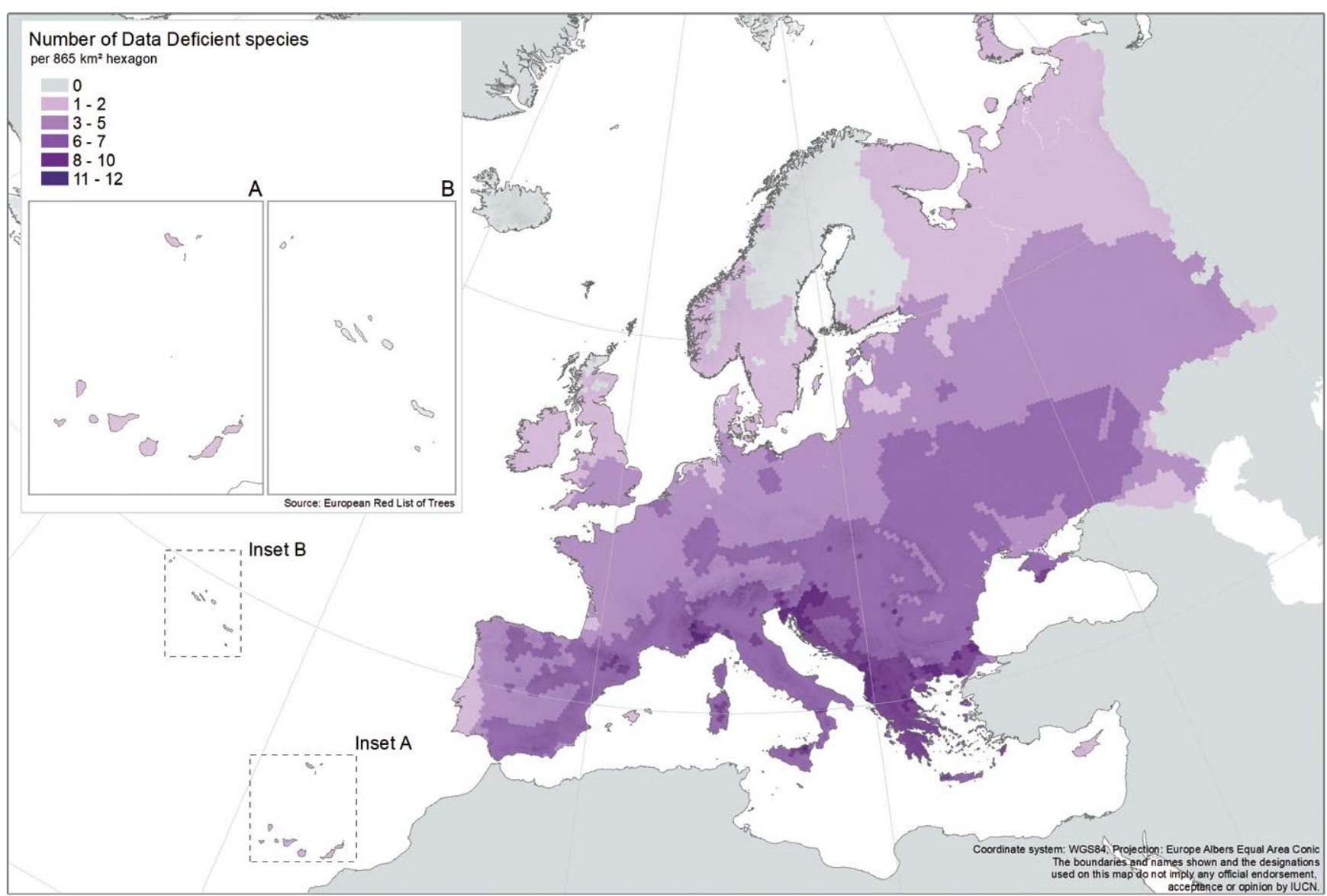




\section{Species profile: Heberdenia excelsa}

Heberdenia excelsa is a shrub or tree to 20 metres tall. It is native to all islands of the Canary Islands (except Lanzarote), where it most commonly grows as a shrub. The species is also present on Madeira and the islands of Desertas and Porto Santo. This gives the species a wide native range but an area of occupancy of only $304 \mathrm{~km}^{2}$.

This Macaronesian endemic can be found at high elevations in cloud forest where the environment is made more favourable by the trade winds and also on rocks and cliffs, while on the north-eastern coast of Tenerife the species occurs at lower elevations $(200-400 \mathrm{~m})$ in the remaining patches of thermophilous forest. The species also infrequently grows in the region's famous Laurisilva forests. Here individuals take a different morphological form to those in the thermophilous forest to the extent that some botanists would like them to be recognised as different species, but this will require further morphological and genetic analysis.
Heberdenia excelsa is assessed as Vulnerable. Although the total population is thought to exceed 3,000 individuals it is fragmented and scattered across many islands. Also, many of these subpopulations consist of only a single individual or low number of individuals.

The smallest subpopulations are found on Fuerteventura and El Hierro where the species is threatened by browsing from rats and goats. Elsewhere on the Canary Islands the population is in decline due to wildfires, landslides and both natural and anthropogenic-induced drought. The Madeira archipelago is home to an estimated 1,000 individuals of $H$. excelsa and these are broadly considered to be less threatened than the Canary island subpopulations.

Luckily the species is protected under law and found within many protected National Parks, as well as occurring within ex situ collections. Further conservation action will involve the monitoring of the Fuerteventura subpopulation and raising awareness of the species plight in this locality.

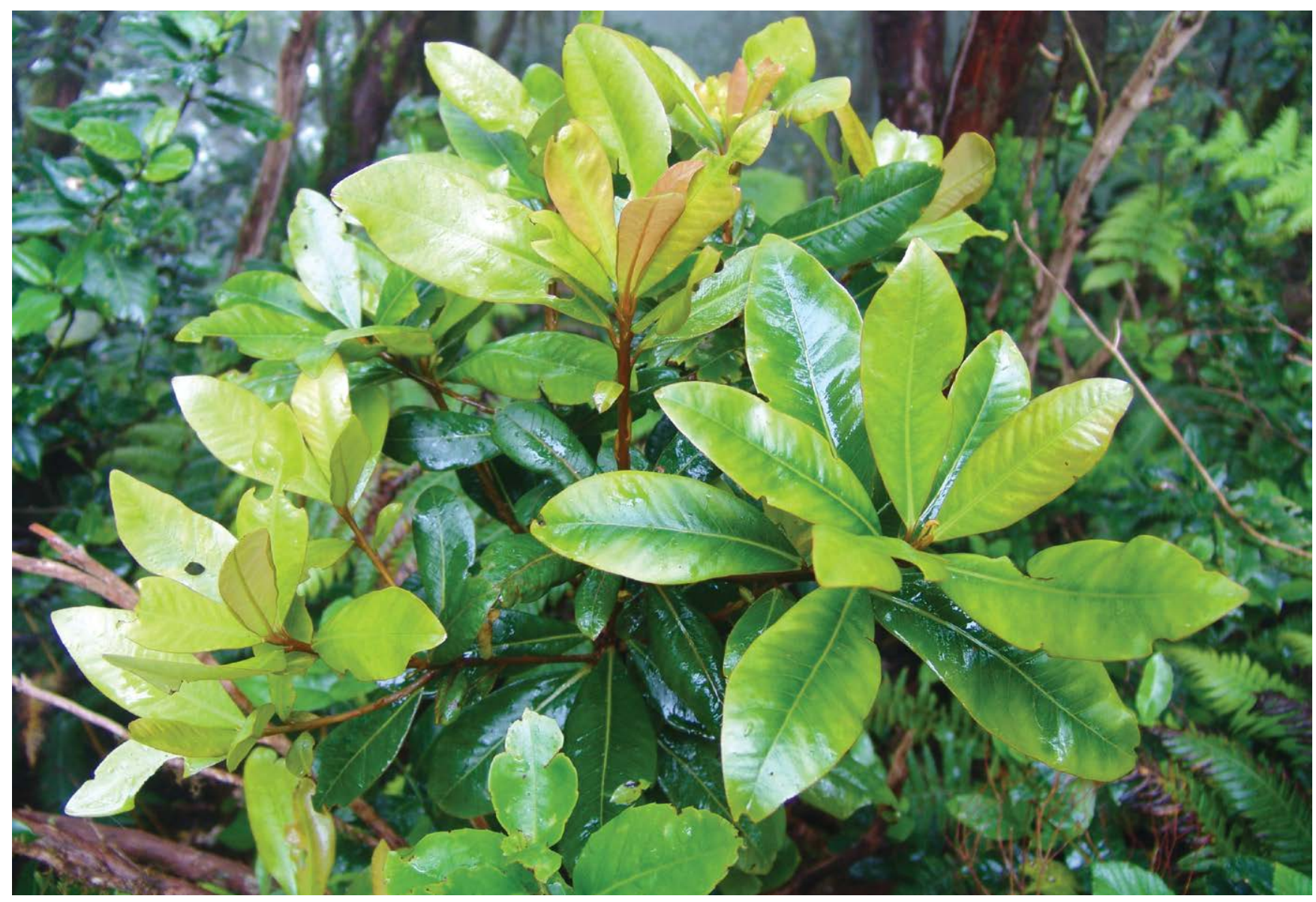

Heberdenia excelsa $(\mathrm{VU})$ is endemic to the Canary and Madeiran archipelagos. Although the species is relatively widespread, the subpopulations are affected by browsing by rats and goats, wildfires, and landslides. CDamián Esquivel Díaz (CC BY-SA 4.0) 


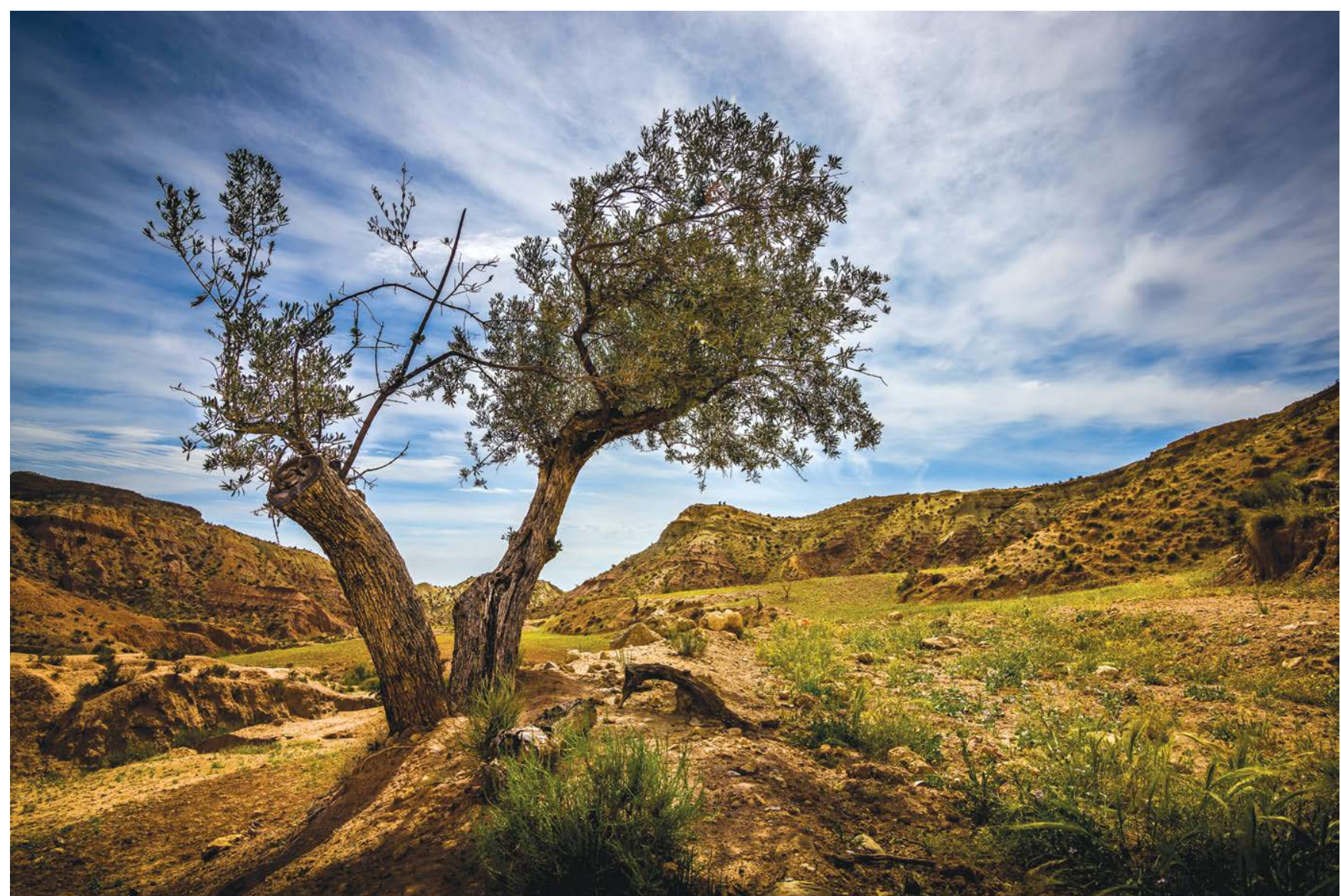

The Olive Olea europaea, shown here in the Tabernas Desert in Spain, is an example of a Data Deficient species. The Olive has been cultivated for thousands of years and as a result it difficult to know where the species is truly native and which individuals are truly wild, and nor do we know the impact that hybridization, between cultivated and wild trees, has had on genetic diversity. In recent years, the species has been impacted by Xylella fastidiousa, an introduced pathogen of American origin that has been associated with olive quick decline syndrome (OQDS) that was first recorded olive plantations in southern Italy but has now spread west to the Iberian Peninsula and to several of the larger Mediterranean islands. (C) Colin C. Wheeler (CC BY-SA 3.0 ES)

chains (Alps, Pyrenees, Carpathians, Apennines and through the Balkan Peninsula etc.) and Macaronesia. These areas represent centres of European plant species diversity and endemism that are floristically the richest areas in Europe (Horvat et al., 1974; Médail \& Quezel, 1997; Thompson, 2005).

\subsubsection{Distribution of Data Deficient species}

Patterns of Data Deficient (DD) species (figure 4e) follow those for the overall species richness, i.e. through mountain areas, the Balkan Peninsula, southern Italy and the northern and southern Iberian Peninsula. The distribution of Data Deficient species highlights those areas where more research is needed in order to confirm the extinction risk of the species. In most cases, species were considered Data Deficient because of a lack of data on their distribution, or because of taxonomic uncertainty and confusion with similar taxa, again resulting in an uncertain distribution, whilst some species were considered DD because they have been described only very recently and little is known of them. As not all DD species can be mapped, figure 4e only provides a partial picture of the distribution of DD species.

\subsection{Major threats to European trees}

As part of the assessment process the major threats to European trees were identified and recorded (Figure 5). The main threat to tree species in Europe is identified as invasive or problematic species, impacting $38 \%$ of tree species, followed by deforestation and wood harvesting and urban development (both affecting 20\% of tree species). For threatened species, livestock farming and land abandonment and other ecosystem modifications is a major threat, impacting the survival of trees.

For 61 of all tree species (13\%) the major threats remain unknown and for 58 species there are no current major threats.

\section{Alien invasive and problematic species}

Alien invasive or problematic native organisms are the most severe threat to trees in Europe (Rejmánek \& Richardson, 2013; Seebens et al., 2017). This category of threat includes: 


\section{Box 2: Alien invasive tree species in Europe}

The introduction of non-native tree species is widespread in Europe. Since the first introductions of alien (nonnative, exotic) tree and shrub species to Europe over 200 years ago, more than 130 species, mostly from three families (Rosaceae, Fabaceae and Pinaceae) have become established (Rejmanek \& Richardson, 2013). Most of these species have been intentionally introduced for ornamental or forestry purposes, but also for erosion control, agro-forestry and fuelwood (Rejmanek \& Richardson, 2013; Brundu \& Richardson, 2016). Examples include the Douglas Fir (Pseudotsuga menziesii), the Sitka Spruce (Picea sitchensis) and Eucalyptus species.

While most alien tree species have not spread outside of plantation sites and are therefore currently not considered invasive, a significant number of alien tree species are widely considered to be invasive, such as the Black Locust (Robinia pseudoacacia) or the Tree of Heaven (Ailanthus altissima) (Medina-Villar et al., 2015; Vítková et al., 2017).

As with invasive alien species of other taxonomic groups, invasive alien tree species can have strong negative impacts on ecosystem services, native communities and native species richness. The Boxelder (Acer negundo) from the Americas, for example, is highly invasive in riparian forest habitats in southern and Eastern Europe. Its high phenotypic plasticity (e.g. growth rate) supports its ability to outperform native tree species (Porté et al., 2011).

In 2014, the Regulation (EU) No. 1143/2014 on the prevention and management of the introduction and spread of invasive alien species was enacted to mitigate the increasing threat of biological invasion. In order to implement general principles of prevention and risk, the Council of Europe has supported the establishment of a Code of Conduct on Planted Forest and Invasive Alien Trees (Brundu \& Richardson, 2015).

i. Pests and diseases that cause major declines to some of our more widespread tree species across Europe with devastating effects (see further discussion in Case Study 2);

ii. Grazing of seedlings, clones and regeneration by non-native animal species, such as goats and deer, which significantly reduce the capacity for natural regeneration;

iii. Alien invasive plants (Box 2) pose the problem of competition as they are often fast-growing species that outcompete native tree seedlings by restricting light availability and other resources (especially on islands, see Case Study 3);

iv. Hybridisation is also identified as a threat for some species (such as Populus nigra, Ulmus minor), which has led to difficulties in identification of natural populations and loss of local genotypes.

\section{Deforestation, degradation and wood harvesting}

Some European tree species are directly harvested, both for their timber and for other non-wood products, and some of this harvest comes from plantations. However, logging not only impacts the targeted species, but also indirectly affect the species relying on the forest habitat. These non-target impacts can be significant, especially for range-restricted species such as Rhamnus persicifolia and Zelkova sicula (both CR) from Sardinia, and Gesnouinia arborea (EN) from the Canaries.

Livestock farming is a primary driver of the conversion of forests and woodland to agriculture. These habitats are sometimes clear-felled to make land available for farming, whilst extensive livestock farming can also impact tree populations as grazing can decrease the number of seedlings surviving to maturity.

\section{Climate change}

Severe impacts on biodiversity arise from climate change but are often uncertain and may be underestimated (Lindner et al., 2014) and these impacts require research and specific actions of conservation in relation to conventional approaches (Shoo et al., 2013). We consider climate change to be a potential threat to all species of tree within Europe, however we have included impacts of climate change in the Red List assessments only for species where the potential impact on an individual species has been clearly documented, but for the vast majority of species the effects of climate change have yet to be quantified, although the potential impacts have been modelled by a number of authors (e.g. Barredo et al., 2017; Spinoni et al., 2017; de Rigo et al., 2018). 


\section{Case study 2. Pests and diseases}

Ellie Barham and Katherine O’Donnell, International Plant Sentinel Network

Plant pests and diseases pose a significant threat to tree species in Europe and the rest of the world. The majority of harmful organisms are invasive, non-native species whose introduction causes harm to the ecosystem. These organisms often have a large impact due to a lack of natural enemies in their introduced regions and a lack of evolved resistance from native host trees. In 2014 alone, 200 outbreaks were recorded across Europe of organisms that were known to be harmful to plants and were not (yet) considered widespread throughout the region (European Commission, 2015).
The threat from these organisms is ever-growing, largely as a result of the increase in the globalisation of trade (particularly that of live plants) which creates new pathways for the introduction of such harmful organisms (Liebhold et al., 2012). However, climate change also plays its part (Seidl et al., 2017), expanding the amount and range of suitable habitat available allowing the spread of such organisms to new regions. Where previously an introduced pest or disease would die out due to unfavourable conditions, changes to the climate create a suitable environment which is able to sustain the organism. In addition, changes in climate will also exact stress upon trees (such as changes in temperature and precipitation, extreme weather events etc.), which increases their susceptibility to harmful organisms. This weakening of a tree can also impair the ability to fight

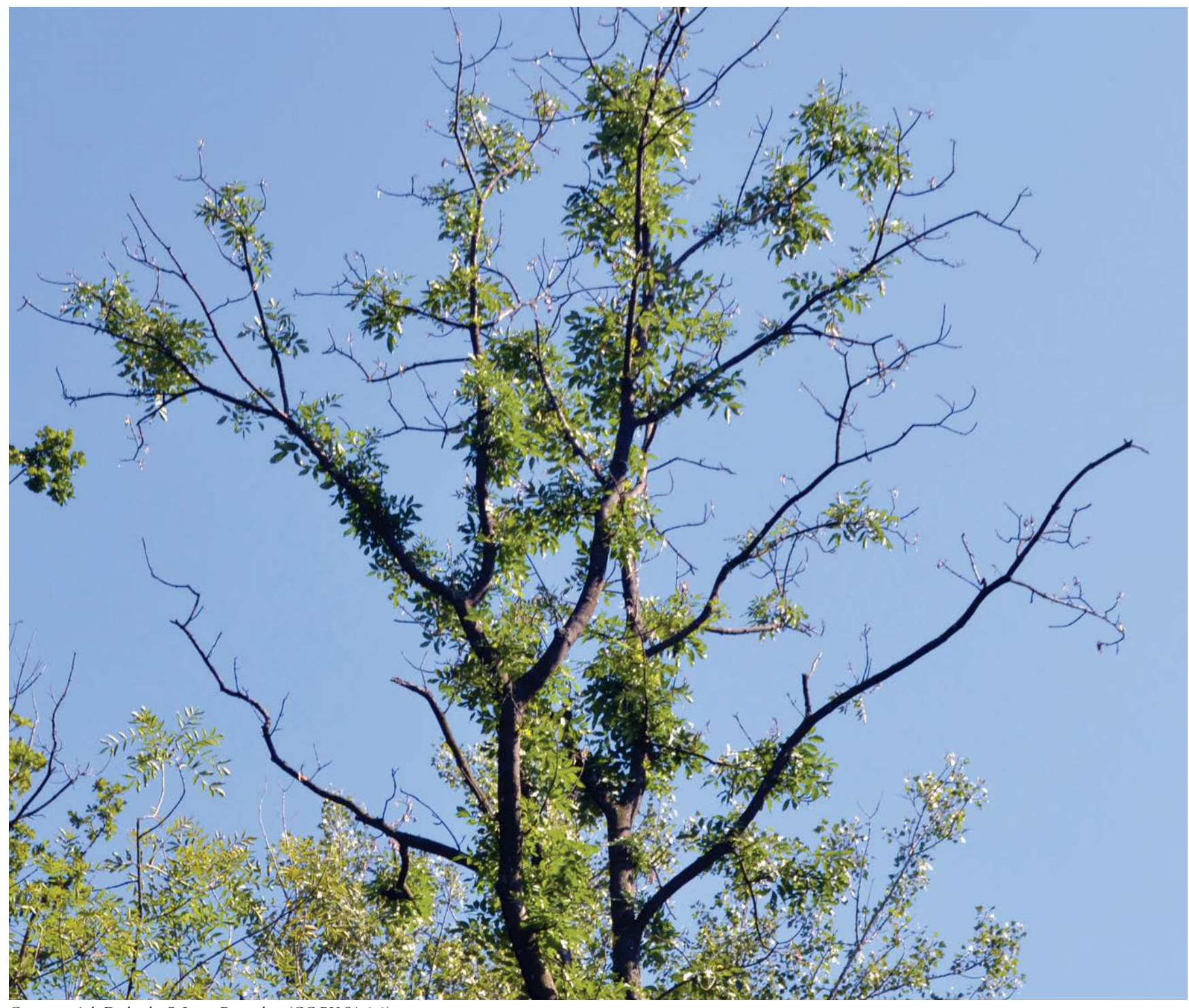

Common Ash Dieback. (C) Jonas Barandun (CC BY-SA 3.0) 


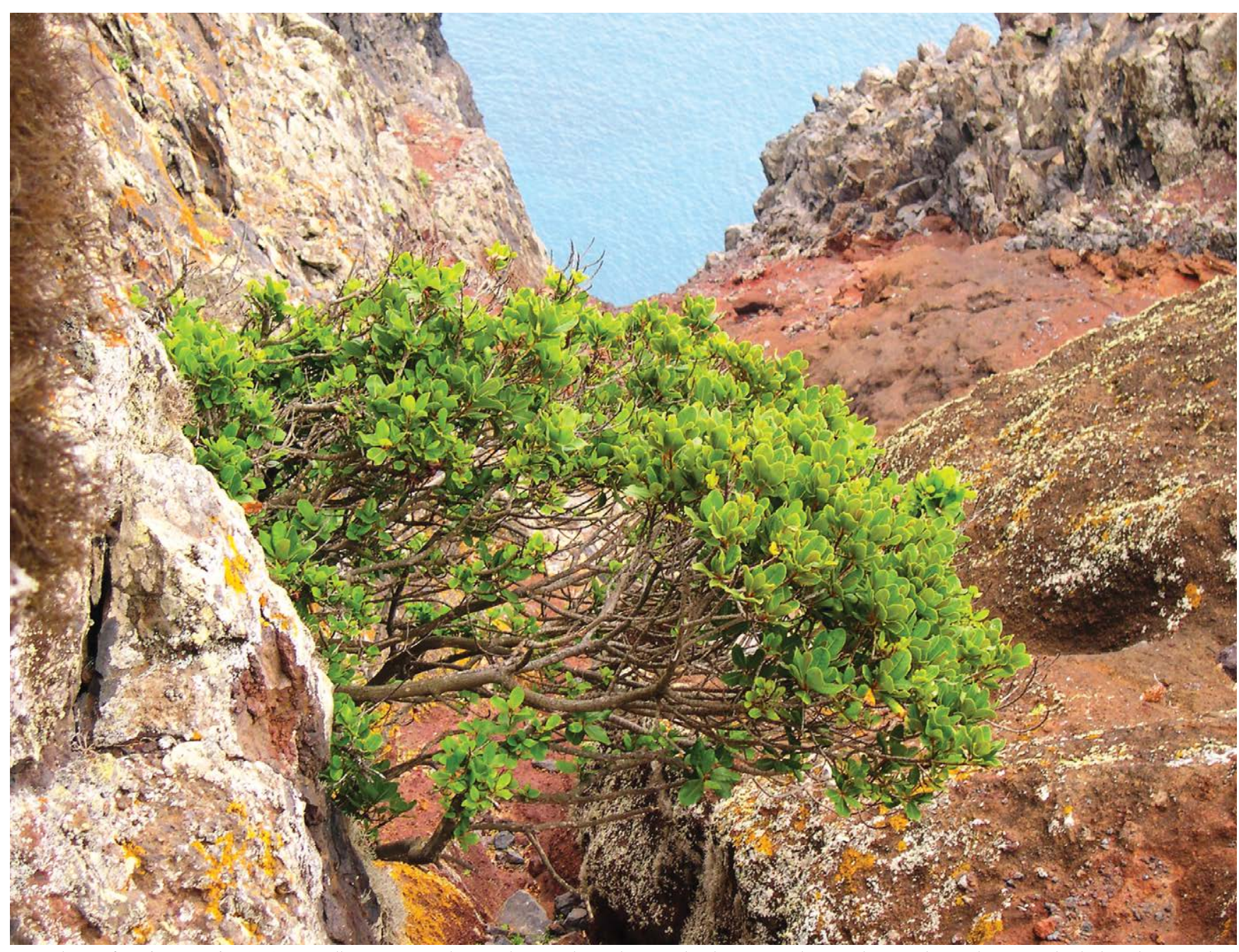

Marmulano Sideroxylon mirmulans (EN) is a small evergreen tree that is endemic to the Madeiran Archipelago, Portugal. Fewer than one thousand mature individuals are known and the species is impacted by a range of threats that include urban development and competition with invasive species. (C) Carlos Viveiros

against infections and damaging symptoms, which they may have been capable of historically. This can result in a shift in status of native organisms from a negligible to a major pest (Tubby $\&$ Webber, 2010).

In Europe some of the more widespread species of trees are also impacted so severely by plant pests and disease that they can cause widespread and common species to qualify for a category of threat (Vulnerable, Endangered and Critically Endangered). Several examples exist where previously widespread species are now suffering due to new pests and diseases. The Dutch Elm disease in the 1970s has led to a severe decline in species of Ulmus (Caudullo \& de Rigo, 2016). A more recent outbreak of Common Ash Dieback has also led to a concern to the rapid declines of Fraxinus excelsior (Pautasso et al., 2013; Stocks et al., 2017), increasing its risk of extinction.

In an attempt to better monitor and detect risks, the International Plant Sentinel Network (IPSN) has been set up to provide an early warning system to identify new and emerging pest and pathogen risks. It works via a network of both national and international partnerships between government bodies such as National Plant Protection Organisations (NPPOs), plant protection scientists and botanic gardens and arboreta. Botanic gardens help to provide scientific evidence regarding known quarantine organisms and potential new risks to native and horticulturally important plants. This information is used by NPPOs to support plant health activities such as Pest Risk Analysis (PRAs) and management. The IPSN provides an opportunity for botanic gardens to build on their research and conservation efforts by helping to safeguard plants from damaging organisms. 


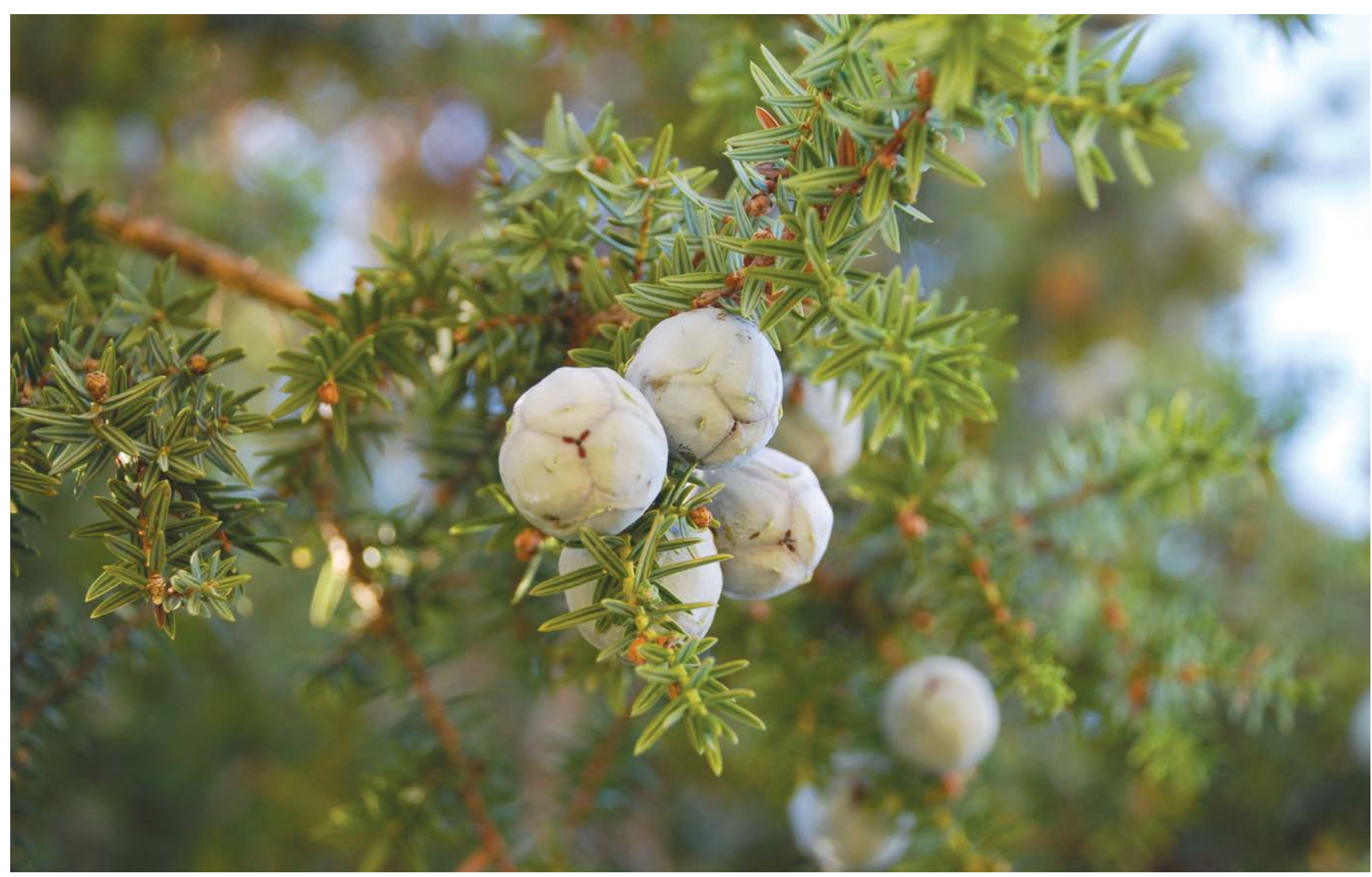

In Europe, the Syrian Juniper Juniperus drupaceae is restricted to the Peloponnese Peninsula in Greece, where both the extent of occurrence and the area of occupancy are restricted. The species is assessed as Endangered because there are ongoing threats from fire and over-grazing. (C) Magda Bou Dagher / www.lebanon-flora.orgar

It is important to note that land use change, changes in fire frequency and intensity, and climate change are often interrelated threats, with potential for significant feedback between them (Pausas \& Fernández-Muñoz, 2012; Gallardo et al., 2016; Doblas-Miranda et al., 2017; de Rigo et al., 2017).

\section{Land abandonment and other ecosystem modifications}

Changes in land management practices have led to negative impacts on tree species, especially when traditional management practices in semi-natural woodlands, meadows and heathlands are abandoned. For many lightdemanding species that have evolved to survive in these environments, abandonment of traditional practises is decreasing the availability of habitat and impact recruitment. This is a key threat identified for many of the threatened Sorbus species (see Case Study 1).

\section{Urban development}

Urban, tourism and industrial areas are expanding into previously natural or semi-natural habitats reducing the area available for many species. Trampling, increased erosion and increased access in certain sensitive habitats may impact survival. Also, infrastructure, such as the building of transport links, can also lead to the destruction of habitat or if destruction is limited, disturbance in the form of increased pollution.

\section{Fire}

Severe fire events and changes in fire regime and water availability are seen to influence a large number of European tree species. This can be the result of both anthropological intervention such as deliberate forest fires or extraction of ground water or natural modification such as drought or flooding. 2017 saw unusually high fire levels across the world, including in the European region (Anon., 2017). The natural fluctuation of water availability and resulting fires can be linked to climate change, with increased drought periods and intensity likely to promote larger fire activity in the European region (Veira et al., 2016; Turco et al., 2017).

\subsection{Population trends}

The population trend (as declining, stable, increasing or unknown) of species is also recorded for all Red List assessments. Overall, the populations of 67 tree species are in decline, including 44 threatened species. 194 species (43\%) in Europe have stable or increasing populations; however for 193 species the population trend is unknown (Figure 6). 


\section{Case study 3 . Islands}

Emily Beech and Malin Rivers,

Botanic Gardens Conservation International

Islands are hotspots of biodiversity and for trees it is no different. GlobalTreeSearch (BGCI, 2017) identifies at least $20 \%$ of tree species as endemic to single island states worldwide. European islands are no exception (Médail et al., 2019); 64 tree species are found on European islands, with 61 (13\%) endemic to European islands.

When talking about European islands for this Red List we include islands associated with Portugal (Azores, Madeira), Spain (Canary Islands, Balearics), France (Corsica), Italy (Sicily, Sardinia), Greece (Crete, Greek Islands), Malta and Cyprus. There are also other small islets, some of them hosting rare or endemic species or subspecies.

European islands cover a range of habitats. The Macaronesian islands are home to Laurisilva forests, ancient forests with a plethora of different tree species and associated other vegetation. Islands such as the Canary Islands are volcanic, with active volcanos contributing rich nutrients in their lava flows, whilst also potentially threatening populations of trees, such as Genista aetnensis (Rivers \& Beech, 2017), which on Sicily is only found around Mt. Etna.
The threats to island tree species are similar across islands, with fire a serious threat to many of their trees. For example, forest fires have increased with intensity and frequency on the island of Madeira, with significant fires in 2010 (Fontinha et al., 2014) and 2016 (Navarro et al., 2017), posing a threat to their native tree species as regeneration often struggles to adapt to new fire regimes.

Invasive species also pose a serious problem to island forests. Invasions from outside the island often have adapted in ways that the native plants cannot compete with. As island plants evolve in isolation from external influences they are adapted only to the natural conditions. When human disturbances and introductions take place, the consequences are often severe with native trees being shaded out by fast growing exotic weeds.

The beauty of the European islands has also contributed to the decline in many island tree species, as these islands become the centres of booming tourist industries. The creation of resorts along the coasts as well as the necessary infrastructure further inland are contributing to land-use change and the destruction of tree habitats.

Care is needed to protect unique island tree flora and the plethora of associated animal and plant life from extinction. Conservation planning must take into account the threat status of these trees and ensure they are protected for years to come.

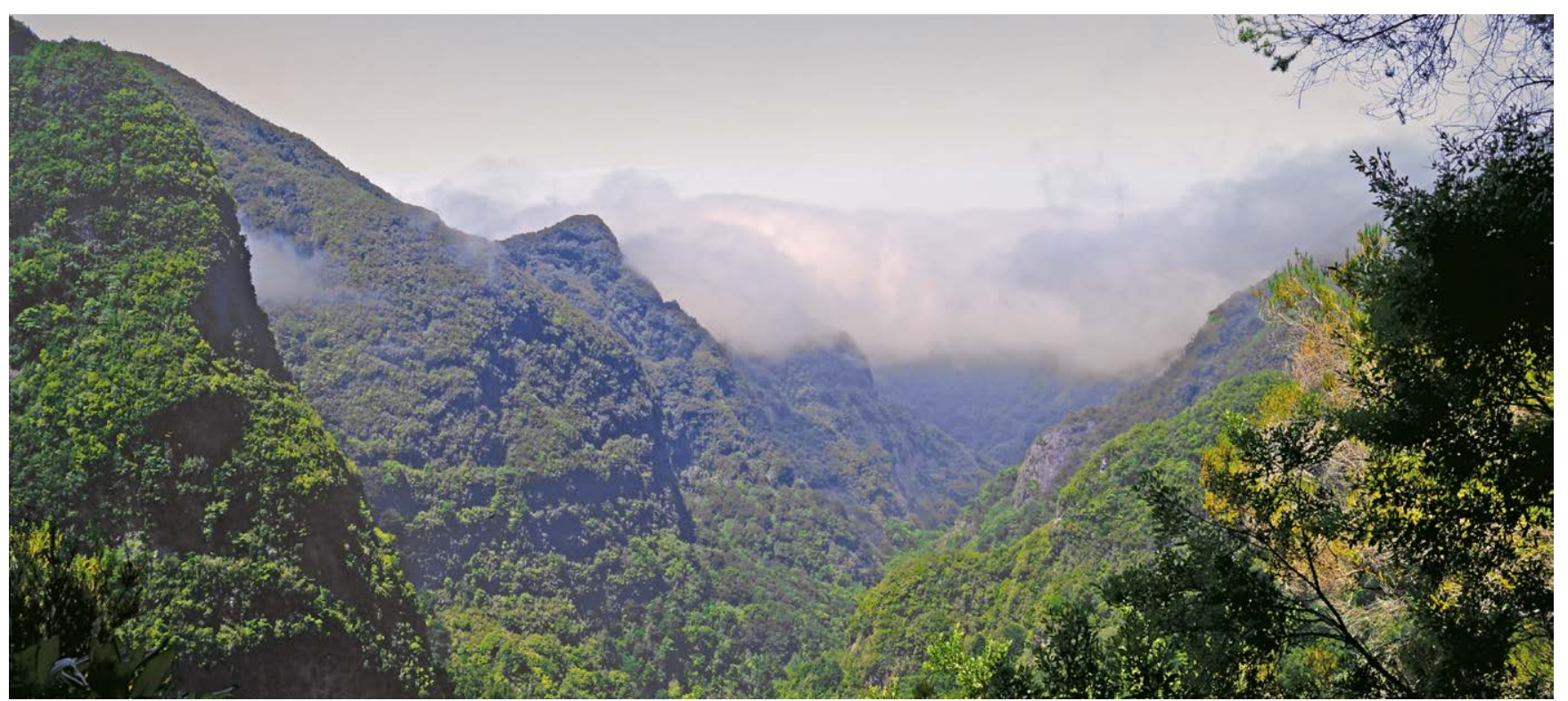

Laurissilva is a forest type that was once widespread in the European region across the Mediterranean, but is now restricted to the European Macaronesian islands, where it too underwent declines as a result of a range of threats including invasive species, forestry and clearance for agriculture. (C) Elena Osipova / IUCNa 


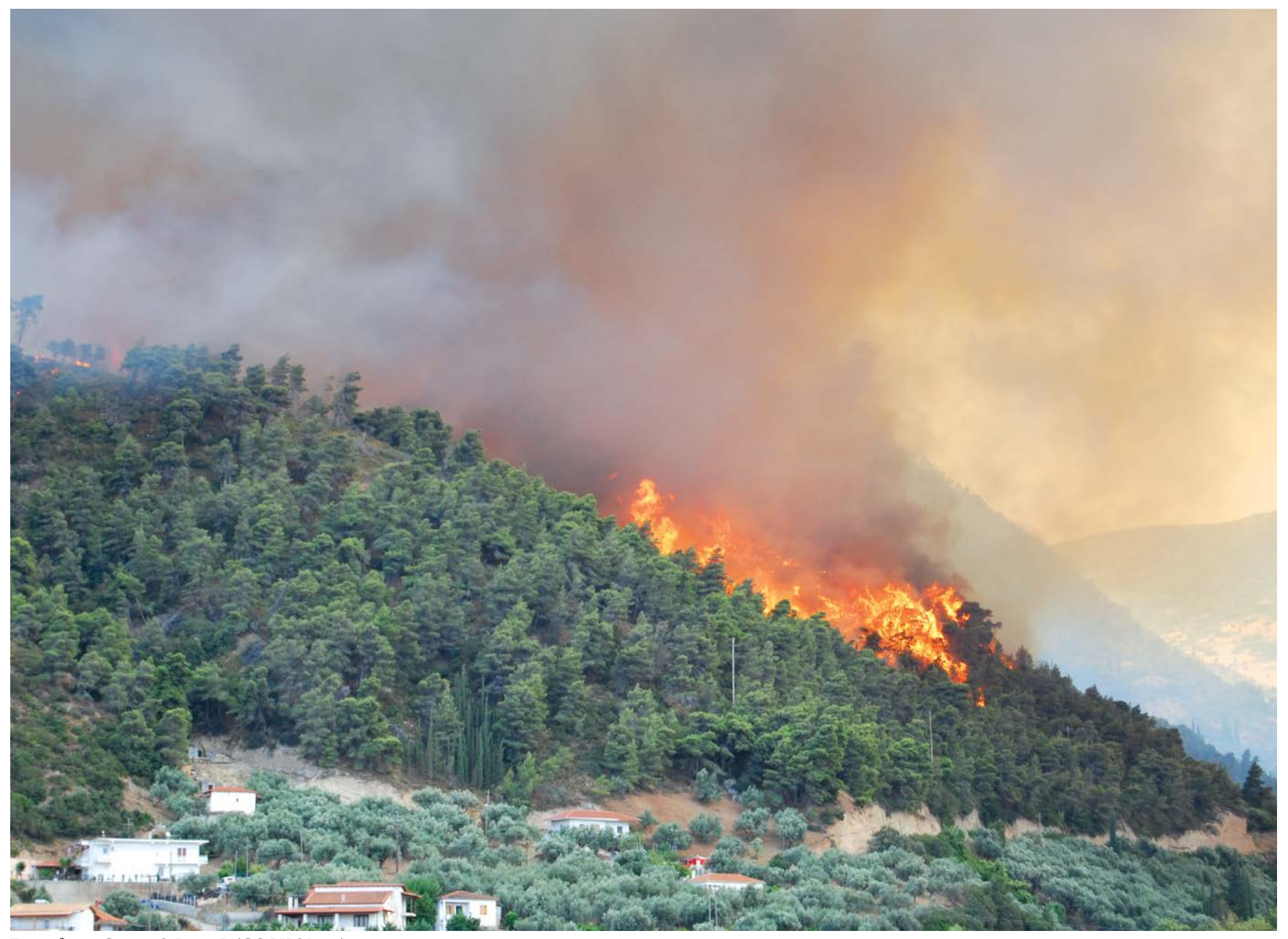

Forest fire in Greece. (C) Lotus R (CC BY-SA 2.0)

Figure 5. The major threats identified to the European tree species.

Invasive and problematic species Land abandonment and other ecosystem modifications Deforestation and wood harvesting Livestock farming Climate change Urban development

Fire Geological events Transportation corridors Human intrusions and disturbance Other threat Agriculture Mining and quarrying Pollution Tree plantations Water use and management Plant collection Threat unknown

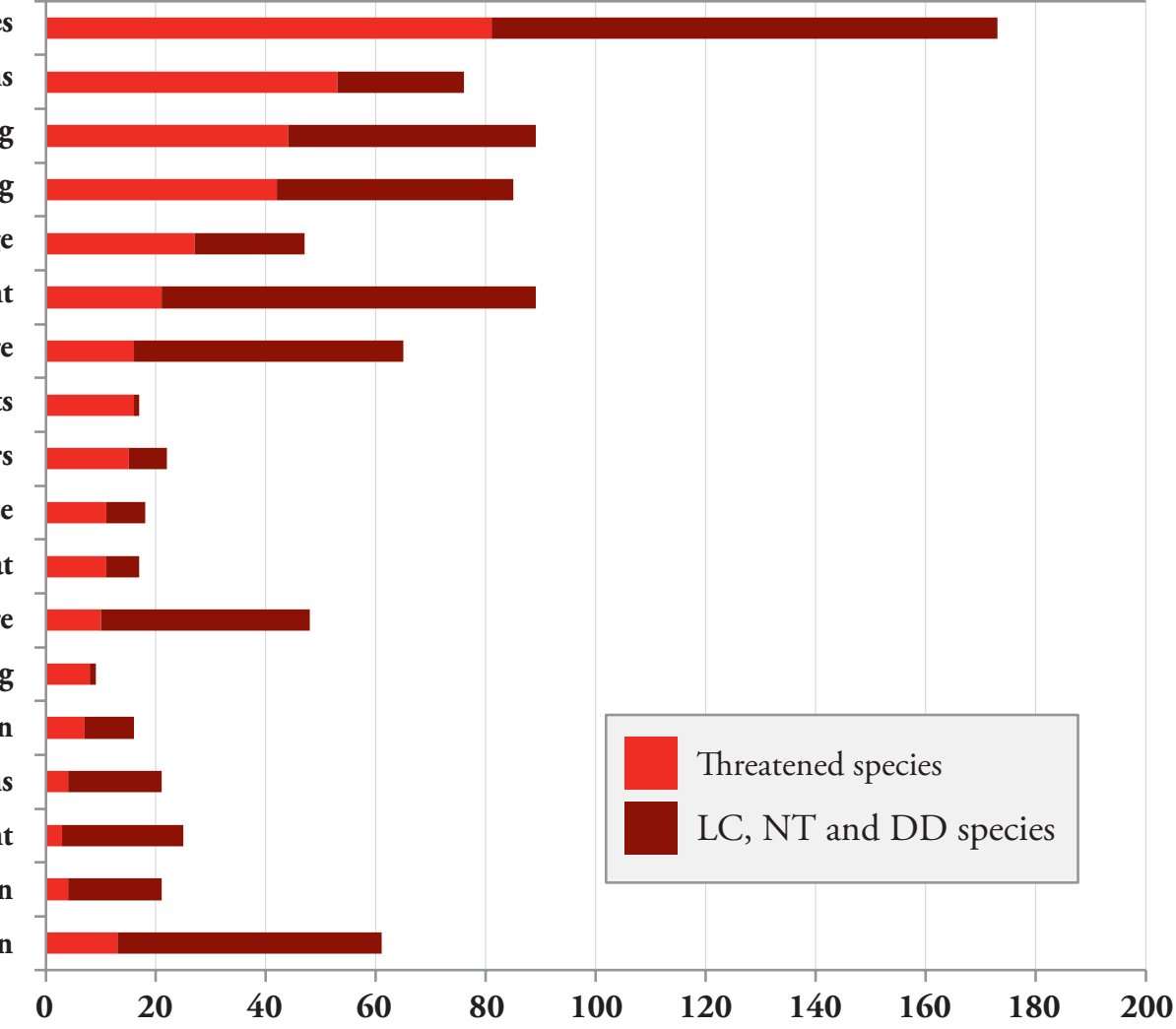


Figure 6. Population trends of European tree species.

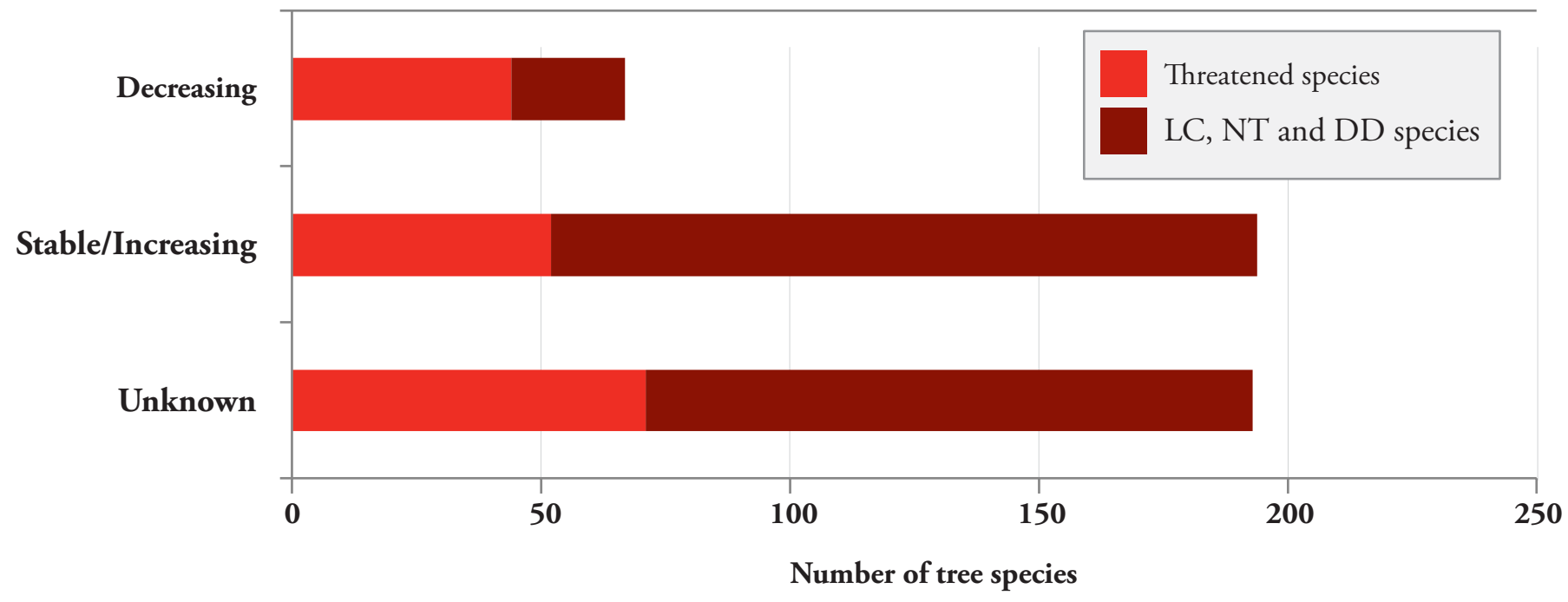

\subsection{Uses}

The majority of European trees ( 245 tree species) have at least one recorded use (Figure 7). 209 tree species have no recorded use, and of these 106 are considered to not be utilised - for the remainder there is no information available.
The uses are very diverse (Figure 7), ranging from food, medicines, construction, fuel, handicrafts etc. Some of these uses may, if overexploited and not monitored, have had a direct effect on the conservation status of the species. The largest single use is horticulture; indeed the ornamental value of European trees is high with $30 \%$ of species used in the horticultural trade. For information on how this is important use is reflected in botanic garden collections see Chapter 4.

Figure 7. The number of European tree species with a recorded use.

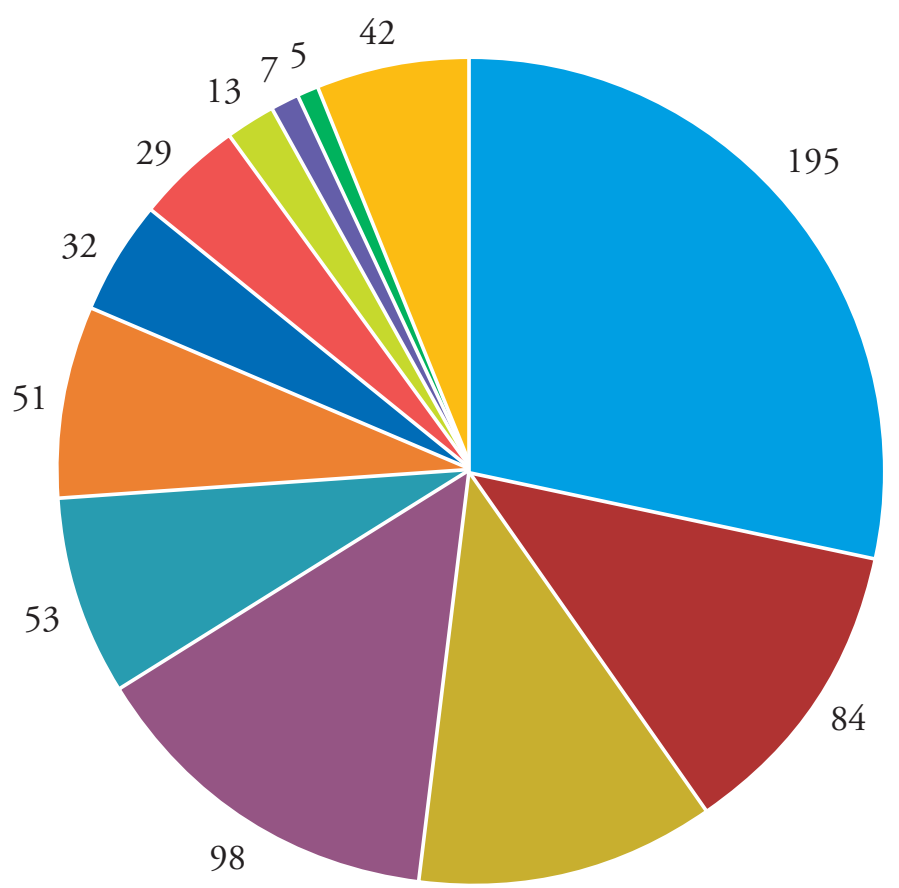

79

Horticulture
Structural materials
Medicine
Food - human \& animal
Fuel
Household goods
Handicrafts, jewellery
Chemicals
Fibre
Research
Wearing apparel, accessories
Other




\section{In situ and ex situ conservation of European trees}

Out of all European trees species, 359 (79\%) are currently found in at least one protected area. However, more studies are needed to establish the scope and effectiveness of these protected areas for tree species. This was unfortunately outside the remit of this project.

For assessing which European trees are conserved $e x$ situ in botanic gardens, arboreta and seed banks around the world, we conducted an ex situ conservation survey. Tree species were matched to records held in the BGCI database PlantSearch (Box 3) (as of 11/07/2017). All collections of European tree species were included, regardless of their geographic origin. It is possible that some of the non-endemic tree collections are of nonEuropean origin.

The ex situ conservation survey identified 19,257 records of European trees found in 643 different institutions. This number represents the presence of a single taxon in a collection within an institution and does not take into account the number of accessions or individuals. Only species records were included in the analysis, records of cultivars or infraspecific taxa were excluded.

\subsection{Species in ex situ collections}

In total, 393 European tree species (87\%) are found in ex situ collections with 61 species (13\%) not found in collections (Figure 8). Of the species not found in ex situ collections, most are assessed as Critically Endangered or Data Deficient (Figure 8).

Of the 168 threatened tree species, 136 species are found in ex situ collections in botanic gardens, arboreta or seed banks. Species that are not found in ex situ collections are not safeguarded against extinction if wild populations are lost. Thirty-two threatened species are currently not found in any ex situ collections, all except Rhamnus lojaconoi are species of Sorbus (Table 4). Further efforts should be made to ensure the remaining threatened species are brought into collections.

\subsection{Number of ex situ collections}

Although a single ex situ collection in a botanic garden or seed bank prevents the extinction of a species, multiple collections are needed for protection from stochastic events or loss from natural causes, and to contain sufficient genetic diversity to enable the collections to be used in restoration or reintroduction programmes. $24 \%$ of threatened European tree species are found in a single collection, and 53\% are found in five or fewer collections. Therefore despite a large proportion of European trees being found in ex situ collections, more can still be done in terms of diversifying these collections, and ensuring they are safe.

Figure 8. The number of tree species found (blue) and not found (light blue) in ex situ conservation collections, including the conservation category of those not found in ex situ collections.

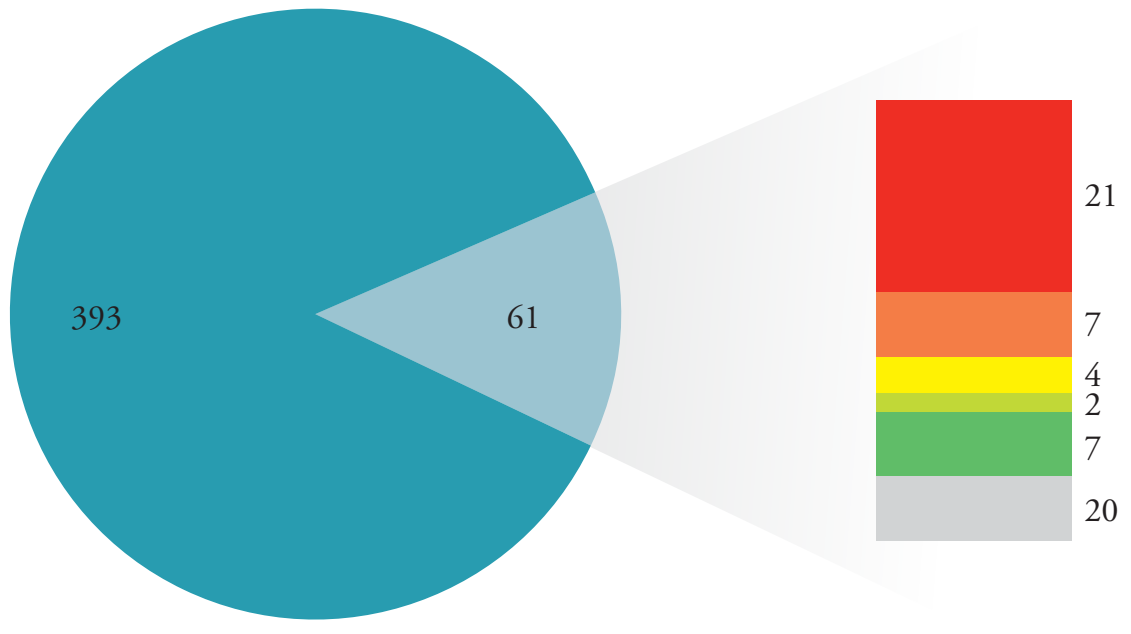

Present 


\section{Species profile: Sorbus albensis}

Martin Lepší

South Bohemian Museum, České Budějovice, Czechia

Sorbus albensis is a tree up to $13 \mathrm{~m}$ high, endemic to the northern Bohemia region of the Czech Republic.

Sorbus albensis bears a unique morphology within this group. With its irregularly serrated to shallowly lobed leaves it is morphologically close to $S$. danubialis (S. aria group). The presence of the other parent, $S$. torminalis is evident in the orange-red colour of the fruits. Both of its supposed parents, i.e. S. danubialis and S. torminalis, and another endemic Sorbus bohemica occur commonly at its localities.

Sorbus albensis is assessed as Endangered. It was recorded at 15 localities in the České Středohoří Mountains, with a restricted range of $20 \mathrm{~km}^{2}$ and its population consists of just 600 individuals.

Sorbus albensis occurs in open habitat such as wood margins, grasslands, shrublands, screes and rocks, and open forests on both acidic and base-rich soils. A majority of individuals occur in human-affected seminatural forests or man-made grasslands or shrublands. Only twice has it been found in relic habitats such as rocks and screes.

This species is threatened by changes in forest management, encouraging the growth of 'high' forests which reduce the reproductive success of Sorbus albensis. In the undergrowth of high forests, it is very often sterile and only produces fruits when there are gaps in the canopy or it reaches the tree layer. Seedling growth is limited by grazing by deer and mouflon at some localities. Rarely, it is able to spread in grasslands on calcareous marls. In good conditions it produces plenty of fruit and seedlings and forms monospecific closed stands.

The population of the species may have been reduced considerably by intensive farming in the past. Conversely, management have maintained open habitats at some localities, allowing the species to establish and survive until now. The species' habitat range is restricted, which is caused by the cessation of grazing within the area, leading to natural succession, causing colonisation of open sites by trees and closing tree canopy in former open forests. Succession is a continuing threat to the species, as is also the case for many other European Sorbus species.
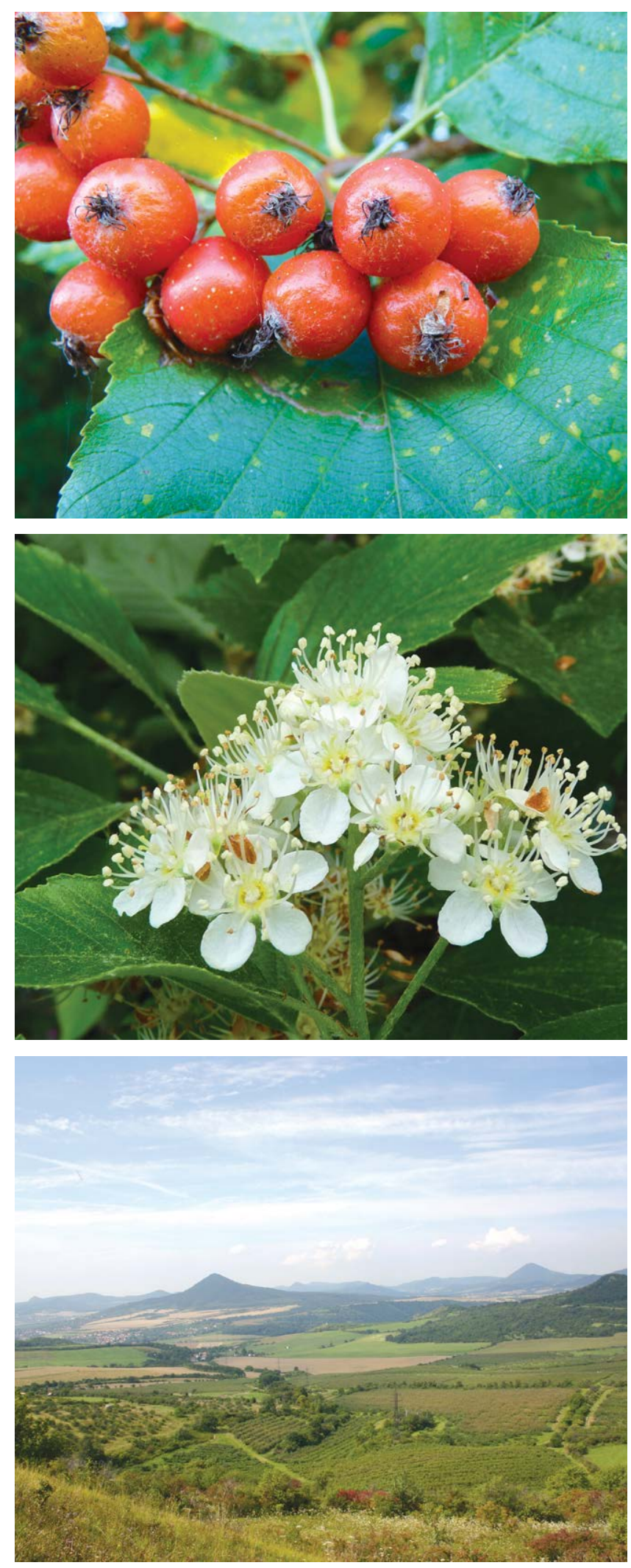

(C) Martin Lepší 
Table 4. Threatened European tree species not found in $e x$ situ collections.

\begin{tabular}{ll}
\hline Rhamnus lojaconoi & Sorbus moravica \\
Sorbus acutiserrata & Sorbus polgariana \\
Sorbus amici-petri & Sorbus pontis-satanae \\
Sorbus barabitsii & Sorbus pyricarpa \\
Sorbus bodajkensis & Sorbus scannelliana \\
Sorbus bosniaca & Sorbus scepusiensis \\
Sorbus busambarensis & Sorbus seyboldiana \\
Sorbus dracofolia & Sorbus slovenica \\
Sorbus gerecseensis & Sorbus subdanubialis \\
Sorbus harziana & Sorbus thayensis \\
Sorbus keszthelyensis & Sorbus tobani \\
Sorbus klasterskyana & Sorbus udvardyana \\
Sorbus kmetiana & Sorbus ujhelyii \\
Sorbus lonetalensis & Sorbus vallerubusensis \\
Sorbus magocsyana & Sorbus veszpremensis \\
Sorbus meyeri & Sorbus zertovae \\
\hline
\end{tabular}

\section{Box 3. PlantSearch}

BGCI's PlantSearch database is a global database of plants in cultivation. It is available online, and it is free to contribute to and access. PlantSearch connects around 2,000 researchers and horticulturists to collections every year. Locations

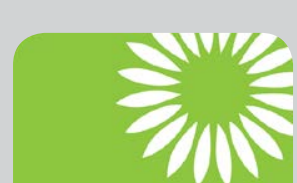

PLANT SEARCH and gardens are not publicly revealed and requests can be made via blind email messages. PlantSearch is an easy way for ex situ collection holders to contribute to broader ex situ assessments, such as this survey.

https://tools.bgci.org/plant_search.php

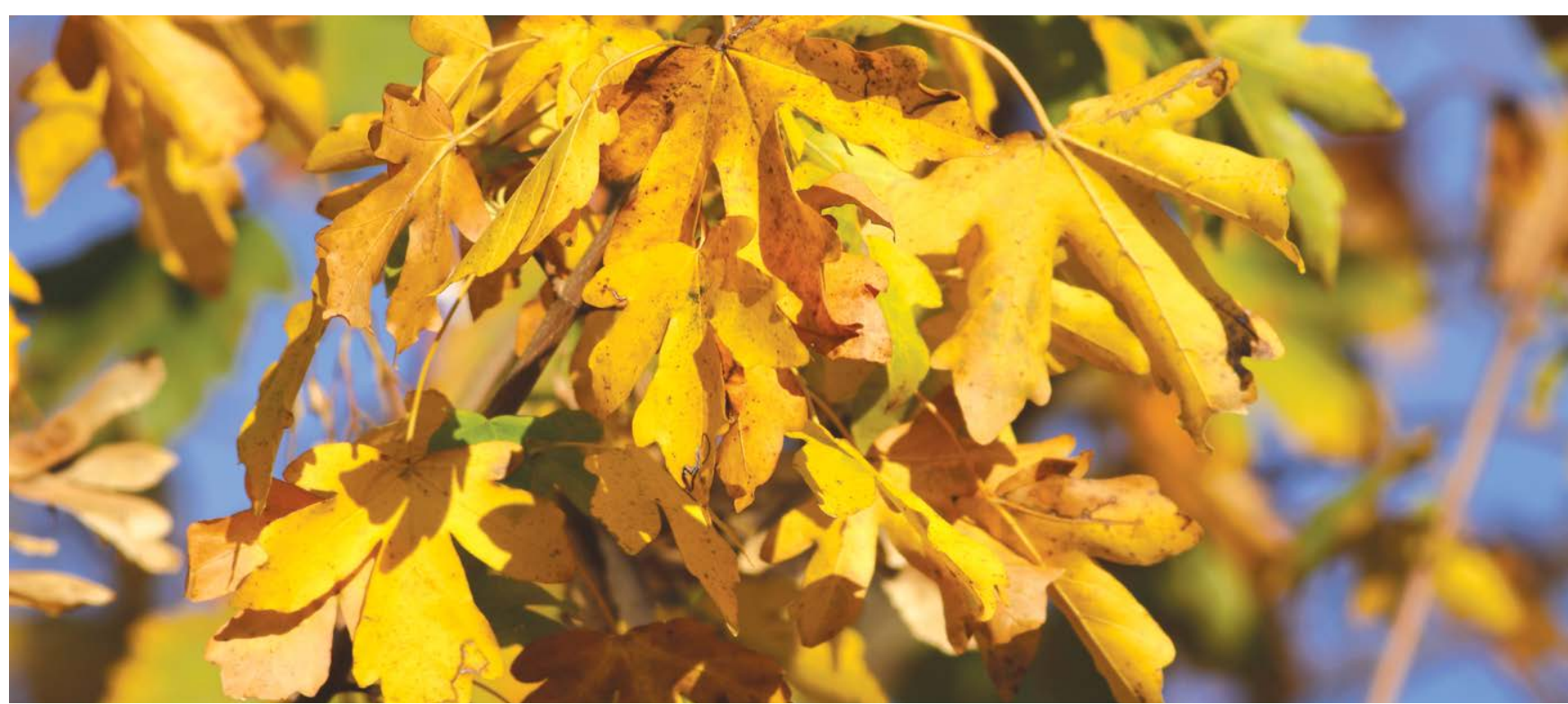

Acer campestre (LC) is widespread across the European region. As well as being a common ornamental tree and frequent in botanical gardens, the wood is widely used. (C) Dean Morley (CC BY-ND 2.0)

In contrast, some species are found in a very large high ornamental value. The top ten species in the largest number of ex situ collections, these are often linked with number of collections are shown in Table 5 .

Table 5. The top-10 European tree species found in the largest number of ex situ collections.

\begin{tabular}{llcc}
\hline Taxon & English common name & Rating & Number of collections \\
\hline Cornus mas & Cornelian Cherry & LC & 233 \\
Picea abies & Norway Spruce & LC & 228 \\
Buxus sempervirens & Box & LC & 225 \\
Quercus robur & European Oak & LC & 223 \\
Taxus baccata & Common or European Yew & LC & 212 \\
Laurus nobilis & Bay Laurel & LC & 210 \\
Acer campestre & Field Maple & LC & 208 \\
Fagus sylvatica & European Beech & LC & 208 \\
Pinus sylvestris & Scots Pine & LC & 208 \\
Picea omorika & Serbian Spruce & EN & 203 \\
\hline
\end{tabular}




\section{Species profile: Serbian Spruce - Picea omorika}

Martin Gardner,

IUCN SSC Conifer Specialist Group \& International Conifer Conservation Programme

Serbian Spruce (Picea omorika) is a very distinctive European endemic conifer with its narrow pencil-like shape and distinctive flattened needles which have two broad silvery-white bands beneath. Soon after its discovery in 1875 by the Serbian botanist Josif Pančić, it was introduced to cultivation in 1889 , since when it has been widely cultivated for commercial forestry and as an ornamental tree.

It has a relatively restricted natural distribution adjacent to the Drina River of Bosnia and Herzegovina and Serbia where it has an altitudinal range of 800-1,500 meters above sea-level. Within its four main locations it occurs in 25 sites with nearly half of these occurring in Serbia's Tara National Park. In Bosnia and Herzegovina, it is confined to the eastern part of the country in Republika Srpska with the largest cluster of sites between Višegrade and Srebrenica and is contiguous with the main location in Serbia.

Typically it grows on steep north to northwest-facing slopes which overlay igneous rocks. In Serbia there is one unusual site on peatland and another on serpentine soils that are derived from ultramafic rocks. It occurs with other coniferous species such as Abies alba, Picea abies, Pinus nigra and Pinus sylvestris. Until the middle of the 19th century the natural range of Serbian Spruce was less fragmented than it is today, which has mainly been caused by forest clearing and wildfires. Serbian Spruce is dependent on catastrophic events for good recruitment and healthy subsequent growth to take place. Dieback related to drought has been observed in recent years, which is thought to be a response to extreme weather events suggesting that this species is likely to face difficulties in adapting to climate change within its natural range.

Serbian Spruce, considered Endangered, is afforded protection throughout its natural range. Researchers recommend the removal of competitive trees such as Fagus sylvatica and planting in areas of its natural range which are not currently occupied by this species. The 2014 BGCI survey of ex situ conifer collections reports that the Serbian Spruce is grown in 209 sites but only 42 of these contain plants from known wild origin. The International Conifer Conservation Programme (ICCP) based at Royal Botanic Garden Edinburgh and in collaboration with Bedgebury National Pinetum, has made two visits to sample seed from across its natural range. The ICCP has planted 722 plants in 65 sites. Seed from the native forests were also deposited in the Millennium Seed Bank, at Wakehurst.

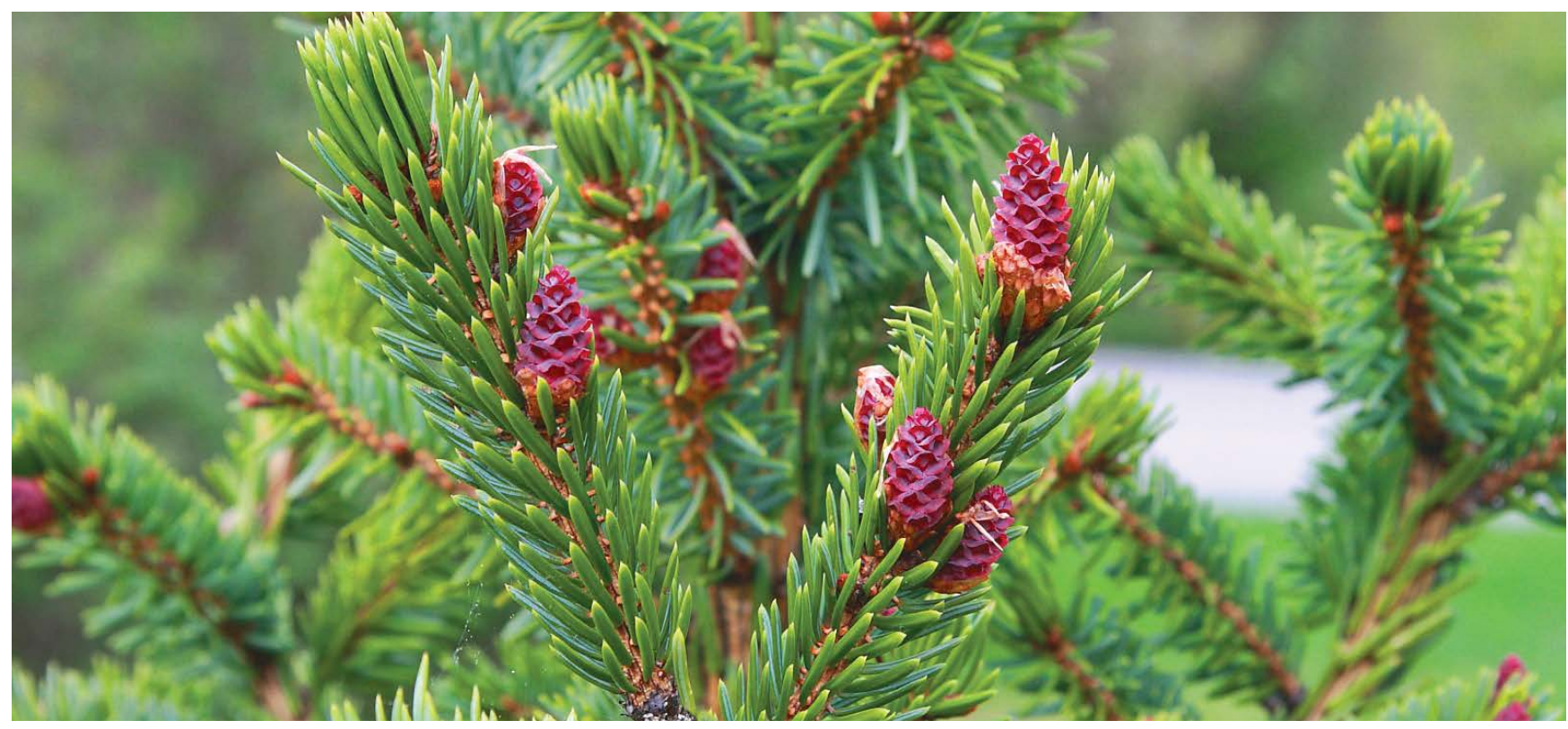

Picea omorika seed cones, shown here in cultivation in Estonia, outside its natural range. (C) Iifar / Wikimedia 


\section{Comparison with other European Red Lists}

In comparison with other groups that have been assessed on a European scale, trees are among the most threatened species in Europe. Other plant groups that have been assessed are: 'policy plants', crop wild relatives, aquatic plants (Bilz et al., 2011), medicinal plants (Allen et al., 2014) and lycopods and ferns (García Criado et al., 2017). There is some overlap of the species included in these reports, but the result still shows that with $42 \%$ threatened species, trees have the highest proportion of threatened species, apart from 'policy plants'. It is not surprising that 'policy plants' contain more threatened species, as the species were selected due to their conservation concern. In comparison beyond plants, only European freshwater molluscs are more threatened than trees (Table 6).

Table 6. Summary of European Red List assessments with the proportion of threatened species (mid-point value).

\begin{tabular}{lcl}
\hline Taxonomic group & Threatened species (\%) & Reference \\
\hline Freshwater molluscs & $59 \%$ & Cuttelod et al., 2011 \\
'Policy' plants* & $57 \%$ & Bilz et al., 2011 \\
Trees & $42 \%$ & This report \\
Freshwater fishes & $40 \%$ & Freyhof \& Brooks, 2011 \\
Grasshoppers, crickets and bush-crickets & $29 \%$ & Hochkirch et al., 2016 \\
Amphibians & $23 \%$ & Temple \& Cox, 2009 \\
Terrestrial molluscs & $22 \%$ & Cuttelod et al., 2011; Neubert et al., 2019 \\
Mosses, liverworts and hornworts & $22 \%$ & Hodgetts et al., 2019 \\
Reptiles & $20 \%$ & Cox \& Temple, 2009 \\
Lycopods and ferns & $20 \%$ & García Criado et al., 2017 \\
Dragonflies & $16 \%$ & Kalkman et al., 2010 \\
Crop wild relatives* & $16 \%$ & Bilz et al., 2011 \\
Saproxylic beetles* & $15 \%$ & Nieto \& Alexander, 2010 \\
Mammals & $15 \%$ & Temple \& Terry, 2007 \\
Birds & $13 \%$ & BirdLife International, 2015 \\
Bees & $9 \%$ & Nieto et al., 2014 \\
Butterflies & $9 \%$ & van Swaay et al., 2010 \\
Aquatic plants* & $8 \%$ & Bilz et al., 2011 \\
Marine fishes & $8 \%$ & Nieto et al., 2015 \\
Medicinal plants & $2 \%$ & Allen et al., 2014 \\
\hline
\end{tabular}

* European Red Lists assessing a selection, rather than complete set, of species. 


\section{Policy and conservation framework of European trees}

Plant conservation in Europe is covered to varying degrees by a series of international, European, European Union and national strategies and legal frameworks relating both specifically to plant conservation and to plant conservation within the broader biodiversity framework.

\subsection{Global policy context}

All European countries (as well as the EU itself) are Parties to the UN Convention on Biological Diversity (CBD). The CBD Strategic Plan 2011-2020 includes 20 targets (Aichi Targets) that guide the implementation of the $\mathrm{CBD}$ and link to other international environmental agreements. Of relevance, Aichi Target 12 focuses on preventing the extinction of known threatened species and improving their status (Convention on Biological Diversity, 2011). The information provided in this Red List of European trees contributes to measuring progress made towards meeting this target, especially because some species have been re-assessed, allowing changes in conservation status over time to be measured.

Within the framework of the CBD, the Global Strategy for Plant Conservation (GSPC) (CBD, 2002) was developed in response to a recognised need for a greater focus on plants within the broader biodiversity agenda. The GSPC was adopted by the Parties to the CBD in 2002 and all signatory governments were committed to delivering the Strategy's 16 ambitious targets by 2010, which were subsequently updated to run until 2020 (CBD, 2012). This project directly addresses Target 2 (calling for assessment of the conservation status of all plant species), but many of the other targets are also relevant for the conservation of trees.

Since its adoption, the GSPC has motivated action to save plant diversity from extinction at national, regional and international levels and in Europe, several countries (e.g. Spain, Ireland and the UK) have used the GSPC as a basis for developing national plant conservation strategies.

There are currently no European trees listed on annexes of the Convention on International Trade in Endangered Species of Wild Fauna and Flora (CITES). For more information on CITES is available from the CITES section on the BGCI website: www.bgci.org/our-work/ policy-and-advocacy/cites/.

\subsection{European policy context}

To coordinate the implementation of the GSPC at the regional level, the European Strategy for Plant Conservation (ESPC) was developed in 2001 by the Planta Europa network and the Council of Europe, in partnership with other related conservation organisations.

European countries and EU Member States are signatories to several conventions aimed at conserving biodiversity, including the Conservation of European Wildlife and Natural Habitats (Bern Convention). The Bern Convention was the first convention developed

\section{Box 4: Important Plant Areas (IPA)}

Plant habitat conservation efforts have in part been focused through the identification of Important Plant Areas (IPAs). IPAs are natural or semi-natural sites exhibiting exceptional botanical richness, or supporting rare, threatened or endemic plant species or vegetation of high botanical value. The European IPA programme, coordinated by PlantLife International and IUCN, has three objectives: to identify within each biogeographic zone the most important sites for the conservation of plants; to promote awareness of the importance and need to conserve these areas; to promote direct conservation action and funding towards these sites. To date, more than 16 European countries have been actively engaged in IPA identification projects and more than 1,770 IPAs have been identified (Plantlife, 2010). Online data on the sites, their qualifying features and threats are available at www.plantlifeipa.org. 


\section{Box 5: Plant Micro-Reserves (PMRs)}

Another form of protection for plants are Plant Micro-Reserves (PMRs), which are present in several European countries. These are based on the use of vegetation fragments as small-scale reserves to conserve and monitor populations of rare, endemic and threatened species (Kadis et al., 2013; Laguna et al., 2016). The concept is built on the basis of a voluntary but non-reversible contribution of land property, both public and private, with the goal of creating a network of micro-areas. PMRs have been the focus of targeted EU LIFE funds in a number of European countries, for example, in Cyprus (LIFE08 NAT/CY/000453), Greece (Crete LIFE04 NAT/GR/000104), and Bulgaria (LIFE08 NAT/BG/000279).

specifically for the conservation of wild European flora and fauna and their natural habitats. It also focuses on promoting European co-operation in this field. It requires Member States of the Council of Europe to ensure conservation of all wild plant and animal species; to increase cooperation between states; and to afford special protection to the most vulnerable species. The Bern Convention is a binding international legal instrument in the field of nature conservation, which covers the whole of the natural heritage of the European continent and extends to some states of Africa. In Appendix I of the Bern Convention (Strictly Protected Flora Species), a total of seven tree species are listed (Zelkova abelicea, Pyrus anatolica, Tetraclinis articulata, Euphorbia margalidiana, Abies nebrodensis, Ribes sardoum, Phoenix theophrasti).

In line with international commitments, the EU itself has committed to a long-term (2050) vision and midterm headline target for biodiversity, which is "To halt the loss of biodiversity and the degradation of ecosystem services in the EU by 2020 and restore them in so far as possible, while stepping up the EU contribution to averting global biodiversity loss." This target underpins the EU Biodiversity Strategy 2011-2020 which aims to halt the loss of biodiversity and ecosystem services. The strategy sets out six targets and 20 actions to achieve these objectives by 2020 .

EU nature legislation, most notably the Birds Directive and the Habitats Directive, form the backbone of biodiversity policy and the legal basis for the nature protection network. At the centre of these Directives is the creation of a coherent ecological network of protected areas throughout Europe - known as Natura 2000. Some 27,000 sites have so far been included in the Natura 2000 network and collectively they cover nearly one fifth of the EU land and marine area (European Commission, 2016). 53 of the 233 Annex 1 habitats are forest habitats. Even though many of the threatened trees were recorded in at least one protected area (including national parks, Natura 2000 sites or nature reserves), the management of protected areas rarely focuses directly on the threatened trees. One example is the Natura 2000 habitat, Macaronesian laurel forests. Conservation management actions include selective cutting to encourage regrowth, converting plantations into laurel forest, removing invasive species and restoring populations of threatened species such as Morella rivas-martinezii (Guimarães \& Olmeda, 2008).

\subsection{Red List versus priority for conservation action}

Assessing the extinction risk and setting conservation priorities are related but distinct processes. The purpose of the IUCN Red List assessment is to produce a relative estimate of the likelihood of extinction of a taxon that can be used, with other data, to identify and prioritise species for conservation action. On the other hand, setting conservation priorities also considers other factors

\section{Box 6: Species Action Plans}

In addition, several countries have developed management or action plans for several species, and have legislation in place to protect certain species legally. Some examples of successful action plans include UK Biodiversity Action Plans such as for Juniperus communis (JNCC, 2010) and the Zelkova Global Action Plan (Kozlowski \& Gratzfeld, 2013). 


\section{Box 7: High Conservation Value}

The High Conservation Value (HCV) approach was first developed by the Forest Stewardship Council (FSC), but recently it has proven useful for identifying and managing environmental and social values in other production landscapes (Brown et al., 2013). HCV is now widely used in certification standards (forestry, agriculture and aquatic systems) and more generally for resource use and conservation planning. The HCV system recognizes and includes all above mentioned global and European policies and practice. The FSC developed the HCV concept as part of its standard (Principle 9) to ensure maintenance of significant or critical environmental and social values in the context of forest certification. This is a very effective way for the forestry sector to ensure that the appropriate management for tree species conservation is in place in many EU and non-EU countries (Ioras et al., 2009; Maesano et al., 2016).

such as ecological, phylogenetical, historical, economical, or cultural preferences for some taxa over others. Also, the probability of success of conservation actions, availability of funds or personnel, cost-effectiveness and legal frameworks for the conservation of threatened taxa is considered. In the context of regional risk assessments, several additional pieces of information are valuable for setting conservation priorities. For example, it is important to consider not only conditions within the region, but also the status of the taxon from a global perspective and the proportion of the global population that occurs within the region. The decision on how these three variables, and the other factors, are used for establishing conservation priorities is a matter for the regional authorities to determine, considering the assessment status of the species of concerned.

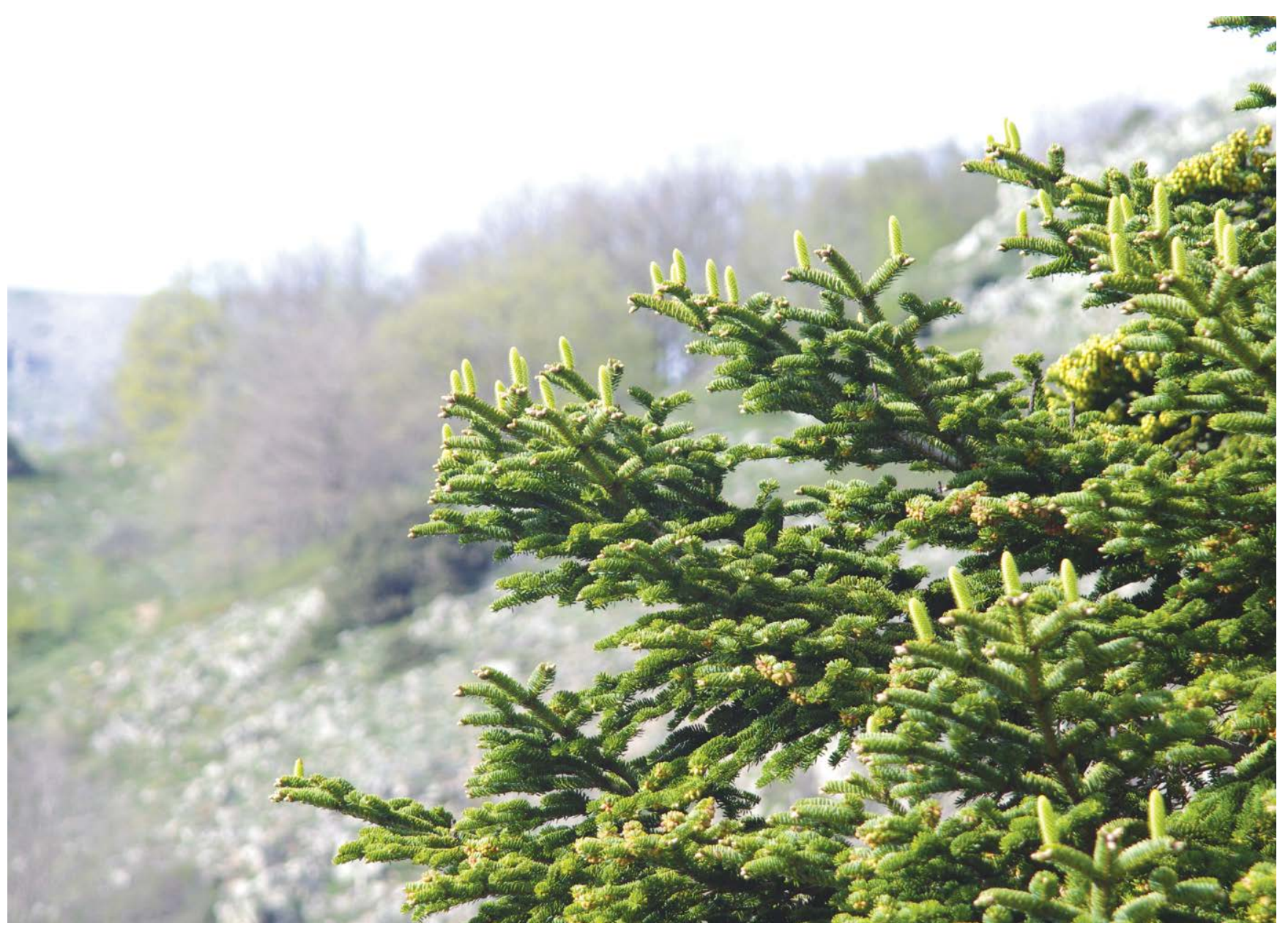

The Sicilian Fir Abies nebrodensis does not grow in the Nebrodi Mountains, it is actually found in the Madonie Mountains in the north-central part of Sicily. It is Critically Endangered as a result of past decline, and because of the current small population size, with just 25 fertile trees out of the 32 known adult trees. It was considered to be extinct at once point, but a small population was discovered in 1957, and has benefited from a number of LIFE-funded conservation initiatives. (C) Angelo Troì/IUCN SSC Mediterranean Plant Specialist Group. 


\section{Recommendations}

\section{Action on the ground}

- Assess the impact of changes in habitat management for all species of tree to determine whether these processes are beneficial to certain species.

- Implement effective protected area management.

- Ensure that that all tree species are adequately represented in protected areas.

\section{Ex situ conservation}

- Expand ex situ collections to incorporate threatened species not found in ex situ collections as a priority.

- Diversify collections of threatened species to incorporate increased genetic diversity to make material available for restoration purposes.

- Increase the collections of species in their country of origin.

\section{Research and monitoring}

- The arrival and spread of invasive species, pests and diseases within Europe and globally continues to be poorly controlled (Seebens et al., 2017). Monitoring and evaluation are needed to identify risks to European trees.

- Undertake further research into the impacts of climate change on both forest landscapes and individual species, including the scope for range migration and connectivity (Meier et al., 2011).

- Undertake necessary research to determine the conservation status of the Data Deficient tree species of Europe.

- Promote transboundary collaborations and a robust network of experts.

\section{Policy recommendations}

- Update the European Red List at least every decade to ensure that information about taxa and their threat status is kept up to date, and to allow trends to be elucidated.

- Repeated assessments would allow for the development of a Red List Index for European tree species (EEA, 2010).

- Implement strategies at national levels to mobilise necessary actions to protect threatened tree species and their habitats.

\section{Increased awareness}

- Promote the findings and recommendations of the European Red List of Trees to diverse audiences and stakeholders within countries to increase knowledge of the threats faced by European trees. 


\section{Conclusion}

The European Red List of Trees represents the first comprehensive assessment of the threat status of the regions' tree species. Of the 454 tree species considered native to the European region, 168 of the species are threatened (i.e. assessed as Vulnerable, Endangered or Critically Endangered, and therefore having an elevated risk of extinction). No tree species are yet extinct, however, 57 species (13\%) were found to be Data Deficient. As a consequence, the proportion of threatened species could be between 37\% (if no DD species are considered threatened) and nearly 50\% (if all DD species are considered threatened) for Europe.
The mid-point value (42\%) provides the best estimation of the proportion of threatened tree species, placing European trees as the third most-threatened group of species yet assessed for the European Red List, after freshwater molluscs and the 'policy plants' (plant taxa listed in European and international policy instruments, a group selected for their conservation concern).

To address this very high level of threatened species, it is essential that the recommendations made above are implemented across the European region.

These assessments complement existing regional or national conservation assessments to allow targeted conservation planning. These assessments should be used to direct policy in order to ensure that the species considered threatened are protected both in and ex situ.

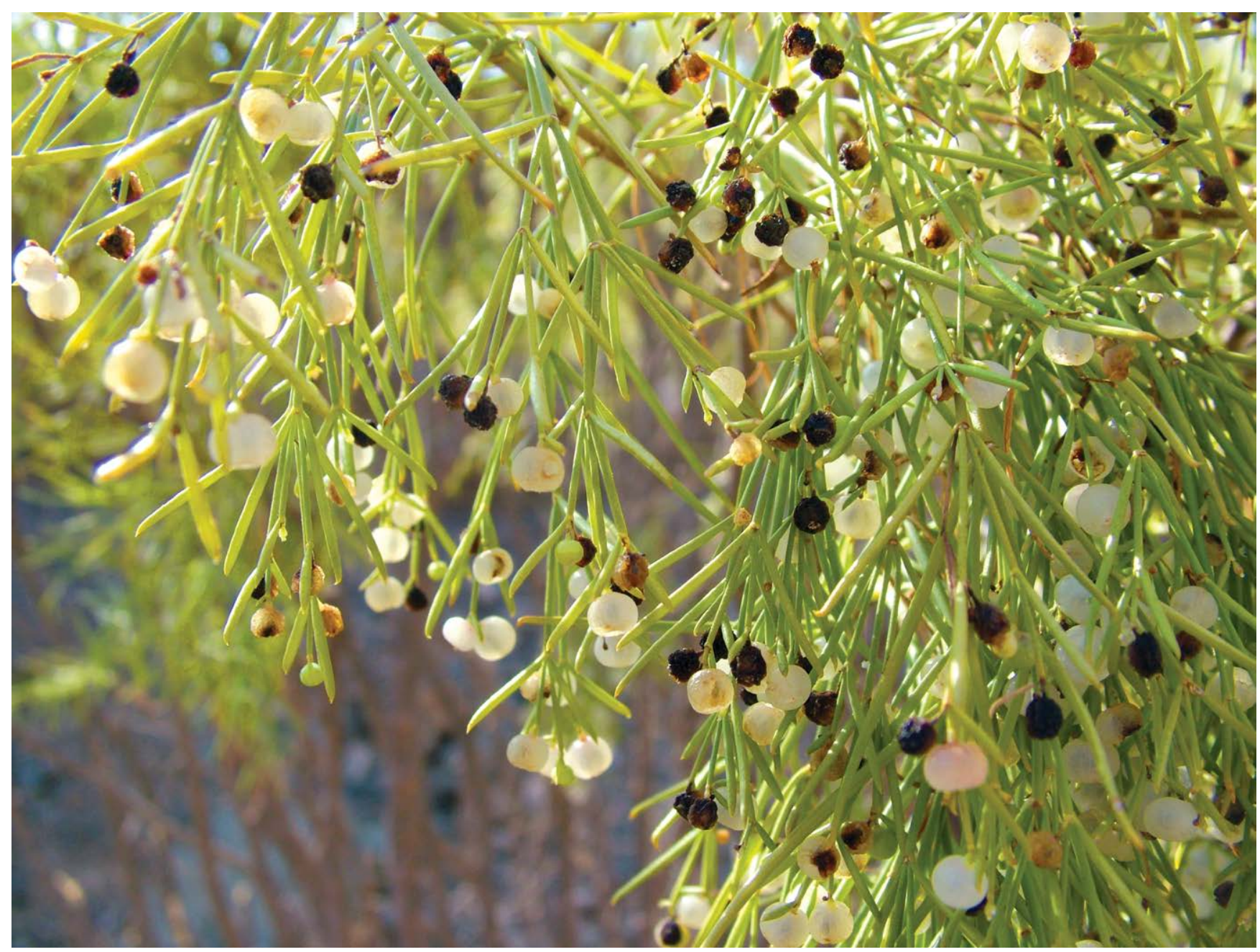

Balo (Plocama pendula), shown here with its fruits, is a small tree that is endemic to the Canary Islands. Widespread across most of the islands, it is Least Concern. It was used in the past to produce a dye, as fodder and as bedding for livestock, and for fuelwood, and to make tools. (C) Stephan Scholz 


\section{References}

Allen, D.J., Bilz, M., Leaman, D.J., Miller, R.M., Timoshyna, A. and Window, J. (2014). European Red List of Medicinal Plants. Luxembourg: Publications Office of the European Union. https://doi.org/10.2779/907382

Allen, D.J. and Khela, S. (2017). 'Aesculus hippocastanum (errata version published in 2018)'. The IUCN Red List of Threatened Species 2017: e.T202914A122961065.

Andrušaitis, G. (ed.) (2003). Red Data Book of Latvia, Vol. 3. Vascular Plants. Riga: Institute of Biology, Latvia University.

Anon. (2012). Crvena Lista Zaštićenih Vrsta Flore i Faune Republike Srpske. World Bank-Ministry of Physical Planning, Construction and Ecology of Republika Srpska.

Anon. (2017). Editorial: 'Spreading like wildfire'. Nature Climate Change 7 (755). https://doi.org/10.1038/ nclimate3432

Anthos (2016). Sistema de Información Sobre Las Plantas de España. http://www.anthos.es

ArtDatabanken (2015). Rödlistade Arter i Sverige 2015. Uppsala, Sweden: ArtDatabanken SLU.

Bachman, S., Moat, J., Hill, A.W., de Torre, J. and Scott, B. (2011). 'Supporting Red List Threat Assessments with GeoCAT: Geospatial Conservation Assessment Tool'. ZooKeys 150: 117-26. https://doi.org/10.3897/ zookeys.150.2109

Bañares, Á., Blanca, G., Güemes, J., Moreno, J.C. and Ortiz, S. (eds.) (2010). Atlas y Libro Rojo de La Flora Vascular Amenazada de España. Adenda 2010. Madrid: Dirección General de Medio Natural y Política Forestal (Ministerio de Medio Ambiente, y Medio Rural y Marino) - Sociedad Española de Biología de la Conservación de Plantas.

Barredo, J.I., Caudillo, G.C. and Mauri, A. (2017). Mediterranean habitat loss under RCP4.5 and RCP8.5 climate change projections - Assessing impacts on the Natura 2000 protected area network. Luxembourg: Publications Office of the European Union. https://doi.org/10.2760/622174

Botanic Gardens Conservation International (BGCI) (2017). GlobalTreeSearch. London: Botanic Garden Conservation International.www.bgci.org/global_tree_search

Bilz, M., Kell, S.P., Maxted, N. and Lansdown R.V. (2011). European Red List of Vascular Plants. Luxembourg: Publications Office of the European Union. https://doi. org/10.2779/8515

BirdLife International (2015). European Red List of Birds. Luxembourg: Publications Office of the European Union. https://doi.org/10.2779/975810
Broggi, M.F., Waldburger, E. and Staub, R. (2006). Rote Liste Der Gefährdeten UndSeltenen Gefässpflanzen Des Fürstentums Lichtenstein. Vaduz: Amtlicher Lehrmittelverlag.

Brown, E., Dudley, N., Lindhe, A., Muhtaman, D., Stewart, C. and Synnott, T. (2013). Common Guidance for the Identification of High Conservation Values. Oxford: HCV Resource Network.

Brundu, G. and Richardson, D.M. (2015). Code of conduct on plantation forestry and invasive alien trees. First draft-TPVS/Inf. Council of Europe, Strasbourg.

BSBI (2017). BSBI Distribution Database. Durham: Botanical Society of Britain and Ireland (BSBI). https://database. bsbi.org/

Camia, A., Robert, N., Jonsson, R., Pilli, R., García-Condado, S., López-Lozano, R., van der Velde, M., Ronzon T., Gurría P., M’Barek, R., Tamosiunas, S., Fiore, G., Araujo, R., Hoepffner, N., Marelli, L. and Giuntoli, J. (2018). Biomass Production, Supply, Uses and Flows in the European Union: First Results from an Integrated Assessment. Scientific and Technical Research Reports. Luxembourg: Publications Office of the European Union. https://doi. org/10.2760/181536

Caudullo, G. and de Rigo, D. (2016). 'Ulmus - elms in Europe: distribution, habitat, usage and threats'. In: San-MiguelAyanz, J., de Rigo, D., Caudullo, G., Houston Durrant, T., Mauri, A. (eds.), European Atlas of Forest Tree Species. Luxembourg: Publication Office of the European Union. https://doi.org/10.2788/4251

Caudullo, G., Welk, E. and San-Miguel-Ayanz, J. (2017). 'Chorological maps for the main European woody species'. Data in Brief 12: 662-666. https://doi.org/10.1016/j. dib.2017.05.007

Cheffings, C.M. and Farrell, L. (eds.) (2005). The Vascular Plant Red Data List for Great Britain. Species Status No. 7. Peterborough: Joint Nature Conservation Committee.

Colling, G. (2005). Red List of the Vascular Plants of Luxembourg. Paris: Musée national d'histoire naturelle. http://floredunordest.free.fr/IMG/pdf/ListeRougeLux.pdf

CBD (2002). Global Strategy for Plant Conservation. Convention on Biological Diversity (CBD). Richmond, UK: Botanic Gardens Conservation International.

_ (2011). Aichi Biodiversity Targets. Montreal: Secretariat of the Convention on Biological Diversity (CBD). https:// www.cbd.int/sp/targets

_ (2012). Global Strategy for Plant Conservation: 2011-2020. Published by Botanic Gardens Conservation International 
for the Convention on Biological Diversity. Richmond, UK: Botanic Gardens Conservation International.

Cox, N.A. and Temple, H.J. (2009). European Red List of Reptiles. Luxembourg: Office for Official Publications of the European Communities. https://doi.org/10.2779/74504

Cuttelod, A., Seddon, M. and Neubert, E. (2011). European Red List of Non-Marine Molluscs. Luxembourg: Publications Office of the European Union. https://doi. org/10.2779/84538

Didukh, Y.P. (2009). Red Data Book of Ukraine. Plant Kingdom. Kyyiv, Globalkonsalting.

Dihoru, Y.P. and Negrean, G. (2009). Red Book of Vascular Plants of Romania. Editura Academiei Române. Bucureşti.

Doblas-Miranda, E., Alonso, R., Arnan, X., Bermejo, V., Brotons, L., de las Heras, J., Estiarte, M., Hódar, J.A., Llorens, P., Lloret, F., López-Serrano, F.R., MartínezVilalta, J., Moya, D., Peñuelas, J., Pino, J., Rodrigo, A., Roura-Pascual, N., Valladares, F., Vilà, M., Zamora, R. and Retana, J. (2017). 'A review of the combination among global change factors in forests, shrublands and pastures of the Mediterranean Region: Beyond drought effects.' Global and Planetary Change 148: 42-54. https://doi. org/10.1016/j.gloplacha.2016.11.012.

Duca, G., Chirică, L., Toderaş I. and Teleuţă, A. (eds.) (2015). Cartea Roşie a Republicii Moldova [The Red Book of the Republic of Moldova]. 3rd ed. Î.E.P. Cluj-Napoca: Ştiinţa.

Đug, S., Muratović, E., Drešković, N., Boškailo, A. and Dudević, S. (2013). Crvena Lista Flore Federacije BiH, Knjiga 2. Sarajevo: Federalno ministarstvo okoliša i turizma.

EEA (2010). Red List Index for European Species: Indicator Specification | Data and Maps. Copenhagen: European Environment Agency (EEA). www.eea.europa.eu/dataand-maps/indicators/red-list-index-for-european-species

EMA (2009). Community herbal monograph on Aesculus hippocastanum L., Semen. EMEA/HMPC/225319/2008. London: European Medicines Agency (EMA). https://www. ema.europa.eu/en/documents/herbal-monograph/finalcommunity-herbal-monograph-aesculus-hippocastanum1-semen_en.pdf

Eliáš, P., Dítě, D., Kliment, J., Hrivnák, R. and Feráková, V. (2015). 'Red List of Ferns and Flowering Plants of Slovakia'. Biologia 70(2): 218-228. https://doi.org/10.1515/ biolog-2015-0018

Ellison, A.M., Bank, M.S., Clinton, B.D., Colburn, E.A., Elliott, K., Ford, C.R., Foster, D.R., Kloeppel, B.D., Knoepp, J.D., Lovett, G.M., Mohan, J., Orwig, D.A., Rodenhouse, N.L., Sobczak, W.V., Stinson, K.A., Stone, J.K., Swan, C.M., Thompson, J., Von Holle, B. and Webster, J.R. (2005). 'Loss of foundation species: consequences for the structure and dynamics of forested ecosystems'. Frontiers in Ecology and the Environment 3(9): 479-486.

Euro+Med PlantBase (2006). Euro+Med PlantBase - the Information Resource for Euro-Mediterranean Plant Diversity. Berlin: Botanic Garden and Botanical Museum Berlin-Dahlem. http://ww2.bgbm.org/EuroPlusMed/

European Commission (2015). Harmful Organisms in the European Union. European Commission. Luxembourg: Publications Office of the European Union. https://doi. org/10.2772/59798

_ (2016). 'How Much Biodiversity Does Natura 2000 Cover?' Nature and Biodiversity Newsletter 40: 3-6.

Fontinha, S., Henriques, D., Nóbrega, H., Teixeira, D., Ferro, A. and Carvalho, M.A.A.P. de. (2014). 'Vegetation recovery after a large forest fire in the Ecological Park of Funchal (Madeira Island, Portugal).' Silva Lusitana 22(2): 207-229.

Freyhof, J. and Brooks E. (2011). European Red List of Freshwater Fishes. Luxembourg: Publications Office of the European Union. https://doi.org/10.2779/85903

García Criado, M., Väre, H., Nieto, A., Bento Elias, R., Dyer, R., Ivaneko, Y., Ivanova, D., Lansdown, R., Molina, J.A., Rouhan, G., Rumsey, F., Troia, A., Vrba, J. and Christenhusz, M.J.M. (2017). European Red List of Lycopods and Ferns. Brussels, Belgium: IUCN. https://doi. org/10.2305/IUCN.CH.2017.ERL.1.en

GBIF (2017). Global Biodiversity Information Facility. Copenhagen: Global Biodiversity Information Facility (GBIF). http://gbif.org

Gallardo, M., Gómez, I., Vilar, L., Martínez-Vega, J. and Martín, M.P. (2016). 'Impacts of future land use/land cover on wildfire occurrence in the Madrid region (Spain)'. Regional Environmental Change 16: 1047-1061. https:// doi.org/10.1007/s10113-015-0819-9

Government of Albania (2013). Red List of Wild Flora and Fauna, Albania. Tirana: Approved by Ministerial Order 1280, 20.1.2013.

Grulich, V. (2012). 'Red List of Vascular Plants of the Czech Republic'. Preslia 84(3): 631-645.

Guimarães, A. and Olmeda, C. (2008). Management of Natura 2000 habitats. ${ }^{*}$ Macaronesian Laurel Forests (Laurus, Ocotea). 9360. Technical Report 2008 23/24. European Commission. http://ec.europa.eu/environment/ nature/natura2000/management/habitats/pdf/9360_ Macaronesian_laurel_forests.pdf

Henriksen, S. and Hilmo, O. (2015). Norsk Rødliste for Arter 2015. Norge: Artsdatabanken.

Hochkirch, A., Nieto A., García Criado, M., Cálix, M., Braud, Y., Buzzetti, F.M., Chobanov, D., Odé, B., Presa Asensio, J.J., Willemse, L., Zuna-Kratky, T., Barranco Vega, P., Bushell, M., Clemente, M.E., Correas, J.R., Dusoulier, 
F., Ferreira, S., Fontana, P., García, M.D., Heller, K.-G., Iorgu, I.Ș., Ivković, S., Kati, V., Kleukers, R., Krištín, A., Lemonnier-Darcemont, M., Lemos, P., Massa, B., Monnerat, C., Papapavlou, K.P., Prunier, F., Pushkar, T., Roesti, C., Rutschmann, F., Şirin, D., Skejo, J., Szövényi, G., Tzirkalli, E., Vedenina, V., Barat Domenech, J., Barros, F., Cordero Tapia, P.J., Defaut, B., Fartmann, T., Gomboc, S., Gutiérrez-Rodríguez, J., Holuša, J., Illich, I., Karjalainen, S., Kočárek, P., Korsunovskaya, O., Liana, A., López, H., Morin, D., Olmo-Vidal, J.M., Puskás, G., Savitsky, V., Stalling, T. and Tumbrinck, J. (2016). European Red List of Grasshoppers, Crickets and Bush-Crickets. Luxembourg: Publications Office of the European Union. https://doi. org/10.2779/60944

Hodgetts, N., Cálix, M., Englefield, E., Fettes, N., García Criado, M., Patin, L., Nieto, A., Bergamini, A., Bisang, I., Baisheva, E., Campisi, P., Cogoni, A., Hallingbäck, T., Konstantinova, N., Lockhart, N., Sabovljevic, M., Schnyder, N., Schröck, C., Sérgio, C., Sim Sim, M., Vrba, J., Ferreira, C.C., Afonina, O., Blockeel, T., Blom, H., Caspari, S., Gabriel, R., Garcia, C., Garilleti, R., González Mancebo, J., Goldberg, I., Hedenäs, L., Holyoak, D., Hugonnot, V., Huttunen, S., Ignatov, M., Ignatova, E., Infante, M., Juutinen, R., Kiebacher, T., Köckinger, H., Kučera, J., Lönnell, N., Lüth, M., Martins, A., Maslovsky, O., Papp, B., Porley, R., Rothero, G., Söderström, L., Ştefănuţ, S., Syrjänen, K., Untereiner, A., Váňa, J.I., Vanderpoorten, A., Vellak, K., Aleffi, M., Bates, J., Bell, N., Brugués, M., Cronberg, N., Denyer, J., Duckett, J., During, H.J., Enroth, J., Fedosov, V., Flatberg, K.-I., Ganeva, A., Gorski, P., Gunnarsson, U., Hassel, K., Hespanhol, H., Hill, M., Hodd, R., Hylander, K., Ingerpuu, N., Laaka-Lindberg, S., Lara, F., Mazimpaka, V., Mežaka, A., Müller, F., Orgaz, J.D., Patińo, J., Pilkington, S., Puche, F., Ros, R.M., Rumsey, F., Segarra-Moragues, J.G., Seneca, A., Stebel, A., Virtanen, R., Weibull, H., Wilbraham, J. and Żarnowiec, J. (2019). A miniature world in decline: European Red List of Mosses, Liverworts and Hornworts. Brussels, Belgium: IUCN.

Horvat, I., Glavač, V. and Ellenberg, H. (1974). Vegetation Südosteuropas. Stuttgart: Gustav Fischer.

Ioras, F., Vasile Abrudan, I., Dautbasic, M., Avdibegovic, M., Gurean, D. and Ratnasingam, J. (2009). 'Conservation Gains through HCVF Assessments in Bosnia-Herzegovina and Romania'. Biodiversity and Conservation 18(13): 33953406. https://doi.org/10.1007/s10531-009-9649-8

IUCN (2012a). Guidelines for Application of IUCN Red List Criteria at Regional and National Levels. Version 4.0. Gland, Switzerland: IUCN Species Survival Commission, International Union for Conservation of Nature (IUCN).
_ (2012b). IUCN Red List Categories and Criteria: Version 3.1. Second Edition. Gland, Switzerland: IUCN Species Survival Commission.

_ (2014). METADATA: Digital Distribution Maps on The IUCN Red List of Threatened Species ${ }^{T M}$. Version 4. Cambridge, UK: IUCN.

IUCN Conservation Monitoring Centre (1983). List of Rare, Threatened and Endemic Plants in Europe (1982 Edition). Nature and Environment Series. Strasbourg: Council of Europe. http://www.biodiversitylibrary.org/ item/97612\#page/2/mode/1up

IUCN, Threatened Plants Committee (1977). List of Rare, Threatened and Endemic Plants in Europe. Strasbourg: Council of Europe.

Jankun, A. (1993). 'Znaczenie Apomiksji w Ewolucji Rodzaju Sorbus [Rosaceae]'. Fragmenta Floristica et Geobotanica 38(2): 627-686.

Janssen, J.A.M., Rodwell, J.S., García Criado, M., Gubbay, S., Haynes, T., Nieto, A., Sanders, N., Landucci, F., Loidi, J., Ssymank, A., Tahvanainen, T., Valderrabano, M., Acosta, A., Aronsson, M., Arts, G., Attorre, F., Bergmeier, E., Bijlsma, R.-J., Bioret, F., Biţă-Nicolae, C., Biurrun, I., Calix, M., Capelo, J., Čarni, A. Poulos, P., Essl, F., Gardf, Chytrý, M., Dengler, J., Dimojell, H., Gigante, D., Giusso del Galdo, G., Hájek, M., Jansen, F., Jansen, J., Kapfer, J., Mickolajczak, A., Molina, J.A., Molnár, Z., Paternoster, D., Piernik, A., Poulin, B., Renaux, B., Schaminée, J.H.J., Šumberová, K., Toivonen, H., Tonteri, T., Tsiripidis, I., Tzonev, R. and Valachovič, M. (2016). European Red List of Habitats. Part 2. Terrestrial and freshwater habitats. Luxembourg: Publications Office of the European Union. https://doi.org/10.2779/091372

JNCC (2010). UK Priority Species Data Collation: Juniperus communis. Species Pages For 2007 UK BAP Priority Species. Peterborough: Joint Nature Conservation Council (JNCC).

Kachanovskiy, I.M., Nikiforov, M.E. and Parfionov, V.I. (2015). Red Data Book of the Republic of Belarus: Rare and Threatened Plants of Native Species. 4th ed. Minsk: Pietras Brovka Belarussian encyclopaedia.

Kadis, K., Thanos, C.A. and Laguna, E. (2013). Plant MicroReserves: From Theory to Practice. Athens: Utopia Publishing. Kalkman, V.J., Boudot, J.-P., Bernard, R., Conze, K.-J., De Knijf, G., Dyatlova, E., Ferreira, S., Jović, M., Ott, J., Riservato, E. and Sahlén, G. (2010). European Red List of Dragonflies. Luxembourg: Publications Office of the European Union. https://doi.org/10.2779/84650

Király, G. (2007). Vörös Lista-A Magyarországi Edényes Flóra Veszélyeztetett Fajai [Red List of the Vascular Flora of Hungary]. Saját Kiadás, Sopron, pp73. 
Kozlowski, G. and Gratzfeld. J. (2013). Zelkova - an Ancient Tree. Global Status and Conservation Action. Switzerland: Natural History Museum Fribourg.

Kurtto, A., Sennikov, A. and Lampinen, R. (eds.) (2013). Atlas Florae Europaeae. Vol. 16. Helsinki: The Committee for Mapping the Flora of Europe \& Societas Biologica Fennica Vanamo.

Laguna, E., Fos, S., Jiménez, J. and Volis, S. (2016). 'Role of micro-reserves in conservation of endemic, rare and endangered plants of the Valencian Region (Eastern Spain)'. Israel Journal of Plant Sciences 63(4): 320-332. https://doi.org/10.1080/07929978.2016.1256131

Lanfranco, E. (1989). 'The Flora'. In: P.J. Schembri and J. Sultana. Red Data Book for the Maltese Islands. Malta: Department of Information.

Liebhold, A.M, Brockerhoff, E.G., Garrett, L.J., Parke, J.L. and Britton K.O. (2012). 'Live Plant Imports: The Major Pathway for Forest Insect and Pathogen Invasions of the US'. Frontiers in Ecology and the Environment 10(3): 135143. https://doi.org/10.1890/110198

Lilleleht, V. (ed.) (2008). Eesti Punane Raamat [Red Data Book of Estonia]. Tartu: Commission for Nature Conservation of the Estonian Academy of Sciences.

Lindner, M., Fitzgerald, J.B., Zimmermann, N.E., Reyer, C., Delzon, S., Maaten, E. van der, Schelhaas, M.-J., Lasch, P., Eggers, J., Maaten-Theunissen, M. van der, Suckow, F., Psomas, A., Poulter, B. and Hanewinkel, M. (2014). 'Climate change and European forests: What do we know, what are the uncertainties, and what are the implications for forest management?'. Journal of Environmental Management 146: 69-83. https://doi.org/10.1016/j. jenvman.2014.07.030

Ludwig, G. and Schnittler, M. (1996). Red List of Threatened Plants in Germany [Rote Liste Gefährdeter Pflanzen Deutschlands]. Bonn: Bundesamt für Naturschutz.

Ludwig, S., Robertson, R., Rich, T.C.G., Djordjević, M., Cerović, R., Houston, L., Harris, S.A. and Hiscock, S.J. (2013). 'Breeding systems, hybridization and continuing evolution in Avon Gorge Sorbus'. Annals of Botany 111(4): 563-75. https://doi.org/10.1093/aob/mct013

Maesano, M., Lasserre, B., Masiero, M., Tonti, D. and Marchetti, M. (2016). First Mapping of the Main High Conservation Value Forests (HCVFs) at National Scale: The Case of Italy. Plant Biosystems - An International Journal Dealing with All Aspects of Plant Biology 150(2): 208-216. https://doi.org/10.1080/11263504.2014.948524

Médail, F. and Diadema, K. (2009). 'Glacial refugia influence plant diversity patterns in the Mediterranean Basin'. Journal of Biogeography 36(7): 1333-1345. https://doi. org/10.1111/j.1365-2699.2008.02051.x
Médail, F. and Quezel, P. (1997). 'Hot-Spots Analysis for Conservation of Plant Biodiversity in the Mediterranean Basin'. Annals of the Missouri Botanical Garden 84(1): 112. https://doi.org/10.2307/2399957

Médail, F., Monnet, A.-C., Pavon, D., Nikolić, T., Dimopoulos, P., Bacchetta, G., Barina, Z., Albassatneh, M.C., Domina, G., Fady, B., Matevski, V., Mifsud, S. and Leriche, A. (2019). 'What is a tree in the Mediterranean Basin hotspot? A critical analysis'. Forest Ecosystems 17: https://doi.org/10.1186/s40663-019-0170-6

Medina-Villar, S., Castro-Díez, P., Alonso, A., Cabra-Rivas, I., Parker, I.M. and Pérez-Corona, E. (2015). 'Do the invasive trees, Ailanthus altissima and Robinia pseudoacacia, alter litterfall dynamics and soil properties of riparian ecosystems in Central Spain?'. Plant and Soil 396(1-2): 311-324. https://doi.org/10.1007/s11104-015-2592-4

Meier, E.S., Lischke, H., Schmatz, D.R. and Zimmermann, N.E. (2011). 'Climate, competition and connectivity affect future migration and ranges of European trees'. Global Ecology and Biogeography 21(2): 164-178. https://doi. org/10.1111/j.1466-8238.2011.00669.x

Millar, C.I. and Stephenson, N.L. (2015). 'Temperate forest health in an era of emerging megadisturbance.' Science 349 (6250): 823-826. https://doi.org/10.1126/science.aaa9933

Mirek, Z., Zarzycki, K., Wojewoda, W. and Szeląg, Z. (eds.) (2006). Red List of Plants and Fungi in Poland. Kraków: W. Szafer Institute of Botany, Polish Academy of Sciences. Moser, B.R., Gygax, A., Bäumler, B., Wyler, N. and Palese, R. (2002). Red List of Threatened Ferns and Flowering Plants in Switzerland. OFEFP, Berne.

Náttúrufræðistofnun Islands (1996). Válisti 1 - Plöntur. Iceland: Náttúrufræðistofnun Islands.

(2008). Red List of Vascular Plants. Iceland: Náttúrufræðistofnun Íslands. http://www.ni.is/midlun/ utgafa/valistar/plontur/valisti-aedplantna

Navarro, G., Caballero, I., Silva, G., Parra, P., Vázquez. À. and Caldeira, R. (2017). 'Evaluation of forest fire on Madeira Island using Sentinel 2A MS Imagery'. International Journal of Applied Earth Observation and Geoinformation 58: 97-106. https://doi.org/10.1016/j.jag.2017.02.003

NERI (2007). The Danish Red Data Book. Aarhus: Denmark National Environmental Research Institute.

Neubert, E., Seddon, M.B., Allen, D.J., Arrébola, J., Backeljau, T., Balashov, I., Bank, R., Cameron, R., de Frias Martins, A.M., De Mattia, W., Dedov, I., Duda, M., Falkner, G., Falkner, M., Fehér, Z., Gargominy, O., Georgiev, D., Giusti, F., Gómez Moliner, B.J., Groh, K., Ibáñez, M., Kappes, H., Manganelli, G., Martinez-Orti,, A., Nardi, G., Neiber, M.T., Páll-Gergely, B., Parmakelis, A., Prié, V., Reischütz, A., Reischütz, P.L., Rowson, B., Rüetschi, 
J., Slapnik, R., Son, M., Štamol, V., Teixeira, D., Triantis, K., Vardinoyannis, K., von Proschwitz, T. and Walther, F. (2019). European Red List of Terrestrial Molluscs. IUCN: Cambridge, UK and Brussels, Belgium. https://portals. iucn.org/library/node/48439

Newton, A., Oldfield, S., Rivers, M., Mark, J., Schatz, G., Tejedor Garavito, N., Cantarello, E., Golicher, D., Cayuela, L. and Miles, L. (2015). 'Towards a Global Tree Assessment'. Oryx 49(3): 410-415. https://doi. org/10.1017/S0030605315000137

Nieto, A. and Alexander, K.N.A. (2010). European Red List of Saproxylic Beetles. Luxembourg: Publications Office of the European Union. https://doi.org/10.2779/84561

Nieto, A., Ralph, G.M., Comeros-Raynal, M.T., Heessen, H.J.L. and Rijnsdorp, A.D. (2015). European Red List of Marine Fishes. Luxembourg: Publications Office of the European Union. https://doi.org/10.2779/082723

Nieto, A., Roberts, S.P.M., Kemp, J., Rasmont, P., Kuhlmann, M., García Criado, M., Biesmeijer, J.C., Bogusch, P., Dathe, H.H., De la Rúa, P., De Meulemeester, T., Dehon, M., Dewulf, A., Ortiz-Sánchez, F.J., Lhomme, P., Pauly, A., Potts, S.G., Praz, C., Quaranta, M., Radchenko, V.G., Scheuchl, E., Smit, J., Straka, J., Terzo, M., Tomozii, B., Window, J. and Michez, D. (2014). European Red List of Bees. Luxembourg: Publication Office of the European Union. https://doi.org/10.2779/51181

Niklfeld, H. and Schratt-Ehrendorfer, L. (1999). Rote Liste Gefährdeter Farn- Und Blütenpflanzen (Pteridophyta Und Spermatophyta) Österreichs. 2. Fassung. In: H. Niklfeld (ed.). Rote Listen Gefährdeter Pflanzen Österreichs. 2nd edition. Wein: Grüne Reihe des Bundesministeriums für Umwelt, Jugend und Familie 10.

Nikolić, T. and Topić, J. (2005). Red Book of Vascular Flora of Croatia. Ministarstvo Kulture, Državni Zavod Za Zaštitu Prirode, Zagreb.

Pausas, J.G. and Fernández-Muñoz, S. (2012). 'Fire regime changes in the Western Mediterranean Basin: from fuellimited to drought-driven fire regime'. Climatic Change 110: 215-226. https://doi.org/10.1007/s10584-0110060-6

Pautasso, M., Aas, G., Queloz, V. and Holdenrieder, O. (2013). 'European Ash (Fraxinus excelsior) dieback - A conservation biology challenge'. Biological Conservation 158: 37-49. https://doi.org/10.1016/j.biocon.2012.08.026

Peev, D., Vladimirov, V., Petrova, A.S., Anchev, M., Temniskova-Topalova, D.N., Mitev Denchev, C., Ganeva, A. and Gussev, C. (2015). Red Data Book of the Republic of Bulgaria. Volume 1. Plants and Fungi. Sofia: Bulgarian Academy of Sciences \& Ministry of Environment and Waters.
Petrova, A. and Vladimirov, V. (eds.) (2009). 'Red List of Bulgarian Vascular Plants'. Phytologia Balcanica 15(1): 6394.

Phitos, D., Strid, A., Snogerup, S. and Greuter, W. (eds.) (1995). The Red Data Book of Rare and Threatened Plants of Greece. Athens: WWF-Greece.

Plantlife (2010). Important Plant Areas around the World: Target 5 of the CBD Global Strategy for Plant Conservation. Salisbury, UK: Plantlife International.

Porté, A.J., Lamarque, L.J., Lortie, C.J., Michalet, R. and Delzon, S. (2011). 'Invasive Acer negundo outperforms native species in non-limiting resource environments due to its higher phenotypic plasticity'. BMC Ecology 11: 28. https://doi.org/10.1186/1472-6785-11-28

Rašomavičius, V. (ed.) (2007). Lietuvos Raudonoji Knyga. Vilnius: Lietuvos Respublikos aplinkos ministerija.

Rassi, P., Hyvärinen, E., Juslén, A. and Mannerkoski, I. (eds.) (2010). The 2010 Red List of Finnish Species. Helsinki: Ympäristöministeriö ja Suomen ympäristökeskus [Ministry of the Environment and Finnish Environment Institute].

Rigo, D. de, Libertà, G., Houston Durrant, T., Artés Vivancos, T. and San-Miguel-Ayanz, J. (2017). Forest fire danger extremes in Europe under climate change: variability and uncertainty. Joint Research Centre: Luxembourg: Publications Office of the European Union. https://doi. org/10.2760/13180

Rigo, D. de, Caudullo, G., San-Miguel-Ayanz, J. and Barredo, J.I. (2017). Robust modelling of the impacts of climate change on the habitat suitability of forest tree species. Luxembourg: Publications Office of the European Union. https://doi. org/10.2760/296501

Rivers, M.C. (2017). 'The Global Tree Assessment - Red Listing the World's Trees'. BGJournal 14(1): 16-19.

Rivers, M.C. and Beech, E. (2017). 'Genista aetnensis'. The IUCN Red List of Threatened Species 3: e.T79727282A79727286. http://dx.doi.org/10.2305/IUCN.UK.2017-3.RLTS. T79727282A79727286.en.

Rejmánek, M. and Richardson, D. (2013). 'Trees and shrubs as invasive alien species - 2013 update of the global database'. Diversity and Distributions 19: 1093-1094. https:/doi. org/10.1111/ddi.12075

Ronzon, T., and M'Barek, R. (2018). 'Socioeconomic indicators to monitor the EU's bioeconomy in transition'. Sustainability 10(6): 1745. https://doi.org/10.3390/ su10061745

Rossi, G., Montagnani, C., Gargano D., Peruzzi L., Abeli T., Ravera, S., Cogoni, A., Fenu, G., Magrini, S., Gennai, M., Foggi, B., Wagensommer, R.P., Venturella, G., Blasi, C., Raimondo, F.M. and Orsenigo, S. (2013). Lista Rossa Della Flora Spontanea Italiana. 1. Policy Species e Altre 
Specie Minacciate. Comitato Italiano IUCN e Ministero dell'Ambiente e della Tutela del Territorio e del Mare. http://hdl.handle.net/10281/106736

San-Miguel-Ayanz, J., de Rigo, D., Caudullo, G., Houston Durrant, T. and Mauri, A. (eds.) (2016). European Atlas of Forest Tree Species. Luxembourg: Publication Office of the European Union. https://doi.org/10.2788/4251

Seidl, R., Thom, D., Kautz, M., Martin-Benito, D., Peltoniemi, M., Vacchiano, G., Wild, J., Ascoli, D., Petr, M., Honkaniemi, J., Lexer, M., Trotsiuk, V., Mairota, P., Svoboda, M., Fabrika, M., Nagel, T.A. and Reyer, C.P.O. (2017). 'Forest disturbances under climate change'. Nature Climate Change 7:395-402. https://doi.org/10.1038/ nclimate3303

Seebens, H., Blackburn, T.M., Dyer, E.E., Genovesi, P., Hulme, P.E., Jeschke, J.M., Pagad, S., Pysek, P., Winter, M., Arianoutsou, M., Bacher, S., Blasius, B., Brundu, G., Capinha, C., Celesti-Grapow, L., Dawson, W., Dullinger, S., Fuentes, N., Jaeger, H., Kartesz, J., Kenis, M., Kreft, H., Kuehn, I., Lenzner, B., Liebhold, A., Mosena, A., Moser, D., Nishino, M., Pearman, D., Pergl, J., Rabitsch, W., Rojas-Sandoval, J., Roques, A., Rorke, S., Rossinelli, S., Roy, H.E., Scalera, R., Schindler, S., Stajerova, K., Tokarska-Guzik, B., van Kleunen, M., Walker, K., Weigelt, P., Yamanaka, T. and Essl, F. (2017). 'No saturation in the accumulation of alien species worldwide'. Nature Communications 8: 10.1038/ncomms14435. https://doi. org/10.1038/ncomms 14435

Shaw, K., Stritch, L., Rivers, M., Roy, S., Wilson, B. and Govaerts, R. (2014). The Red List of Betulaceae. Richmond, UK: BGCI. http://www.citeulike.org/group/15400/ article/13628742

Shoo, L.P., Hoffmann, A.A., Garnett, S., Pressey, R.L., Williams, Y.M., Taylor, M., Falconi, L., Yates, C.J., Scott, J.K., Alagador, D. and Williams, S.E. (2013). 'Making decisions to conserve species under climate change'. Climatic Change 119(2): 239-46. https://doi.org/10.1007/ s10584-013-0699-2

SILENE (2017). Système d'Information et de Localisation Des Espèces Natives et Envahissantes. Conservatoire Botanique National Méditerranéen de Porquerolles, Conservatoire Botanique National Alpin. http://www.silene.eu/

Skoberne, P. (1996). Rdeci Seznam Ogrozenih Praprotnic in Semenk Slovenije [Red List of Threatened Vascular Plants in Slovenia]. Lubljana.

Spinoni, J., Vogt, J.V., Naumann, G., Barbosa, P. and Dosio, A. (2017). 'Will drought events become more frequent and severe in Europe?' International Journal of Climatology 38(4): 1718-1736. https://doi.org/10.1002/joc.5291
Stevanović, V. (ed.) (1999). The Red Data Book of Flora of Serbia I: Extinct and Critically Endangered Taxa. Belgrade: Institute for Protection of Nature of the Republic of Serbia.

Stocks, J., Buggs, R.J.A. and Lee, S.J. (2017). 'A first assessment of Fraxinus excelsior (Common Ash) susceptibility to Hymenoscyphus fraxineus (Ash dieback) throughout the British Isles'. Scientific Reports 7: DOI:10.1038/s41598017-16706-6. https://doi.org/10.1038/s41598-017$16706-6$

Svenning, J.-C., Fitzpatrick, M.C., Normand, S., Graham, C.H., Pearman, P.B., Iverson, L.R., and Skov, F. (2010). 'Geography, topography, and history affect realizedto-potential tree species richness patterns in Europe'. Ecography 33(6): 1070-80. https://doi.org/10.1111/ j.1600-0587.2010.06301.x

Svenning, J.-C., and Skov, F. (2007). 'Ice Age legacies in the geographical distribution of tree species richness in Europe'. Global Ecology and Biogeography 16(2): 234-45. https://doi.org/10.1111/j.1466-8238.2006.00280.x

Swaay, C. van, Cuttelod, A., Collins, S., Maes, D., López Munguira, M., Šašić, M., Settele, J., Verovnik, R., Verstrael, T., Warren, M., Wiemers, M. and Wynhof, I. (2010). European Red List of Butterflies. Luxembourg: Publications Office of the European Union. https://doi. org/10.2779/83897

Taberlet, P. and Cheddadi, R. (2002). 'Enhanced: quaternary refugia and persistence of biodiversity'. Science 297 (5589): 2009-2010. https://doi.org/10.1126/ science.297.5589.2009

Temple, H.J. and Cox, N.A. (2009). European Red List of Amphibians. Luxembourg: Office for Official Publications of the European Communities. https://doi. org/10.2779/73661

Temple, H.J. and Terry, A. (2007). The Status and Distribution of European Mammals. Luxembourg: Office for Official Publications of the European Communities. https:// portals.iucn.org/library/node/9047

Thompson, J.D. (2005). Plant Evolution in the Mediterranean. Oxford: Oxford University Press. https://doi.org/10.1093/ acprof:oso/9780198515340.001.0001

Trutnev, Y.P. (ed.) (2008). Красная книга Российской Федерации (растения и грибы) [Red Data Book of the Russian Federation (Plants and Fungi)]. Moscow: Tovarischestvo nauchnykh izdanyi KMK.

Tsintides, T., Christodoulou, C.S., Delipetrou, P. and Georghiou, K. (2007). The Red Data Book of the Flora of Cyprus. Lefkosia: Cyprus Forestry Association.

Tubby, K.V. and Webber, J.F. (2010). 'Pests and diseases threatening urban trees under a changing climate'. Forestry 83(4): 451-59. https://doi.org/10.1093/forestry/cpq027 
Tutin, T.G., Heywood, V.H., Burges, N.A., Valentine, D.H., Walters, S.M. and Webb, D.A. (eds.) (1964). Flora Europaea. Cambridge: Cambridge University Press.

Turco, M., von Hardenberg, J., AghaKouchak, A., Llasat, M.C., Provenzale, A. and Trigo, R.M. (2017). 'On the key role of droughts in the dynamics of summer fires in Mediterranean Europe' Scientific Reports 7(81): https:// doi.org/10.1038/s41598-017-00116-9

UICN France, FCBN and MNHN (2012). La Liste Rouge Des Espèces Menacées En France - Chapitre Flore Vasculaire de France Métropolitaine: Premiers Résultats Pour 1000 Espèces, Sous-Espèces et Variétés. Paris, France: Comité français de l'UICN, Fédération des Conservatoires botaniques nationaux, and Muséum national d'histoire naturelle.

Van der Meijden, R., Odé, B., Groen, L.G., Witte, R. and Bal, D. (2000). 'Bedreigde En Kwetsbare Vaatplanten in Nederland. Basisrapport Met Voorstel Voor de Rode Lijst'. Gorteria 26(4): 85-208.

Van Landuyt, W., Vanhecke, L. and Hoste, I. (2006). 'Rode Lijst van de Vaatplanten van Vlaanderen En Het Brussels Hoofdstedelijk Gewest'. In: W. Van Landuyt, I. Hoste, L. Vanhecke, P. Van den Bremt, E. Vercruysse and D. De Beer (eds.). Atlas van de Flora van Vlaanderen En Het Brussels Gewest. Brussels/Meise: NBO en Nationale Plantentuin van België.
Veira, A., Lasslop, G. and Kloster, S. (2016). 'Wildfires in a warmer climate: Emission fluxes, emission heights, and black carbon concentrations in 2090-2099.' Journal of Geophysical Research: Atmospheres 121(7): https://doi. org/10.1002/2015JD024142

Vítková, M., Müllerová, J., Sádlo, J., Pergl, J. and Pyšek, P. (2017). Black locust (Robinia pseudoacacia) beloved and despised: A story of an invasive tree in Central Europe'. Forest Ecology and Management 384: 287-302. https://doi. org/10.1016/j.foreco.2016.10.057

WCSP (2016). World Checklist of Selected Plant Families. Royal Botanic Gardens, Kew. http://wcsp.science.kew.org

Witkowski, Z.J., Król, W. and Solarz, W. (2003). Carpathian List of Endangered Species. WWF and Institute of Nature Conservation, Polish Academy of Sciences, ViennaKrakow.

Wyse Jackson, M., FitzPatrick, Ú., Cole E., Jebb, M., McFerran, D., Sheehy Skeffington, M., and Wright, M. (2016). Ireland Red List No. 10: Vascular Plants. Dublin, Ireland: National Parks and Wildlife Service, Department of Arts, Heritage, Regional, Rural and Gaeltacht Affairs. 


\section{Annex 1}

Full list of tree species assessed, their assessment on a European and EU 28 level, if endemic to Europe and the number of recorded ex situ collections in botanic gardens.

${ }^{*}$ An asterisk indicates that a species was assessed for the EU 27 Member States (pre-2013).

\begin{tabular}{|c|c|c|c|c|c|}
\hline Family & Species & $\begin{array}{l}\text { European Red List } \\
\text { Category and Criteria }\end{array}$ & $\begin{array}{c}\text { EU 28* Red List Category } \\
\text { and Criteria }\end{array}$ & Endemic & $\begin{array}{l}\text { Ex situ } \\
\text { collections }\end{array}$ \\
\hline ANACARDIACEAE & Cotinus coggygria & LC & $\mathrm{LC}^{*}$ & No & 196 \\
\hline ANACARDIACEAE & Pistacia atlantica & $\mathrm{LC}$ & LC & No & 38 \\
\hline ANACARDIACEAE & Pistacia lentiscus & $\mathrm{LC}$ & $\mathrm{LC}^{*}$ & No & 86 \\
\hline ANACARDIACEAE & Pistacia terebinthus & $\mathrm{LC}$ & LC & No & 56 \\
\hline ANACARDIACEAE & Rhus coriaria & $\mathrm{LC}$ & $\mathrm{LC}$ & No & 35 \\
\hline ANACARDIACEAE & Searsia pentaphylla & VU D1 & VU D1 & No & 2 \\
\hline ANACARDIACEAE & Searsia tripartita & VU D1 & VU D1 & No & 1 \\
\hline AQUIFOLIACEAE & Ilex aquifolium & LC & $\mathrm{LC}^{*}$ & No & 178 \\
\hline AQUIFOLIACEAE & Ilex canariensis & LC & LC & Yes & 12 \\
\hline AQUIFOLIACEAE & Ilex perado & $\mathrm{LC}$ & $\mathrm{LC}$ & Yes & 13 \\
\hline BETULACEAE & Alnus alnobetula & $\mathrm{LC}$ & $\mathrm{LC}$ & No & 10 \\
\hline BETULACEAE & Alnus cordata & LC & LC & Yes & 94 \\
\hline BETULACEAE & Alnus glutinosa & $\mathrm{LC}$ & $\mathrm{LC}$ & No & 178 \\
\hline BETULACEAE & Alnus incana & $\mathrm{LC}$ & $\mathrm{LC}$ & No & 98 \\
\hline BETULACEAE & Alnus orientalis & $\mathrm{LC}$ & $\mathrm{LC}$ & No & 17 \\
\hline BETULACEAE & Betula baschkirica & $\mathrm{DD}$ & NA & Yes & 0 \\
\hline BETULACEAE & Betula celtiberica & $\mathrm{DD}$ & $\mathrm{DD}$ & Yes & 12 \\
\hline BETULACEAE & Betula klokovii & CR B1ab(iii,v); C2a(i); D & NA & Yes & 1 \\
\hline BETULACEAE & Betula kotulae & $\mathrm{DD}$ & NA & Yes & 0 \\
\hline BETULACEAE & Betula pendula & LC & LC* $^{*}$ & No & 199 \\
\hline BETULACEAE & Betula pubescens & $\mathrm{LC}$ & $\mathrm{LC}^{*}$ & No & 129 \\
\hline BETULACEAE & Carpinus betulus & $\mathrm{LC}$ & $\mathrm{LC}$ & No & 194 \\
\hline BETULACEAE & Carpinus orientalis & $\mathrm{LC}$ & $\mathrm{LC}$ & No & 68 \\
\hline BETULACEAE & Corylus avellana & $\mathrm{LC}$ & $\mathrm{LC}$ & No & 181 \\
\hline BETULACEAE & Corylus colurna & $\mathrm{LC}$ & $\mathrm{LC}$ & No & 175 \\
\hline BETULACEAE & Corylus maxima & $\mathrm{DD}$ & $\mathrm{DD}^{*}$ & Yes & 40 \\
\hline BETULACEAE & Ostrya carpinifolia & LC & $\mathrm{LC}$ & No & 144 \\
\hline BUXACEAE & Buxus sempervirens & $\mathrm{LC}$ & LC* $^{*}$ & No & 225 \\
\hline CAPRIFOLIACEAE & Lonicera arborea & $\mathrm{LC}$ & $\mathrm{LC}$ & No & 18 \\
\hline CAPRIFOLIACEAE & Lonicera nummulariifolia & LC & LC & No & 10 \\
\hline CAPRIFOLIACEAE & Sambucus lanceolata & VU D1 & VU D1 & Yes & 1 \\
\hline CAPRIFOLIACEAE & Sambucus nigra & LC & LC* & No & 168 \\
\hline CAPRIFOLIACEAE & Viburnum tinus & $\mathrm{LC}$ & $\mathrm{LC}$ & No & 16 \\
\hline CAPRIFOLIACEAE & Viburnum treleasei & $\mathrm{LC}$ & $\mathrm{LC}$ & Yes & 2 \\
\hline CELASTRACEAE & Euonymus europaeus & $\mathrm{LC}$ & $\mathrm{LC}$ & No & 160 \\
\hline CELASTRACEAE & Euonymus latifolius & LC & $\mathrm{LC}$ & No & 75 \\
\hline CELASTRACEAE & Maytenus canariensis & NT & NT & Yes & 14 \\
\hline CELASTRACEAE & Maytenus umbellata & $\mathrm{LC}$ & $\mathrm{LC}$ & Yes & 2 \\
\hline CHENOPODIACEAE & Halostachys belangeriana & $\mathrm{LC}$ & NA & No & 1 \\
\hline CLETHRACEAE & Clethra arborea & $\mathrm{LC}$ & $\mathrm{LC}$ & Yes & 35 \\
\hline COMPOSITAE & Sonchus fruticosus & $\mathrm{LC}$ & $\mathrm{LC}$ & Yes & 9 \\
\hline
\end{tabular}




\begin{tabular}{|c|c|c|c|c|c|}
\hline Family & Species & $\begin{array}{c}\text { European Red List } \\
\text { Category and Criteria }\end{array}$ & $\begin{array}{l}\text { EU 28* Red List Category } \\
\text { and Criteria }\end{array}$ & Endemic & $\begin{array}{c}\text { Ex situ } \\
\text { collections }\end{array}$ \\
\hline COMPOSITAE & Sonchus pinnatus & LC & LC & Yes & 5 \\
\hline CORNACEAE & Cornus mas & LC & LC & No & 233 \\
\hline CUPRESSACEAE & Cupressus sempervirens & LC & LC & No & 161 \\
\hline CUPRESSACEAE & Juniperus brevifolia & VU B2ab(ii,iii,v) & VU B2ab(ii,iii) & Yes & 10 \\
\hline CUPRESSACEAE & Juniperus cedrus & EN B2ab(ii,iii,v); C2a(i) & EN B2ab(ii,iii,v); C2a(i) & Yes & 39 \\
\hline CUPRESSACEAE & Juniperus communis & LC & LC & No & 194 \\
\hline CUPRESSACEAE & Juniperus drupacea & EN B1ab(iii)+2ab(iii) & EN B1ab(iii)+2ab(iii) & No & 29 \\
\hline CUPRESSACEAE & Juniperus excelsa & LC & LC & No & 40 \\
\hline CUPRESSACEAE & Juniperus foetidissima & LC & LC & No & 23 \\
\hline CUPRESSACEAE & Juniperus oxycedrus & LC & LC & No & 57 \\
\hline CUPRESSACEAE & Juniperus phoenicea & LC & LC & Yes & 71 \\
\hline CUPRESSACEAE & Juniperus thurifera & LC & LC & No & 34 \\
\hline CUPRESSACEAE & Juniperus turbinata & NT & NT & No & 0 \\
\hline CUPRESSACEAE & Tetraclinis articulata & EN B2ab(iii) & EN B2ab(iii) & No & 70 \\
\hline DRACAENACEAE & Dracaena draco & EN B2ab(iii) & EN B2ab(iii) & No & 184 \\
\hline DRACAENACEAE & Dracaena tamaranae & CR C2a(i); D & CR C2a(i); D & Yes & 4 \\
\hline ELAEAGNACEAE & Elaeagnus rhamnoides & LC & LC* & No & 5 \\
\hline ERICACEAE & Arbutus andrachne & LC & LC & No & 31 \\
\hline ERICACEAE & Arbutus canariensis & NT & NT & Yes & 31 \\
\hline ERICACEAE & Arbutus unedo & LC & LC $^{*}$ & No & 141 \\
\hline ERICACEAE & Erica arborea & LC & LC & No & 88 \\
\hline ERICACEAE & Vaccinium cylindraceum & LC & LC & Yes & 18 \\
\hline ERICACEAE & Vaccinium padifolium & LC & LC & Yes & 16 \\
\hline EUPHORBIACEAE & Euphorbia dendroides & LC & LC & No & 38 \\
\hline EUPHORBIACEAE & Euphorbia margalidiana & VU D1+2 & VU D1+2 & Yes & 10 \\
\hline EUPHORBIACEAE & Euphorbia mellifera & LC & LC & Yes & 46 \\
\hline FAGACEAE & Castanea sativa & LC & LC $^{*}$ & No & 143 \\
\hline FAGACEAE & Fagus orientalis & LC & LC & No & 69 \\
\hline FAGACEAE & Fagus sylvatica & LC & LC & No & 208 \\
\hline FAGACEAE & Quercus alnifolia & LC & LC & Yes & 20 \\
\hline FAGACEAE & Quercus aucheri & $\mathrm{LC}$ & LC & No & 3 \\
\hline FAGACEAE & Quercus canariensis & NT & NT & No & 50 \\
\hline FAGACEAE & Quercus cerris & LC & LC & No & 149 \\
\hline FAGACEAE & Quercus coccifera & LC & LC & No & 84 \\
\hline FAGACEAE & Quercus congesta & LC & $\mathrm{LC}$ & Yes & 0 \\
\hline FAGACEAE & Quercus crenata & $\mathrm{DD}$ & $\mathrm{DD}$ & Yes & 7 \\
\hline FAGACEAE & Quercus dalechampii & $\mathrm{DD}$ & $\mathrm{DD}$ & Yes & 15 \\
\hline FAGACEAE & Quercus faginea & LC & LC & No & 53 \\
\hline FAGACEAE & Quercus frainetto & LC & LC* & No & 79 \\
\hline FAGACEAE & Quercus hartwissiana & $\mathrm{DD}$ & $\mathrm{DD}$ & No & 37 \\
\hline FAGACEAE & Quercus ichnusae & $\mathrm{LC}$ & $\mathrm{LC}$ & Yes & 0 \\
\hline FAGACEAE & Quercus ilex & LC & LC & No & 147 \\
\hline FAGACEAE & Quercus infectoria & LC & LC & No & 13 \\
\hline FAGACEAE & Quercus ithaburensis & LC & LC & No & 21 \\
\hline FAGACEAE & Quercus lusitanica & LC & LC & No & 18 \\
\hline FAGACEAE & Quercus pauciradiata & $\mathrm{DD}$ & DD & Yes & 0 \\
\hline FAGACEAE & Quercus petraea & LC & LC* $^{*}$ & No & 106 \\
\hline
\end{tabular}




\begin{tabular}{|c|c|c|c|c|c|}
\hline Family & Species & $\begin{array}{c}\text { European Red List } \\
\text { Category and Criteria }\end{array}$ & $\begin{array}{l}\text { EU 28* Red List Category } \\
\text { and Criteria }\end{array}$ & Endemic & $\begin{array}{c}\text { Ex situ } \\
\text { collections }\end{array}$ \\
\hline FAGACEAE & Quercus pubescens & LC & LC & No & 86 \\
\hline FAGACEAE & Quercus pyrenaica & LC & LC & No & 60 \\
\hline FAGACEAE & Quercus robur & LC & LC $^{*}$ & No & 223 \\
\hline FAGACEAE & Quercus rotundifolia & LC & LC & No & 20 \\
\hline FAGACEAE & Quercus suber & LC & LC & No & 136 \\
\hline FAGACEAE & Quercus trojana & LC & LC & No & 45 \\
\hline HAMAMELIDACEAE & Liquidambar orientalis & CR B1ab(ii,iii)+2ab(ii,iii) & CR B1ab(ii,iii)+2ab(ii,iii) & No & 75 \\
\hline JUGLANDACEAE & Juglans regia & LC & LC & No & 163 \\
\hline LAURACEAE & Apollonias barbujana & LC & LC & Yes & 27 \\
\hline LAURACEAE & Laurus azorica & LC & LC & Yes & 47 \\
\hline LAURACEAE & Laurus nobilis & LC & LC $^{*}$ & No & 210 \\
\hline LAURACEAE & Laurus novocanariensis & LC & LC & No & 5 \\
\hline LAURACEAE & Ocotea foetens & LC & LC & Yes & 28 \\
\hline LAURACEAE & Persea indica & LC & LC & Yes & 45 \\
\hline LEGUMINOSAE & Anagyris foetida & LC & LC & No & 27 \\
\hline LEGUMINOSAE & Ceratonia siliqua & LC & LC* & No & 137 \\
\hline LEGUMINOSAE & Cercis siliquastrum & LC & LC & No & 144 \\
\hline LEGUMINOSAE & Cytisus aeolicus & $\begin{array}{c}\text { EN } \\
\text { B1ab(iii,v)+2ab(iii,v); } \\
\text { C2a(i) }\end{array}$ & $\begin{array}{c}\text { EN } \\
\text { Blab(iii,v)+2ab(iii,v); } \\
\text { C2a(i) }\end{array}$ & Yes & 161 \\
\hline LEGUMINOSAE & Cytisus arboreus & LC & LC & No & 1 \\
\hline LEGUMINOSAE & Cytisus proliferus & LC & LC & Yes & 2 \\
\hline LEGUMINOSAE & Genista aetnensis & LC & LC & Yes & 42 \\
\hline LEGUMINOSAE & Genista maderensis & LC & LC & Yes & 4 \\
\hline LEGUMINOSAE & Genista thyrrena & LC & LC & Yes & 2 \\
\hline LEGUMINOSAE & Laburnum alpinum & LC & LC & Yes & 84 \\
\hline LEGUMINOSAE & Laburnum anagyroides & LC & LC & Yes & 124 \\
\hline LEGUMINOSAE & Medicago citrina & EN B2ab(ii,iii,v) & EN B2ab(ii,iii,v) & Yes & 5 \\
\hline MALVACEAE & Tilia cordata & LC & LC* & No & 189 \\
\hline MALVACEAE & Tilia dasystyla & LC & NA & No & 41 \\
\hline MALVACEAE & Tilia platyphyllos & LC & LC $^{*}$ & Yes & 132 \\
\hline MALVACEAE & Tilia tomentosa & LC & LC* & No & 128 \\
\hline MORACEAE & Ficus carica & LC & LC & No & 184 \\
\hline MYRICACEAE & Morella faya & LC & LC & Yes & 2 \\
\hline MYRICACEAE & Morella rivas-martinezii & CR B2ab(iii,v) & CR B2ab(iii,v)* & Yes & 2 \\
\hline MYRSINACEAE & Heberdenia excelsa & VU C1 & VU C1 & Yes & 6 \\
\hline MYRSINACEAE & Pleiomeris canariensis & CR C2a(i) & CR C2a(i) & Yes & 3 \\
\hline MYRTACEAE & Myrtus communis & LC & LC* & No & 150 \\
\hline OLEACEAE & Fraxinus angustifolia & LC & LC $^{*}$ & No & 80 \\
\hline OLEACEAE & Fraxinus excelsior & NT & $\mathrm{NT}^{*}$ & No & 179 \\
\hline OLEACEAE & Fraxinus ornus & $\mathrm{LC}$ & LC & No & 164 \\
\hline OLEACEAE & Fraxinus pallisiae & $\mathrm{DD}$ & $\mathrm{DD}$ & No & 6 \\
\hline OLEACEAE & Olea europaea & DD & $\mathrm{DD}$ & No & 135 \\
\hline OLEACEAE & Olea maderensis & LC & LC & Yes & 1 \\
\hline OLEACEAE & Phillyrea latifolia & $\mathrm{LC}$ & LC & No & 84 \\
\hline OLEACEAE & Picconia azorica & $\mathrm{LC}$ & LC & Yes & 16 \\
\hline OLEACEAE & Picconia excelsa & LC & LC & Yes & 22 \\
\hline OLEACEAE & Syringa vulgaris & LC & LC & Yes & 172 \\
\hline
\end{tabular}




\begin{tabular}{|c|c|c|c|c|c|}
\hline Family & Species & $\begin{array}{c}\text { European Red List } \\
\text { Category and Criteria }\end{array}$ & $\begin{array}{l}\text { EU 28* Red List Category } \\
\text { and Criteria }\end{array}$ & Endemic & $\begin{array}{c}\text { Ex situ } \\
\text { collections }\end{array}$ \\
\hline PALMAE & Chamaerops humilis & LC & LC & No & 172 \\
\hline PALMAE & Phoenix canariensis & LC & LC & Yes & 145 \\
\hline PALMAE & Phoenix theophrasti & NT & NT & No & 50 \\
\hline PENTAPHYLACACEAE & Visnea mocanera & LC & LC & Yes & 33 \\
\hline PINACEAE & Abies alba & LC & LC & Yes & 129 \\
\hline PINACEAE & Abies cephalonica & $\mathrm{LC}$ & $\mathrm{LC}$ & Yes & 103 \\
\hline PINACEAE & Abies nebrodensis & CR A2cd; D & CR A2cd; D & Yes & 49 \\
\hline PINACEAE & Abies pinsapo & EN B1ab(iii)+2ab(iii) & EN (B1ab(iii)+2ab(iii)) & No & 128 \\
\hline PINACEAE & Cedrus libani & VU D2 & VU D2 & No & 132 \\
\hline PINACEAE & Larix decidua & LC & LC & Yes & 172 \\
\hline PINACEAE & Picea abies & LC & LC & Yes & 228 \\
\hline PINACEAE & Picea obovata & LC & NA & No & 69 \\
\hline PINACEAE & Picea omorika & EN B1ab(i,iii,v)+2ab(i,ii,v) & $\mathrm{NA}$ & Yes & 203 \\
\hline PINACEAE & Pinus brutia & LC & LC & No & 43 \\
\hline PINACEAE & Pinus canariensis & LC & LC & Yes & 69 \\
\hline PINACEAE & Pinus cembra & LC & LC & Yes & 154 \\
\hline PINACEAE & Pinus halepensis & LC & LC & No & 86 \\
\hline PINACEAE & Pinus heldreichii & LC & LC & Yes & 78 \\
\hline PINACEAE & Pinus mugo & LC & LC & Yes & 171 \\
\hline PINACEAE & Pinus nigra & LC & LC & No & 180 \\
\hline PINACEAE & Pinus peuce & NT & VU B1ab(ii)B2ab(iii)) & Yes & 102 \\
\hline PINACEAE & Pinus pinaster & LC & LC & No & 93 \\
\hline PINACEAE & Pinus pinea & LC & LC & No & 130 \\
\hline PINACEAE & Pinus sylvestris & LC & LC & No & 208 \\
\hline PINACEAE & Pinus uncinata & LC & LC & Yes & 45 \\
\hline PITTOSPORACEAE & Pittosporum coriaceum & CR D & CR D* & Yes & 8 \\
\hline PLATANACEAE & Platanus orientalis & VU A3ce+4ce & VU A3ce+4ce & No & 100 \\
\hline RHAMNACEAE & Frangula alnus & LC & LC* & No & 87 \\
\hline RHAMNACEAE & Frangula azorica & LC & LC & Yes & 6 \\
\hline RHAMNACEAE & Rhamnus alaternus & LC & LC & No & 45 \\
\hline RHAMNACEAE & Rhamnus alpina & LC & LC & No & 19 \\
\hline RHAMNACEAE & Rhamnus cathartica & LC & LC & No & 108 \\
\hline RHAMNACEAE & Rhamnus glandulosa & LC & LC & Yes & 10 \\
\hline RHAMNACEAE & Rhamnus lojaconoi & CR D & CR D & Yes & 0 \\
\hline RHAMNACEAE & Rhamnus persicifolia & EN B1ab(iii,v)+2ab(iii,v) & EN B1ab(iii,v)+2ab(iii,v) & Yes & 3 \\
\hline ROSACEAE & Chamaemeles coriacea & EN B1ab(iii)+2ab(iii); D & EN B1ab(iii)+2ab(iii); D & Yes & 1 \\
\hline ROSACEAE & Crataegus ambigua & LC & NA & No & 28 \\
\hline ROSACEAE & Crataegus azarolus & LC & $\mathrm{LC}^{*}$ & No & 48 \\
\hline ROSACEAE & Crataegus chlorocarpa & LC & NA & No & 6 \\
\hline ROSACEAE & Crataegus heldreichii & LC & LC & Yes & 7 \\
\hline ROSACEAE & Crataegus laciniata & NT & NT & No & 25 \\
\hline ROSACEAE & Crataegus laevigata & LC & LC & Yes & 77 \\
\hline ROSACEAE & Crataegus meyeri & $\mathrm{DD}$ & NA & No & 11 \\
\hline ROSACEAE & Crataegus monogyna & LC & LC $^{*}$ & No & 159 \\
\hline ROSACEAE & Crataegus nigra & $\begin{array}{l}\text { EN A2ac; B1ab(i,iii,iii,iv,v) } \\
+2 \mathrm{ab}(\mathrm{i}, \mathrm{ii}, \mathrm{iii}, \mathrm{iv}, \mathrm{v})\end{array}$ & $\begin{array}{c}\text { EN A2ac; B1ab(i,iii,iii,iv,v)+ } \\
\text { 2ab(i,ii,iii,iv,v) }\end{array}$ & Yes & 26 \\
\hline ROSACEAE & Crataegus pentagyna & $\mathrm{DD}$ & $\mathrm{DD}^{*}$ & No & 26 \\
\hline
\end{tabular}




\begin{tabular}{|c|c|c|c|c|c|}
\hline Family & Species & $\begin{array}{l}\text { European Red List } \\
\text { Category and Criteria }\end{array}$ & $\begin{array}{c}\text { EU 28* Red List Category } \\
\text { and Criteria }\end{array}$ & Endemic & $\begin{array}{l}\text { Ex situ } \\
\text { collections }\end{array}$ \\
\hline ROSACEAE & Crataegus pycnoloba & LC & $\mathrm{LC}$ & Yes & 3 \\
\hline ROSACEAE & Crataegus rhipidophylla & LC & LC & No & 9 \\
\hline ROSACEAE & Crataegus sphaenophylla & NT & NA & Yes & 1 \\
\hline ROSACEAE & Malus crescimannoi & $\mathrm{DD}$ & $\mathrm{DD}^{*}$ & Yes & 1 \\
\hline ROSACEAE & Malus dasyphylla & $\mathrm{DD}$ & $\mathrm{DD}^{*}$ & Yes & 0 \\
\hline ROSACEAE & Malus florentina & $\mathrm{DD}$ & $\mathrm{DD}^{*}$ & No & 32 \\
\hline ROSACEAE & Malus sylvestris & $\mathrm{DD}$ & $\mathrm{DD}^{*}$ & Yes & 85 \\
\hline ROSACEAE & Malus trilobata & $\mathrm{LC}$ & LC* $^{*}$ & No & 30 \\
\hline ROSACEAE & Marcetella moquiniana & EN B2ab(iii) & EN B2ab(iii) & Yes & 25 \\
\hline ROSACEAE & Mespilus germanica & $\mathrm{LC}$ & $\mathrm{LC}$ & No & 118 \\
\hline ROSACEAE & Prunus avium & $\mathrm{LC}$ & $\mathrm{LC}^{*}$ & No & 123 \\
\hline ROSACEAE & Prunus brigantina & $\mathrm{DD}$ & $\mathrm{DD}^{*}$ & Yes & 18 \\
\hline ROSACEAE & Prunus cerasifera & $\mathrm{DD}$ & $\mathrm{DD}^{*}$ & No & 92 \\
\hline ROSACEAE & Prunus cocomilia & $\mathrm{DD}$ & $\mathrm{DD}^{*}$ & No & 16 \\
\hline ROSACEAE & Prunus discolor & $\mathrm{DD}$ & $\mathrm{DD}^{*}$ & No & 0 \\
\hline ROSACEAE & Prunus domestica & $\mathrm{DD}$ & $\mathrm{DD}$ & No & 56 \\
\hline ROSACEAE & Prunus laurocerasus & LC & $\mathrm{LC}^{*}$ & No & 142 \\
\hline ROSACEAE & Prunus lusitanica & VU B2ab(ii,v) & VU B2ab(ii,v)* & No & 92 \\
\hline ROSACEAE & Prunus mahaleb & $\mathrm{LC}$ & $\mathrm{LC}^{*}$ & No & 79 \\
\hline ROSACEAE & Prunus padus & LC & LC* $^{*}$ & No & 117 \\
\hline ROSACEAE & Prunus prostrata & $\mathrm{DD}$ & $\mathrm{DD}^{*}$ & No & 21 \\
\hline ROSACEAE & Prunus ramburii & VU C2a(i); D2 & VU C2a(i); D2* & Yes & 6 \\
\hline ROSACEAE & Prunus spinosa & LC & $\mathrm{LC}^{*}$ & No & 130 \\
\hline ROSACEAE & Prunus webbii & $\mathrm{DD}$ & $\mathrm{DD}^{*}$ & No & 5 \\
\hline ROSACEAE & Pyrus bourgaeana & $\mathrm{LC}$ & $\mathrm{LC}^{*}$ & No & 9 \\
\hline ROSACEAE & Pyrus castribonensis & $\mathrm{LC}$ & $\mathrm{LC}$ & Yes & 0 \\
\hline ROSACEAE & Pyrus ciancioi & $\mathrm{DD}$ & DD & Yes & 0 \\
\hline ROSACEAE & Pyrus communis & LC & LC* & No & 119 \\
\hline ROSACEAE & Pyrus cordata & $\mathrm{DD}$ & $\mathrm{DD}^{*}$ & No & 19 \\
\hline ROSACEAE & Pyrus elaeagrifolia & $\mathrm{DD}$ & $\mathrm{DD}^{*}$ & No & 15 \\
\hline ROSACEAE & Pyrus nivalis & DD & $\mathrm{DD}^{*}$ & No & 37 \\
\hline ROSACEAE & Pyrus sicanorum & $\mathrm{LC}$ & $\mathrm{LC}$ & Yes & 0 \\
\hline ROSACEAE & Pyrus spinosa & $\mathrm{DD}$ & $\mathrm{DD}^{*}$ & No & 12 \\
\hline ROSACEAE & Pyrus syriaca & LC & $\mathrm{LC}^{*}$ & No & 16 \\
\hline ROSACEAE & Pyrus vallis-demonis & DD & $\mathrm{DD}^{*}$ & Yes & 0 \\
\hline ROSACEAE & Sorbus acutiserrata & CR D & CR D & Yes & 0 \\
\hline ROSACEAE & Sorbus adamii & CR B1ab(iii); D & CR B1ab(iii); D & Yes & 7 \\
\hline ROSACEAE & Sorbus adeana & EN D & EN D & Yes & 1 \\
\hline ROSACEAE & Sorbus admonitor & EN D & EN D & Yes & 3 \\
\hline ROSACEAE & Sorbus albensis & EN B1ab(iii)+2ab(iii) & EN B1ab(iii)+2ab(iii) & Yes & 1 \\
\hline ROSACEAE & Sorbus alnifrons & EN B1ab(iii)+2ab(iii); D & EN B1ab(iii)+2ab(iii); D & Yes & 2 \\
\hline ROSACEAE & Sorbus amici-petri & EN D & EN D & Yes & 0 \\
\hline ROSACEAE & Sorbus andreanszkyana & CR B1ab(iii)+2ab(iii) & CR B1ab(iii)+2ab(iii) & Yes & 2 \\
\hline ROSACEAE & Sorbus anglica & NT & NT & Yes & 25 \\
\hline ROSACEAE & Sorbus aria & LC & LC & No & 129 \\
\hline ROSACEAE & Sorbus arranensis & EN B1ab(iii)+2ab(iii); D & EN B1ab(iii)+2ab(iii); D & Yes & 22 \\
\hline ROSACEAE & Sorbus arvonensis & CR D & CR D & Yes & 0 \\
\hline
\end{tabular}




\begin{tabular}{|c|c|c|c|c|c|}
\hline Family & Species & $\begin{array}{c}\text { European Red List } \\
\text { Category and Criteria }\end{array}$ & $\begin{array}{c}\text { EU 28* Red List Category } \\
\text { and Criteria }\end{array}$ & Endemic & $\begin{array}{c}\text { Ex situ } \\
\text { collections }\end{array}$ \\
\hline ROSACEAE & Sorbus aucuparia & LC & $\mathrm{LC}$ & No & 183 \\
\hline ROSACEAE & Sorbus austriaca & $\mathrm{LC}$ & $\mathrm{LC}$ & Yes & 22 \\
\hline ROSACEAE & Sorbus avonensis & CR D & CR D & Yes & 1 \\
\hline ROSACEAE & Sorbus badensis & VU D1 & VU D1 & Yes & 2 \\
\hline ROSACEAE & Sorbus bakonyensis & CR D & CR D & Yes & 7 \\
\hline ROSACEAE & Sorbus balatonica & VU B1ab(iii)+2ab(iii) & VU B1ab(iii)+2ab(iii) & Yes & 2 \\
\hline ROSACEAE & Sorbus baldaccii & $\mathrm{DD}$ & $\mathrm{DD}$ & Yes & 1 \\
\hline ROSACEAE & Sorbus barabitsii & CR D & CR D1 & Yes & 0 \\
\hline ROSACEAE & Sorbus barrandienica & CR D & CR D & Yes & 1 \\
\hline ROSACEAE & Sorbus bodajkensis & CR D & CR D & Yes & 0 \\
\hline ROSACEAE & Sorbus bohemica & EN C2a(i) & EN C2a(i) & Yes & 2 \\
\hline ROSACEAE & Sorbus borbasii & DD & DD & Yes & 17 \\
\hline ROSACEAE & Sorbus borosiana & CR B1ab(iii)+2ab(iii); D & CR B1ab(iii)+2ab(iii); D & Yes & 3 \\
\hline ROSACEAE & Sorbus bosniaca & EN B1ab(iii) & EN B1ab(iii) & Yes & 0 \\
\hline ROSACEAE & Sorbus bristoliensis & EN D & EN D & Yes & 26 \\
\hline ROSACEAE & Sorbus budaiana & DD & $\mathrm{DD}$ & Yes & 0 \\
\hline ROSACEAE & Sorbus buekkensis & DD & $\mathrm{DD}$ & Yes & 0 \\
\hline ROSACEAE & Sorbus busambarensis & CR D & CR D & Yes & 0 \\
\hline ROSACEAE & Sorbus cambrensis & EN D & EN D & Yes & 3 \\
\hline ROSACEAE & Sorbus cheddarensis & CR D & CR D & Yes & 1 \\
\hline ROSACEAE & Sorbus collina & LC & LC & Yes & 1 \\
\hline ROSACEAE & Sorbus cordigastensis & EN D & EN D & Yes & 2 \\
\hline ROSACEAE & Sorbus croceocarpa & DD & $\mathrm{DD}$ & Yes & 10 \\
\hline ROSACEAE & Sorbus cucullifera & CR B1ab(iii) & CR B1ab(iii) & Yes & 1 \\
\hline ROSACEAE & Sorbus cuneifolia & EN D & EN D & Yes & 2 \\
\hline ROSACEAE & Sorbus danubialis & LC & LC & Yes & 16 \\
\hline ROSACEAE & Sorbus decipientiformis & $\mathrm{DD}$ & $\mathrm{DD}$ & Yes & 1 \\
\hline ROSACEAE & Sorbus degenii & VU B1ab(iii)+2ab(iii); D1 & VU B1ab(iii)+2ab(iii); D1 & Yes & 9 \\
\hline ROSACEAE & Sorbus devoniensis & VU D1 & VU D1 & Yes & 21 \\
\hline ROSACEAE & Sorbus dolomiticola & EN B1ab(iii)+2ab(iii); D & EN B1ab(iii)+2ab(iii); D & Yes & 1 \\
\hline ROSACEAE & Sorbus domestica & LC & LC & No & 85 \\
\hline ROSACEAE & Sorbus dominii & $\mathrm{DD}$ & $\mathrm{DD}$ & Yes & 0 \\
\hline ROSACEAE & Sorbus dracofolia & CR D & CR D & Yes & 0 \\
\hline ROSACEAE & Sorbus eminens & VU D1 & VU D1 & Yes & 10 \\
\hline ROSACEAE & Sorbus eminentiformis & EN D & EN D & Yes & 3 \\
\hline ROSACEAE & Sorbus eminentoides & CR D & CR D & Yes & 1 \\
\hline ROSACEAE & Sorbus engenii-kelleri & VU B1ab(iii)+2ab(iii) & VU B1ab(iii)+2ab(iii) & Yes & 6 \\
\hline ROSACEAE & Sorbus evansii & CR D & CR D & Yes & 1 \\
\hline ROSACEAE & Sorbus eximia & EN B1ab(iii)+2ab(iii); D & EN B1ab(iii)+2ab(iii); D & Yes & 2 \\
\hline ROSACEAE & Sorbus eystettensis & CR D & CR D & Yes & 1 \\
\hline ROSACEAE & Sorbus fischeri & EN D & EN D & Yes & 2 \\
\hline ROSACEAE & Sorbus franconica & VU D1 & VU D1 & Yes & 2 \\
\hline ROSACEAE & Sorbus futakiana & DD & DD & Yes & 0 \\
\hline ROSACEAE & Sorbus gauckleri & CR B1ab(iii)+2ab(iii); D & CR B1ab(iii)+2ab(iii); D & Yes & 1 \\
\hline ROSACEAE & Sorbus gayeriana & EN B1ab(iii)+2ab(iii); D & EN B1ab(iii)+2ab(iii); D & Yes & 3 \\
\hline ROSACEAE & Sorbus gemella & EN B1ab(iii)+2ab(iii); D & EN B1ab(iii)+2ab(iii); D & Yes & 1 \\
\hline
\end{tabular}




\begin{tabular}{|c|c|c|c|c|c|}
\hline Family & Species & $\begin{array}{l}\text { European Red List } \\
\text { Category and Criteria }\end{array}$ & $\begin{array}{c}\text { EU 28* Red List Category } \\
\text { and Criteria }\end{array}$ & Endemic & $\begin{array}{l}\text { Ex situ } \\
\text { collections }\end{array}$ \\
\hline ROSACEAE & Sorbus gerecseensis & EN B1ab(iii); D & EN B1ab(iii); D & Yes & 0 \\
\hline ROSACEAE & Sorbus graeca & LC & LC & No & 30 \\
\hline ROSACEAE & Sorbus greenii & CR D & CR D & Yes & 1 \\
\hline ROSACEAE & Sorbus harziana & CR D & CR D & Yes & 0 \\
\hline ROSACEAE & Sorbus hazslinszkyana & VU D1 & VU D1 & Yes & 3 \\
\hline ROSACEAE & Sorbus herbipolitana & CR D & CR D & Yes & 1 \\
\hline ROSACEAE & Sorbus herculis & $\mathrm{DD}$ & $\mathrm{DD}$ & Yes & 0 \\
\hline ROSACEAE & Sorbus herefordensis & EN D & EN D & Yes & 1 \\
\hline ROSACEAE & Sorbus hibernica & VU D1 & VU D1 & Yes & 12 \\
\hline ROSACEAE & Sorbus hoppeana & EN D & EN D & Yes & 1 \\
\hline ROSACEAE & Sorbus hornadensis & EN B1ab(iii)+2ab(iii); D & EN B1ab(iii)+2ab(iii); D & Yes & 1 \\
\hline ROSACEAE & Sorbus hungarica & $\mathrm{DD}$ & $\mathrm{DD}$ & Yes & 0 \\
\hline ROSACEAE & Sorbus hybrida & $\mathrm{LC}$ & $\mathrm{LC}$ & Yes & 57 \\
\hline ROSACEAE & Sorbus intermedia & $\mathrm{LC}$ & $\mathrm{LC}$ & Yes & 96 \\
\hline ROSACEAE & Sorbus javorkana & VU D1 & VU D1 & Yes & 1 \\
\hline ROSACEAE & Sorbus joannis & $\mathrm{DD}$ & $\mathrm{DD}$ & Yes & 0 \\
\hline ROSACEAE & Sorbus keszthelyensis & VU D1 & VU D1 & Yes & 0 \\
\hline ROSACEAE & Sorbus klasterskyana & EN D & EN D & Yes & 0 \\
\hline ROSACEAE & Sorbus kmetiana & CR D & CR D & Yes & 0 \\
\hline ROSACEAE & Sorbus lancastriensis & LC & LC & Yes & 17 \\
\hline ROSACEAE & Sorbus lancifolia & CR B1ab(iii,v)+2ab(iii,v) & NA & Yes & 8 \\
\hline ROSACEAE & Sorbus latifolia & VU B1ab(iii) & VU B1ab(iii) & Yes & 64 \\
\hline ROSACEAE & Sorbus latissima & DD & $\mathrm{DD}$ & Yes & 5 \\
\hline ROSACEAE & Sorbus legrei & EN D & EN D & Yes & 2 \\
\hline ROSACEAE & Sorbus leighensis & EN D & EN D & Yes & 1 \\
\hline ROSACEAE & Sorbus leptophylla & EN D & EN D & Yes & 12 \\
\hline ROSACEAE & Sorbus leyana & CR D & CR D & Yes & 10 \\
\hline ROSACEAE & Sorbus lonetalensis & $\begin{array}{c}\text { CR } \\
\text { B1ab(iii,v)+2ab(iii,v); D }\end{array}$ & $\begin{array}{c}\text { CR } \\
\text { B1ab(iii,v)+2ab(iii,v); D }\end{array}$ & Yes & 0 \\
\hline ROSACEAE & Sorbus magocsyana & EN D & EN D & Yes & 0 \\
\hline ROSACEAE & Sorbus margaretae & EN B1ab(iii); D & EN D & Yes & 3 \\
\hline ROSACEAE & Sorbus meierottii & CR D & CR D & Yes & 1 \\
\hline ROSACEAE & Sorbus meinichii & VU D1 & NA & Yes & 24 \\
\hline ROSACEAE & Sorbus mergenthaleriana & CR D & CR D & Yes & 2 \\
\hline ROSACEAE & Sorbus meyeri & VU D1 & VU D1 & Yes & 0 \\
\hline ROSACEAE & Sorbus milensis & CR B1ab(iii)+2ab(iii); D & CR B1ab(iii)+2ab(iii); D & Yes & 1 \\
\hline ROSACEAE & Sorbus minima & VU D1 & VU D1 & Yes & 31 \\
\hline ROSACEAE & Sorbus moravica & CR B1ab(iii)+2ab(iii) & CR B1ab(iii)+2ab(iii) & Yes & 0 \\
\hline ROSACEAE & Sorbus mongeotii & LC & LC & Yes & 55 \\
\hline ROSACEAE & Sorbus neglecta & EN B1ab(iii)+2ab(iii); D & NA & Yes & 2 \\
\hline ROSACEAE & Sorbus obtusifolia & $\mathrm{LC}$ & EN D & Yes & 4 \\
\hline ROSACEAE & Sorbus omissa & EN B1ab(iii)+2ab(iii); D & EN B1ab(iii)+2ab(iii); D & Yes & 1 \\
\hline ROSACEAE & Sorbus pannonica & VU D1 & VU D1 & Yes & 4 \\
\hline ROSACEAE & Sorbus parviloba & CR D & CR D & Yes & 4 \\
\hline ROSACEAE & Sorbus paxiana & DD & $\mathrm{DD}$ & Yes & 0 \\
\hline ROSACEAE & Sorbus pekarovae & CR B1ab(iii) & CR B1ab(iii) & Yes & 1 \\
\hline ROSACEAE & Sorbus pelsoensis & $\mathrm{DD}$ & $\mathrm{DD}$ & Yes & 0 \\
\hline
\end{tabular}




\begin{tabular}{|c|c|c|c|c|c|}
\hline Family & Species & $\begin{array}{l}\text { European Red List } \\
\text { Category and Criteria }\end{array}$ & $\begin{array}{c}\text { EU } 28^{*} \text { Red List Category } \\
\text { and Criteria }\end{array}$ & Endemic & $\begin{array}{l}\text { Ex situ } \\
\text { collections }\end{array}$ \\
\hline ROSACEAE & Sorbus perlonga & CR D & CR D & Yes & 2 \\
\hline ROSACEAE & Sorbus polgariana & CR B1ab(iii)+2ab(iii) & CR B1ab(iii)+2ab(iii) & Yes & 0 \\
\hline ROSACEAE & Sorbus pontis-satanae & CR B1ab(iii)+2ab(iii); D & CR B1ab(iii)+2ab(iii); D & Yes & 0 \\
\hline ROSACEAE & Sorbus porrigentiformis & VU D1 & VU D1 & Yes & 16 \\
\hline ROSACEAE & Sorbus portae-bohemicae & CR D & CR D & Yes & 1 \\
\hline ROSACEAE & Sorbus pseudobakonyensis & EN B1ab(iii)+2ab(iii) & EN B1ab(iii)+2ab(iii) & Yes & 5 \\
\hline ROSACEAE & Sorbus pseudofennica & CR B1ab(iii) & CR B1ab(iii)+2ab(iii) & Yes & 15 \\
\hline ROSACEAE & Sorbus pseudolatifolia & EN B1ab(iii)+2ab(iii); D & EN B1ab(iii)+2ab(iii); D & Yes & 3 \\
\hline ROSACEAE & Sorbus pseudomeinichii & $\begin{array}{c}\text { CR } \\
\text { B1ab(iii,iv,v)+2ab(iii,iv,v); D }\end{array}$ & $\begin{array}{c}\text { CR } \\
3(\mathrm{iii}, \mathrm{iv}, \mathrm{v})+2 \mathrm{ab}(\mathrm{iii}, \mathrm{iv}, \mathrm{v}) ; \mathrm{D}\end{array}$ & Yes & 2 \\
\hline ROSACEAE & Sorbus pseudosemiincisa & DD & DD & Yes & 2 \\
\hline ROSACEAE & Sorbus pseudothuringiaca & EN D & EN D & Yes & 1 \\
\hline ROSACEAE & Sorbus pseudovertesensis & VU B1ab(iii)+2ab(iii) & VU B1ab(iii)+2ab(iii) & Yes & 6 \\
\hline ROSACEAE & Sorbus puellarum & EN B1ab(iii)+2ab(iii); D & EN B1ab(iii)+2ab(iii); D & Yes & 1 \\
\hline ROSACEAE & Sorbus pulchra & CR D & CR D & Yes & 1 \\
\hline ROSACEAE & Sorbus pyricarpa & CR D & CR D & Yes & 0 \\
\hline ROSACEAE & Sorbus ratisbonensis & EN D & EN D & Yes & 1 \\
\hline ROSACEAE & Sorbus redliana & VU B1ab(iii)+2ab(iii) & VU B1ab(iii)+2ab(iii) & Yes & 4 \\
\hline ROSACEAE & Sorbus remensis & EN B1ab(iii) & EN B1ab(iii) & Yes & 2 \\
\hline ROSACEAE & Sorbus rhodanthera & CR B1ab(iii) & CR B1ab(iii) & Yes & 1 \\
\hline ROSACEAE & Sorbus richii & CR D & CR D & Yes & 1 \\
\hline ROSACEAE & Sorbus roopiana & CR D & NA & No & 5 \\
\hline ROSACEAE & Sorbus rupicola & LC & LC & Yes & 25 \\
\hline ROSACEAE & Sorbus rupicoloides & $\begin{array}{c}\text { CR } \\
\text { B1ab(iii,v)+2ab(iii,v); } \\
\text { C2a(i,ii); D }\end{array}$ & $\begin{array}{c}\text { CR } \\
\text { B1ab(iii,v)+2ab(iii,v); } \\
\text { C2a(i,ii); D }\end{array}$ & Yes & 2 \\
\hline ROSACEAE & Sorbus saxicola & CR D & CR D & Yes & 2 \\
\hline ROSACEAE & Sorbus scannelliana & CR D & CR D & Yes & 0 \\
\hline ROSACEAE & Sorbus scepusiensis & CR D & CR D & Yes & 1 \\
\hline ROSACEAE & Sorbus schnizleiniana & CR B1ab(iii)+2ab(iii); D & CR B1ab(iii)+2ab(iii); D & Yes & 1 \\
\hline ROSACEAE & Sorbus schuwerkiorum & CR D & CR D & Yes & 2 \\
\hline ROSACEAE & Sorbus schwarziana & CR B1ab(iii,v); D & CR B1ab(iii); D & Yes & 1 \\
\hline ROSACEAE & Sorbus sellii & $\mathrm{DD}$ & DD & Yes & 2 \\
\hline ROSACEAE & Sorbus semiincisa & VU B1ab(iii) & VU B1ab(iii) & Yes & 8 \\
\hline ROSACEAE & Sorbus semipinnata & $\mathrm{DD}$ & $\mathrm{DD}$ & Yes & 0 \\
\hline ROSACEAE & Sorbus seyboldiana & CR D & CR D & Yes & 0 \\
\hline ROSACEAE & Sorbus simonkaiana & VU B1ab(iii)+2ab(iii) & VU B1ab(iii)+2ab(iii) & Yes & 11 \\
\hline ROSACEAE & Sorbus slovenica & EN D & EN D & Yes & 0 \\
\hline ROSACEAE & Sorbus sognensis & EN D & NA & Yes & 2 \\
\hline ROSACEAE & Sorbus spectans & CR D & CR D & Yes & 1 \\
\hline ROSACEAE & Sorbus stankovii & NT & NA & No & 6 \\
\hline ROSACEAE & Sorbus stenophylla & EN D & EN D & Yes & 2 \\
\hline ROSACEAE & Sorbus stirtoniana & CR D & CR D & Yes & 2 \\
\hline ROSACEAE & Sorbus subarranensis & EN D & NA & Yes & 1 \\
\hline ROSACEAE & Sorbus subcuneata & EN D & EN D & Yes & 10 \\
\hline ROSACEAE & Sorbus subdanubialis & VU D1 & VU D1 & Yes & 0 \\
\hline ROSACEAE & Sorbus subpinnata & EN D & NA & Yes & 3 \\
\hline
\end{tabular}




\begin{tabular}{|c|c|c|c|c|c|}
\hline Family & Species & $\begin{array}{c}\text { European Red List } \\
\text { Category and Criteria }\end{array}$ & $\begin{array}{l}\text { EU 28* Red List Category } \\
\text { and Criteria }\end{array}$ & Endemic & $\begin{array}{c}\text { Ex situ } \\
\text { collections }\end{array}$ \\
\hline ROSACEAE & Sorbus subsimilis & VU D1 & $\mathrm{NA}$ & Yes & 12 \\
\hline ROSACEAE & Sorbus taurica & $\mathrm{LC}$ & NA & No & 4 \\
\hline ROSACEAE & Sorbus tauricola & EN B1ab(v) & NA & Yes & 2 \\
\hline ROSACEAE & Sorbus teodori & DD & $\mathrm{DD}^{*}$ & Yes & 1 \\
\hline ROSACEAE & Sorbus thaiszii & EN D & EN D & Yes & 3 \\
\hline ROSACEAE & Sorbus thayensis & CR D & CR D & Yes & 0 \\
\hline ROSACEAE & Sorbus tobani & CR D & CR D & Yes & 0 \\
\hline ROSACEAE & Sorbus torminalis & LC & LC & No & 114 \\
\hline ROSACEAE & Sorbus udvardyana & EN B1ab(iii)+2ab(iii) & EN B1ab(iii)+2ab(iii) & Yes & 0 \\
\hline ROSACEAE & Sorbus ujhelyii & CR D & CR D & Yes & 0 \\
\hline ROSACEAE & Sorbus ulmifolia & $\mathrm{DD}$ & $\mathrm{DD}$ & Yes & 0 \\
\hline ROSACEAE & Sorbus umbellata & LC & LC & No & 20 \\
\hline ROSACEAE & Sorbus vajdae & $\mathrm{DD}$ & $\mathrm{DD}$ & Yes & 1 \\
\hline ROSACEAE & Sorbus vallerubusensis & CR D & CR D & Yes & 0 \\
\hline ROSACEAE & Sorbus velebitica & $\mathrm{DD}$ & $\mathrm{DD}$ & Yes & 0 \\
\hline ROSACEAE & Sorbus vertesensis & VU B1ab(iii)+2ab(iii) & VU B1ab(iii)+2ab(iii) & Yes & 6 \\
\hline ROSACEAE & Sorbus veszpremensis & VU D1+2 & VU D1 & Yes & 0 \\
\hline ROSACEAE & Sorbus vexans & CR D & CR D & Yes & 11 \\
\hline ROSACEAE & Sorbus whiteana & CR D & CR D & Yes & 3 \\
\hline ROSACEAE & Sorbus wilmottiana & EN D & EN D & Yes & 12 \\
\hline ROSACEAE & Sorbus zertovae & CR D & CR D & Yes & 0 \\
\hline ROSACEAE & Sorbus zolyomii & $\mathrm{DD}$ & $\mathrm{DD}$ & Yes & 3 \\
\hline RUBIACEAE & Plocama pendula & LC & LC & Yes & 9 \\
\hline SALICACEAE & Populus alba & $\mathrm{LC}$ & LC* & No & 113 \\
\hline SALICACEAE & Populus nigra & $\mathrm{DD}$ & $\mathrm{DD}$ & No & 78 \\
\hline SALICACEAE & Populus tremula & LC & LC & No & 81 \\
\hline SALICACEAE & Salix acutifolia & LC & LC & No & 37 \\
\hline SALICACEAE & Salix alba & LC & LC* & No & 93 \\
\hline SALICACEAE & Salix appendiculata & LC & LC & Yes & 14 \\
\hline SALICACEAE & Salix atrocinerea & $\mathrm{LC}$ & LC & No & 18 \\
\hline SALICACEAE & Salix bebbiana & LC & LC & No & 21 \\
\hline SALICACEAE & Salix canariensis & NT & NT & Yes & 4 \\
\hline SALICACEAE & Salix caprea & LC & LC & No & 123 \\
\hline SALICACEAE & Salix cinerea & LC & LC & No & 62 \\
\hline SALICACEAE & Salix daphnoides & LC & LC $^{*}$ & Yes & 51 \\
\hline SALICACEAE & Salix eleagnos & LC & $\mathrm{LC}$ & No & 14 \\
\hline SALICACEAE & Salix gussonei & $\mathrm{LC}$ & LC & Yes & 1 \\
\hline SALICACEAE & Salix ionica & NT & NT & Yes & 0 \\
\hline SALICACEAE & Salix myrsinifolia & LC & LC & No & 47 \\
\hline SALICACEAE & Salix oropotamica & LC & LC & Yes & 0 \\
\hline SALICACEAE & Salix pedicellata & LC & LC & No & 4 \\
\hline SALICACEAE & Salix pentandra & LC & LC & No & 70 \\
\hline SALICACEAE & Salix phylicifolia & LC & LC & No & 26 \\
\hline SALICACEAE & Salix purpurea & LC & LC $^{*}$ & No & 78 \\
\hline SALICACEAE & Salix pyrolifolia & LC & CR C2a(i);D & No & 6 \\
\hline SALICACEAE & Salix salviifolia & LC & LC & Yes & 3 \\
\hline
\end{tabular}




\begin{tabular}{|c|c|c|c|c|c|}
\hline Family & Species & $\begin{array}{l}\text { European Red List } \\
\text { Category and Criteria }\end{array}$ & $\begin{array}{l}\text { EU 28* Red List Category } \\
\text { and Criteria }\end{array}$ & Endemic & $\begin{array}{c}\text { Ex situ } \\
\text { collections }\end{array}$ \\
\hline SALICACEAE & Salix triandra & LC & LC & No & 35 \\
\hline SALICACEAE & Salix viminalis & LC & LC & No & 73 \\
\hline SANTALACEAE & Osyris lanceolata & LC & LC & No & 6 \\
\hline SAPINDACEAE & Acer campestre & LC & LC & No & 208 \\
\hline SAPINDACEAE & Acer granatense & LC & LC & No & 11 \\
\hline SAPINDACEAE & Acer heldreichii & LC & LC & Yes & 38 \\
\hline SAPINDACEAE & Acer hyrcanum & LC & LC & No & 35 \\
\hline SAPINDACEAE & Acer lobelii & LC & LC & Yes & 11 \\
\hline SAPINDACEAE & Acer monspessulanum & LC & LC & No & 127 \\
\hline SAPINDACEAE & Acer obtusifolium & LC & LC & No & 24 \\
\hline SAPINDACEAE & Acer opalus & LC & LC & No & 65 \\
\hline SAPINDACEAE & Acer platanoides & LC & LC & No & 184 \\
\hline SAPINDACEAE & Acer pseudoplatanus & LC & LC & No & 168 \\
\hline SAPINDACEAE & Acer sempervirens & LC & LC & No & 44 \\
\hline SAPINDACEAE & Acer tataricum & LC & LC & No & 127 \\
\hline SAPINDACEAE & Aesculus hippocastanum & VU C2a(i) & VU C2a(i) & Yes & 185 \\
\hline SAPOTACEAE & Sideroxylon canariense & EN D & EN D & Yes & 1 \\
\hline SAPOTACEAE & Sideroxylon mirmulans & EN B1ab(iii)+2ab(iii) & EN B1ab(iii)+2ab(iii) & Yes & 2 \\
\hline STAPHYLEACEAE & Staphylea pinnata & LC & LC & No & 119 \\
\hline STYRACACEAE & Styrax officinalis & $\mathrm{LC}$ & LC & No & 43 \\
\hline TAMARICACEAE & Tamarix africana & LC & LC & No & 21 \\
\hline TAMARICACEAE & Tamarix boveana & VU B2ab(iii,iv,v) & VU B2ab(iii,iv) & No & 2 \\
\hline TAMARICACEAE & Tamarix canariensis & LC & LC & Yes & 7 \\
\hline TAMARICACEAE & Tamarix dalmatica & LC & LC & No & 1 \\
\hline TAMARICACEAE & Tamarix gallica & $\mathrm{LC}$ & LC & No & 23 \\
\hline TAMARICACEAE & Tamarix hampeana & $\mathrm{LC}$ & LC & No & 0 \\
\hline TAMARICACEAE & Tamarix hispida & LC & $\mathrm{NA}$ & No & 3 \\
\hline TAMARICACEAE & Tamarix minoa & $\mathrm{DD}$ & $\mathrm{DD}$ & Yes & 0 \\
\hline TAMARICACEAE & Tamarix nilotica & $\mathrm{LC}$ & $\mathrm{LC}$ & No & 0 \\
\hline TAMARICACEAE & Tamarix parviflora & LC & LC & No & 43 \\
\hline TAMARICACEAE & Tamarix ramosissima & LC & LC & No & 35 \\
\hline TAMARICACEAE & Tamarix smyrnensis & LC & LC & No & 3 \\
\hline TAMARICACEAE & Tamarix tetragyna & $\mathrm{LC}$ & LC & No & 1 \\
\hline TAMARICACEAE & Tamarix tetrandra & $\mathrm{LC}$ & LC & No & 30 \\
\hline TAXACEAE & Taxus baccata & $\mathrm{LC}$ & LC & No & 212 \\
\hline ULMACEAE & Celtis australis & $\mathrm{LC}$ & LC & No & 107 \\
\hline ULMACEAE & Celtis planchoniana & $\mathrm{DD}$ & $\mathrm{DD}$ & No & 6 \\
\hline ULMACEAE & Celtis tournefortii & LC & LC & No & 42 \\
\hline ULMACEAE & Ulmus glabra & VU A2be+3be+4be & VU & No & 91 \\
\hline ULMACEAE & Ulmus laevis & $\mathrm{DD}$ & $\mathrm{DD}$ & No & 71 \\
\hline ULMACEAE & Ulmus minor & $\mathrm{DD}$ & $\mathrm{DD}$ & No & 69 \\
\hline ULMACEAE & Zelkova abelicea & EN B1ab(iii)+2ab(iii) & EN B1ab(iii)+2ab(iii)* & Yes & 23 \\
\hline ULMACEAE & Zelkova sicula & CR B1ab(iii)+2ab(iii) & CR B1ab(iii)+2ab(iii) & Yes & 4 \\
\hline URTICACEAE & Gesnouinia arborea & EN B2ab(iii); D & EN B2ab(iii) & Yes & 13 \\
\hline VERBENACEAE & Vitex agnus-castus & $\mathrm{DD}$ & $\mathrm{DD}^{*}$ & No & 182 \\
\hline
\end{tabular}




\section{Annex 2}

Summary of the IUCN Red List Category and Criteria.

A. Population size reduction. Population reduction (measured over the longer of 10 years or 3 generations) based on any of A1 to A4

A1

A2, A3 \& A4

A1 Population reduction observed, estimated, inferred, or suspected in the past where the causes of the reduction are clearly reversible AND understood AND have ceased.

A2 Population reduction observed, estimated, inferred, or suspected in the past where the causes of reduction may not have ceased OR may not be understood OR may not be reversible.

A3 Population reduction projected, inferred or suspected to be met in the future (up to a maximum of 100 years) [(a) cannot be used for A3].

A4 An observed, estimated, inferred, projected or suspected population reduction where the time period must include both the past and the future (up to a max. of 100 years in future), and where the causes of reduction may not have ceased OR may not be understood OR may not be reversible.

\begin{tabular}{|c|c|}
\hline Endangered & Vulnerable \\
\hline$\geq 70 \%$ & $\geq 50 \%$ \\
$\geq 50 \%$ & $\geq 30 \%$ \\
\hline
\end{tabular}

(a) direct observation [except A3]

(b) an index of abundance appropriate to the taxon

(c) a decline in area of occupancy (AOO), extent of occurrence (EOO) and/or habitat quality

based on any of the following:

(d) actual or potential levels of exploitation

(e) effects of introduced taxa, hybridization, pathogens, pollutants, competitors or parasites.

B. Geographic range in the form of either B1 (extent of occurrence) AND/OR B2 (area of occupancy)

B1. Extent of occurrence (EOO)

B2. Area of occupancy (AOO)

Critically Endangered
\[ 100 \mathrm{~km}^{2} \]
$<10 \mathrm{~km}^{2}$

Endangered

$<5,000 \mathrm{~km}^{2}$

$<500 \mathrm{~km}^{2}$
Vulnerable

$<20,000 \mathrm{~km}^{2}$

$<2,000 \mathrm{~km}^{2}$

AND at least 2 of the following 3 conditions:

(a) Severely fragmented OR Number of locations

$=1$

$\leq 5$

$\leq 10$

(b) Continuing decline observed, estimated, inferred or projected in any of: (i) extent of occurrence; (ii) area of occupancy; (iii) area, extent and/or quality of habitat; (iv) number of locations or subpopulations; (v) number of mature individuals

(c) Extreme fluctuations in any of: (i) extent of occurrence; (ii) area of occupancy; (iii) number of locations or subpopulations; (iv) number of mature individuals

\section{Small population size and decline}

\section{Number of mature individuals}

Critically Endangered
\[ <250 \]

Endangered

\section{Vulnerable}

$<10,000$

\section{AND at least one of $\mathrm{C} 1$ or $\mathrm{C2}$}

C1. An observed, estimated or projected continuing decline of at least (up to a max. of 100 years in future):

C2. An observed, estimated, projected or inferred continuing decline AND at least 1 of the following 3 conditions:

(a) (i) Number of mature individuals in each subpopulation (ii) \% of mature individuals in one subpopulation =

(b) Extreme fluctuations in the number of mature individuals

\section{$25 \%$ in 3 years or}

1 generation

(whichever is longer)
$20 \%$ in 5 years or

2 generations

(whichever is longer)
$10 \%$ in 10 years or

3 generations

(whichever is longer)

D. Very small or restricted population

D. Number of mature individuals

D2. Only applies to the VU category

Restricted area of occupancy or number of locations with

a plausible future threat that could drive the taxon to $C R$ or EX in a very short time.

\begin{tabular}{|c|c|c}
\hline$\leq 50$ & $\leq 250$ & $\leq 1,000$ \\
\hline $90-100 \%$ & $95-100 \%$ & $100 \%$ \\
\hline
\end{tabular}

Indicating the probability of extinction in the wild to be:
E. Quantitative Analysis

\begin{tabular}{|c|c|c|}
\hline Critically Endangered & Endangered & Vulnerable \\
\hline$<50$ & $<250$ & D1. $\quad<1,000$
\end{tabular}

\begin{tabular}{|c|c|c|}
\hline Critically Endangered & Endangered & Vulnerable \\
\hline $\begin{array}{c}\geq 50 \% \text { in } 10 \text { years or } 3 \\
\text { generations, whichever } \\
\text { is longer (100 years } \\
\text { max.) }\end{array}$ & $\begin{array}{c}\text { generations, whichever } \\
\text { is longer (100 years } \\
\text { max.) }\end{array}$ & $\geq 10 \%$ in 100 years \\
\hline
\end{tabular}
max.)

1 Use of this summary sheet requires full understanding of the IUCN Red List Categories and Criteria and Guidelines for Using the IUCN Red List Categories and Criteria. Please refer to both documents for explanations of terms and concepts used here. 


\title{
Annex 3
}

Example of species summary and distribution map.

The Red List assessment below of Dracaena tamaranae Marrero Rodr., R.S.Almeira \& M.Gonzáles-Martin. provides an example of the information that has been compiled for all the European tree species. You can search for and download all the assessments from the European Red List website and data portal at http://ec.europa.eu/environment/nature/ conservation/species/redlist/ and https://www.iucnredlist.org/regions/europe.

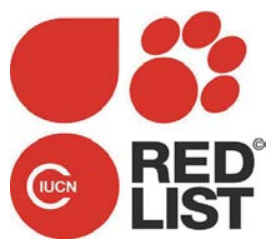

The IUCN Red List of Threatened Species ${ }^{T M}$ ISSN 2307-8235 (online)

IUCN 2008: T79726923A79726929

Scope: Global

Language: English

\section{Dracaena tamaranae, Drago de Gran Canaria}

\begin{abstract}
Assessment by: Marrero Rodríguez, Á, Almeida Pérez, R.S., Beech, E. \& Rivers,
\end{abstract} M.C.

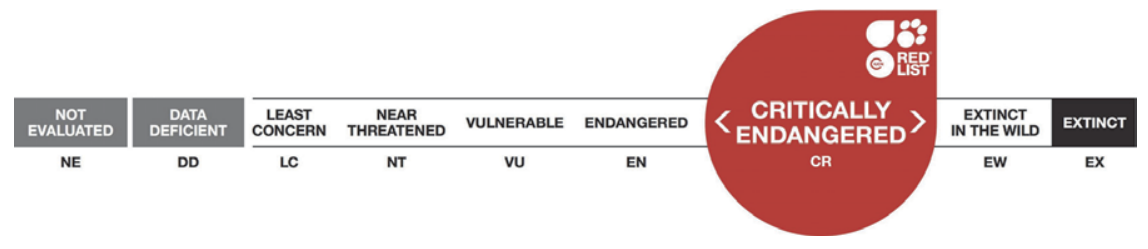

View on www.iucnredlist.org

Citation: Marrero Rodríguez, Á, Almeida Pérez, R.S., Beech, E. \& Rivers, M.C. 2017. Dracaena tamaranae. The IUCN Red List of Threatened Species 2017: e.T79726923A79726929.

http://dx.doi.org/10.2305/IUCN.UK.2017-3.RLTS.T79726923A79726929.en

Copyright: @ 2017 International Union for Conservation of Nature and Natural Resources

Reproduction of this publication for educational or other non-commercial purposes is authorized without prior written permission from the copyright holder provided the source is fully acknowledged.

Reproduction of this publication for resale, reposting or other commercial purposes is prohibited without prior written permission from the copyright holder. For further details see Terms of Use.

The IUCN Red List of Threatened Species ${ }^{T M}$ is produced and managed by the IUCN Global Species Programme, the IUCN Species Survival Commission (SSC) and The IUCN Red List Partnership. The IUCN Red List Partners are: Arizona State University; BirdLife International; Botanic Gardens Conservation International; Conservation International; NatureServe; Roval Botanic Gardens, Kew; Sapienza University of Rome; Texas A\&M University; and Zoological Society of London.

If you see any errors or have any questions or suggestions on what is shown in this document, please provide us with feedback so that we can correct or extend the information provided. 


\section{Taxonomy}

\begin{tabular}{|c|c|c|c|c|}
\hline Kingdom & Phylum & Class & Order & Family \\
\hline Plantae & Tracheophyta & Liliopsida & Liliales & Dracaenaceae \\
\hline
\end{tabular}

Taxon Name: Dracaena tamaranae Marrero Rodr., R.S.Almeira \& M.Gonzáles-Martin

\section{Common Name(s):}

- Spanish: Drago de Gran Canaria

\section{Taxonomic Source(s):}

The Plant List. 2013. The Plant List Version 1.1. Available at: http://www.theplantlist.org/. (Accessed: July 2016).

\section{Assessment Information}

Red List Category \& Criteria: Critically Endangered C2a(i); D ver 3.1

Year Published:

2017

Date Assessed:

November 17, 2015

\section{Justification:}

This is a small tree found only on Gran Canaria in the Canary Islands. It qualifies for Critically Endangered under Criterion D as there are only 12 known mature individuals. It also qualifies under Criterion C2a(i) as there has been a continuing decline with a small number of individuals in each subpopulation. Although many of these trees are found in protected areas, there is continuing threat from introduced herbivores (rabbits), grazing, and stochastic events. As recruitment is low, intervention may be necessary to prevent this species from extinction.

\section{Geographic Range}

\section{Range Description:}

This tree is endemic to the Canary Islands, where it is restricted to the southwestern sector of Gran Canaria (Jardín Botánico Canario "Viera y Clavijo" 2007, Díaz-Bertrana Sánchez 2015). The species is found between 342 and 1,270 m above sea level (Almeida Pérez 2003, Bañares et al. 2004). This species has an extent of occurrence of $318 \mathrm{~km}^{2}$ and an area of occupancy of $94 \mathrm{~km}^{2}$.

\section{Country Occurrence:}

Native: Spain (Canary Is.) 


\section{Distribution Map}

Dracaena tamaranae

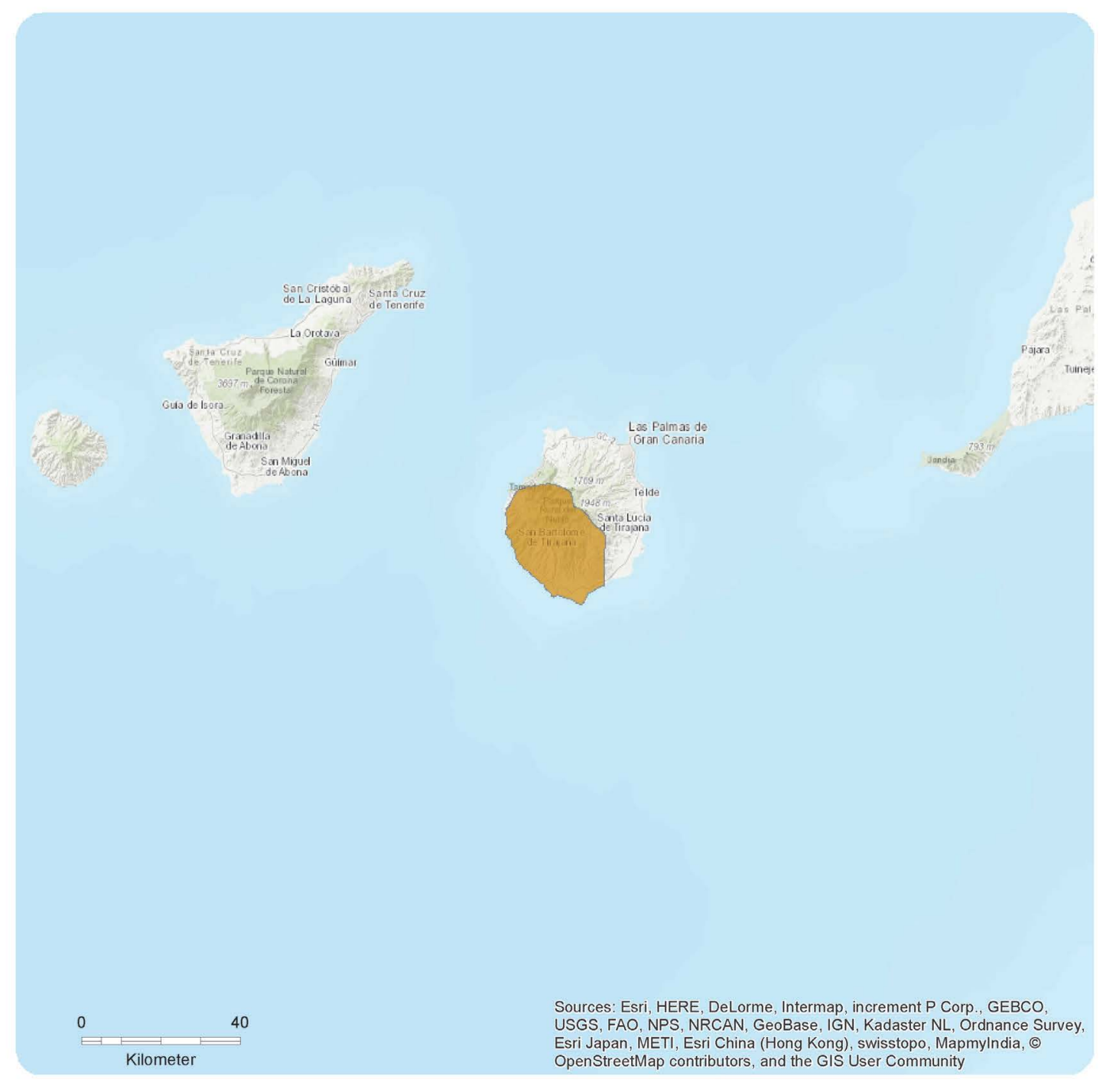

Range

Extant (resident)

Compiled by:

BGCI

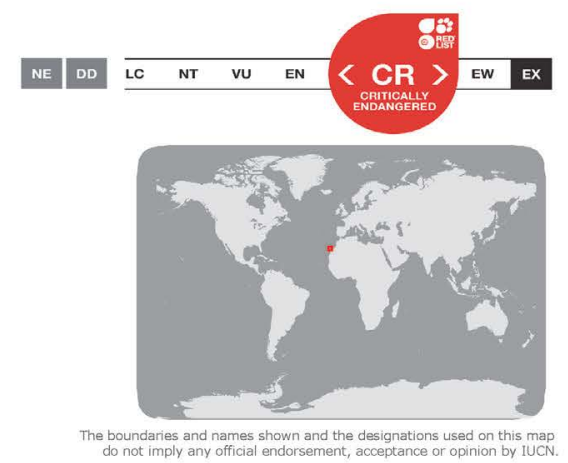




\section{Population}

This species is extremely rare and found in a small number of localities (Jardín Botánico Canario "Viera y Clavijo" 2007). At present (Díaz-Bertrana Sánchez 2015) the species is primarily found in two separate clusters: one in Arguineguín-Tauro, and the other in Fataga-Vicentillos, as well as some isolated individuals outside these enclaves. Recent survey (Díaz-Bertrana Sánchez 2015) found 74 individuals, of which 61 are juveniles and 12 are considered to be mature. In the last 25 years, ten individuals appear to have been lost, the majority adults. The youngest individual is estimated to be more than 80 years old, with no flowering individuals (however flowering is irregular) or seedlings were found in the recent survey (Díaz-Bertrana Sánchez 2015). The species is considered to be severely fragmented.

Current Population Trend: Decreasing

\section{Habitat and Ecology (see Appendix for additional information)}

This species is found on rock on steep cliffs and in rocky areas at the base of cliffs (Jardín Botánico Canario "Viera y Clavijo" 2007) and in Maytenus-Juniperus canariensis thermophillic forest (Bañares et al. 2004). It fruits irregularly, it can be ten years or more in between fruit. The fruits can remain on the ground until the following year.

Systems: Terrestrial

\section{Use and Trade}

There is no trade or use of this species.

\section{Threats (see Appendix for additional information)}

The threats to this species include habitat fragmentation, consumption of seedlings by herbivores (e.g., rabbits), and grazing. The species is also threatened by stochastic environmental events such as landslides, droughts and torrential rain (Bañares et al. 2004). Prolonged drought is though to suppress seed germination when the plants do flower, as well as suppressing vegetation and causing branching of mature individuals (Díaz-Bertrana Sánchez 2015).

\section{Conservation Actions (see Appendix for additional information)}

This tree's habitat is included in the Habitat Directive (Council of Europe 1992). It is found within several protected areas including the Monumento Natural de Tauro (Bañares et al. 2004). It is recommended that grazing is controlled and demographic monitoring occurs. Seed banking and reintroduction programmes should be considered (Bañares et al. 2004, Díaz-Bertrana Sánchez 2015). Some areas have been protected from grazing by fencing. Dracaena tamaranae is reported as held in four ex situ collections (BGCl 2015).

\section{Credits}

Assessor(s): $\quad$ Marrero Rodríguez, Á, Almeida Pérez, R.S., Beech, E. \& Rivers, M.C.

Reviewer(s): $\quad$ Reyes Betancort, J.A., Scholz, S., del Arco Aguilar, M. \& Allen, D.J. 


\section{Bibliography}

Almeida Pérez, R.S. 2003. Censo, distribución, habitat y estado de conservación de Dracaena tamaranae A.Marrero, R.S. Almeida \& M.González Martín. Gran Canaria, Islas Canarias. Botánica Macaronésica 24: 39-56.

Bañares, Á., Blanca, G., Güemes, J., Moreno, J.C. and Ortiz, S. (eds). 2004. Atlas y Libro Rojo de la Flora Vascular Amenazada de España. Dirección General de Conservación de la Naturaleza, Madrid.

Bañares, Á., Blanca, G., Güemes, J., Moreno, J.C., and Ortiz, S. (eds). 2011. Atlas y Libro Rojo de la Flora Vascular Amenazada de España. Adenda 2010. pp. 170. Dirección General de Medio Natural y Política Forestal (Ministerio de Medio Ambiente, y Medio Rural y Marino)-Sociedad Española de Biología de la Conservación de Plantas, Madrid.

BGCI. 2017. PlantSearch. Available at: www.bgci.org/plant search.php.

Council of Europe. 1992. Council Directive 92/43/EEC.

Díaz-Bertrana Sánchez, M. 2015. Seguimiento de Poblaciones de Especies Amenazadas (2015): Dracaena tamaranae Marrero Rodr., R.S. Almeida \& M. González-Martín. Gobierno de Canarias.

IUCN. 2017. The IUCN Red List of Threatened Species. Version 2017-3. Available at: www.iucnredlist.org. (Accessed: 7 December 2017).

Jardín Botánico Canario "Viera y Clavijo" (ed.). 2007. Flora de las Islas Canarias en peligro crítico : top 100. pp. 128. Las Palmas de Gran Canaria.

\section{Citation}

Marrero Rodríguez, Á, Almeida Pérez, R.S., Beech, E. \& Rivers, M.C. 2017. Dracaena tamaranae. The IUCN Red List of Threatened Species 2017: e.T79726923A79726929.

http://dx.doi.org/10.2305/IUCN.UK.2017-3.RLTS.T79726923A79726929.en

\section{Disclaimer}

To make use of this information, please check the Terms of Use.

\section{External Resources}

For Images and External Links to Additional Information, please see the Red List website. 


\section{Appendix}

\section{Habitats}

(http://www.iucnredlist.org/technical-documents/classification-schemes)

\begin{tabular}{|c|c|c|c|}
\hline Habitat & Season & Suitability & $\begin{array}{l}\text { Major } \\
\text { Importance? }\end{array}$ \\
\hline 1. Forest $->1.4$. Forest - Temperate & Resident & Suitable & Yes \\
\hline 0. Root $>$ 6. Rocky areas (eg. inland cliffs, mountain peaks) & Resident & Suitable & Yes \\
\hline
\end{tabular}

\section{Threats}

(http://www.iucnredlist.org/technical-documents/classification-schemes)

\begin{tabular}{|c|c|c|c|c|}
\hline Threat & Timing & Scope & Severity & Impact Score \\
\hline \multirow[t]{2}{*}{ 10. Geological events -> 10.3. Avalanches/landslides } & Ongoing & Unknown & Unknown & Unknown \\
\hline & Stresses: & \multicolumn{3}{|c|}{$\begin{array}{l}\text { 1. Ecosystem stresses }->1.2 \text {. Ecosystem degradation } \\
\text { 2. Species Stresses }->2.1 \text {. Species mortality } \\
\text { 2. Species Stresses }->2.2 \text {. Species disturbance }\end{array}$} \\
\hline \multirow[t]{2}{*}{$\begin{array}{l}\text { 11. Climate change \& severe weather -> 11.2. } \\
\text { Droughts }\end{array}$} & Ongoing & Whole (>90\%) & $\begin{array}{l}\text { Slow, significant } \\
\text { declines }\end{array}$ & $\begin{array}{l}\text { Medium } \\
\text { impact: } 7\end{array}$ \\
\hline & Stresses: & \multicolumn{3}{|c|}{$\begin{array}{l}\text { 2. Species Stresses }->2.1 \text {. Species mortality } \\
\text { 2. Species Stresses }->2.3 \text {. Indirect species effects }-> \\
\text { 2.3.7. Reduced reproductive success }\end{array}$} \\
\hline \multirow{2}{*}{$\begin{array}{l}\text { 11. Climate change \& severe weather }->11.4 \text {. Storms } \\
\text { \& flooding }\end{array}$} & Ongoing & Whole (>90\%) & Unknown & Unknown \\
\hline & Stresses: & \multicolumn{3}{|c|}{$\begin{array}{l}\text { 2. Species Stresses } \rightarrow>2.1 \text {. Species mortality } \\
\text { 2. Species Stresses } \rightarrow 2.2 \text {. Species disturbance }\end{array}$} \\
\hline \multirow[t]{2}{*}{$\begin{array}{l}\text { 2. Agriculture \& aquaculture }->2.3 \text {. Livestock farming } \\
\& \text { ranching }->2.3 .2 \text {. Small-holder grazing, ranching or } \\
\text { farming }\end{array}$} & Ongoing & Unknown & Unknown & Unknown \\
\hline & Stresses: & \multicolumn{3}{|c|}{$\begin{array}{l}\text { 1. Ecosystem stresses }->1.2 \text {. Ecosystem degradation } \\
\text { 2. Species Stresses }->2.2 \text {. Species disturbance }\end{array}$} \\
\hline
\end{tabular}

\section{Conservation Actions in Place}

(http://www.iucnredlist.org/technical-documents/classification-schemes)

\begin{tabular}{|l|}
\hline Conservation Actions in Place \\
\hline In-Place Land/Water Protection and Management \\
\hline Occur in at least one PA: Yes \\
\hline In-Place Species Management \\
\hline Subject to ex-situ conservation: Yes \\
\hline
\end{tabular}

\section{Conservation Actions Needed}


(http://www.iucnredlist.org/technical-documents/classification-schemes)

\section{Conservation Actions Needed}

2. Land/water management -> 2.2. Invasive/problematic species control

3. Species management $->$ 3.3. Species re-introduction $->$ 3.3.1. Reintroduction

3. Species management -> 3.4. Ex-situ conservation -> 3.4.1. Captive breeding/artificial propagation

3. Species management -> 3.4. Ex-situ conservation -> 3.4.2. Genome resource bank

\section{Research Needed}

(http://www.iucnredlist.org/technical-documents/classification-schemes)

\section{Research Needed}

1. Research -> 1.2. Population size, distribution \& trends

1. Research $->1.5$. Threats

2. Conservation Planning -> 2.1. Species Action/Recovery Plan

3. Monitoring -> 3.1. Population trends

3. Monitoring $->$ 3.4. Habitat trends

\section{Additional Data Fields}

\section{Distribution}

Estimated area of occupancy (AOO) $\left(\mathrm{km}^{2}\right): 96$

Continuing decline in area of occupancy (AOO): Yes

Estimated extent of occurrence (EOO) $\left(\mathrm{km}^{2}\right): 318$

Continuing decline in extent of occurrence (EOO): Yes

Lower elevation limit $(m): 342$

Upper elevation limit (m): 1270

\section{Population}

Number of mature individuals: 12

Continuing decline of mature individuals: Yes

Extreme fluctuations: No

Population severely fragmented: Yes

Continuing decline in subpopulations: No

Extreme fluctuations in subpopulations: No

All individuals in one subpopulation: No

\section{Habitats and Ecology}

Continuing decline in area, extent and/or quality of habitat: Yes 


\section{The IUCN Red List Partnership}

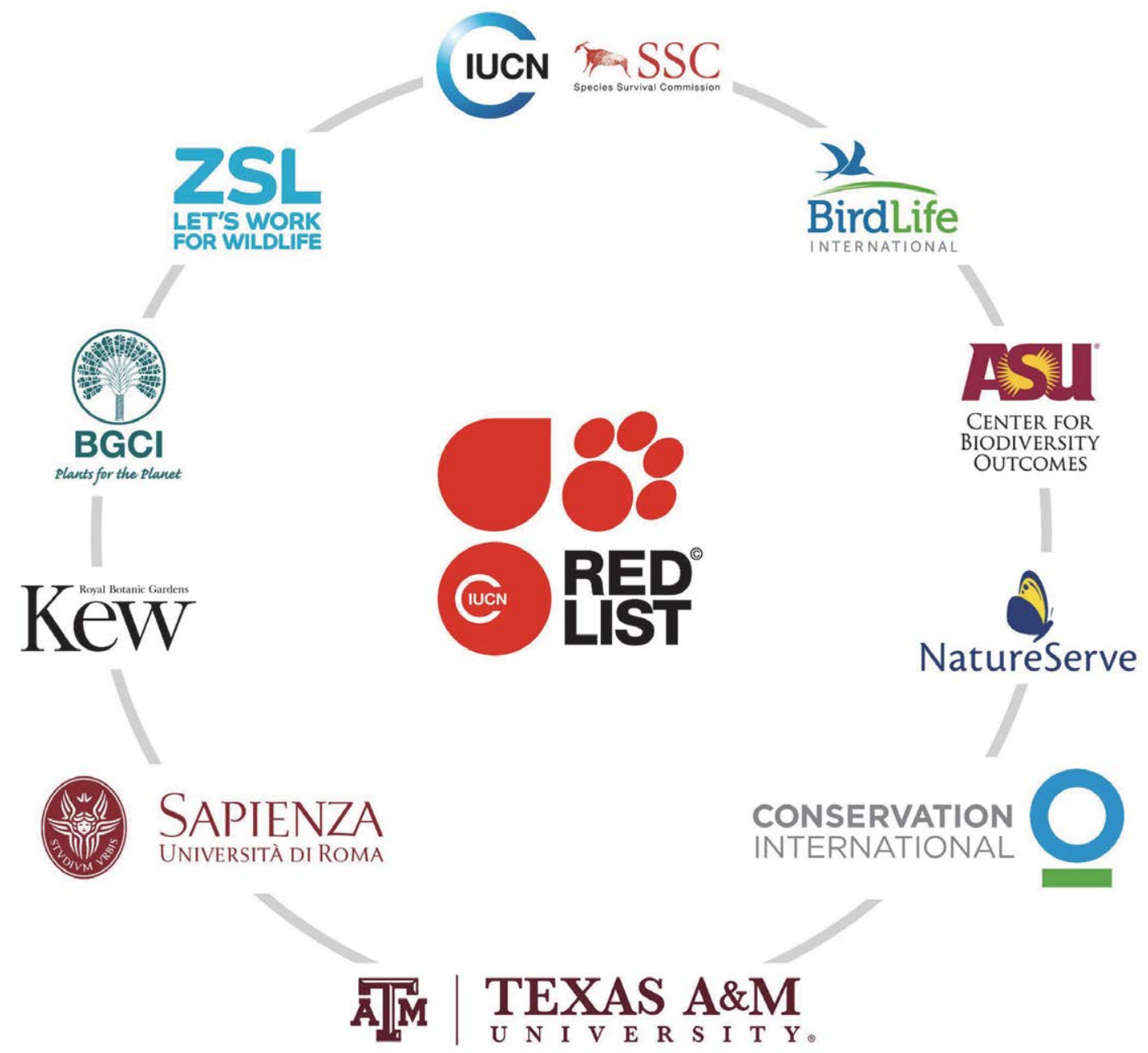

The IUCN Red List of Threatened Species ${ }^{T M}$ is produced and managed by the IUCN Global Species Programme, the IUCN Species Survival Commission (SSC) and The IUCN Red List Partnership.

The IUCN Red List Partners are: Arizona State University; BirdLife International; Botanic Gardens Conservation International; Conservation International; NatureServe; Roval Botanic Gardens, Kew; Sapienza University of Rome; Texas A\&M University; and Zoological Society of London. 



\section{IUCN Red List of Threatened Species $^{\mathrm{TM}}$ - European Regional Assessment Reports}

- The Status and Distribution of European Mammals. Temple and Terry (compilers), 2007. https://portals.iucn.org/library/node/9047

- European Red List of Reptiles. Cox and Temple (compilers), 2009. https://doi.org/10.2779/74504

- European Red List of Amphibians. Temple and Cox (compilers), 2009. https://doi.org/10.2779/73661

- European Red List of Dragonflies. Kalkman et al. (compilers), 2010. https://doi.org/10.2779/84650

- European Red List of Saproxylic Beetles. Nieto and Alexander (compilers), 2010. https://doi.org/10.2779/84561

- European Red List of Butterflies. van Swaay et al. (compilers), 2010. https://doi.org/10.2779/83897

- European Red List of Non-marine Molluscs. Cuttelod et al., 2011. https://doi.org/10.2779/84538

- European Red List of Freshwater Fishes. Freyhof and Brooks, 2011. https://doi.org/10.2779/85903

- European Red List of Vascular Plants. Bilz et al., 2011. https://doi.org/10.2779/8515

- European Red List of Medicinal Plants. Allen et al., 2014. https://doi.org/10.2779/907382

- European Red List of Bees. Nieto et al., 2014. https://doi.org/10.2779/51181

- European Red List of Birds. BirdLife International, 2015. https://doi.org/10.2779/975810

- European Red List of Marine Fishes. Nieto et al., 2015. https://doi.org/10.2779/082723

- European Red List of Grasshoppers, Crickets and Bush-Crickets. Hochkirch et al., 2016. https://doi.org/10.2779/60944

- European Red List of Lycopods and Ferns. García Criado et al., 2017. https://doi.org/10.2305/IUCN.CH.2017.ERL.1.en

- European Red List of Saproxylic Beetles. Cálix et al., 2018. Update to Nieto and Alexander, (2010). https://portals.iucn.org/library/node/47296

- A miniature world in decline: European Red List of Mosses, Liverworts and Hornworts. Hodgetts et al., 2019. https://doi.org/10.2305/IUCN.CH.2019.ERL.2.en

- European Red List of Trees. Rivers et al., 2019. https://doi.org/10.2305/IUCN.CH.2019.ERL.1.en

- European Red List of Terrestrial Molluscs: Snails, slugs, and semi-slugs. Neubert et al., 2019. Update to Cuttelod et al., 2011. https://portals.iucn.org/library/node/48439

- European Red List of selected endemic shrubs. Wilson et al., 2019. https://portals.iucn.org/library/node/48438 
The European Red List is a review of the status of European species according to IUCN regional Red Listing guidelines. It identifies those species that are threatened with extinction at the regional level - in order that appropriate conservation action can be taken to improve their status.

This publication summarises results for all Europe's native species of tree (454 species). Of these, 168 (42.3\%, mid-point value) of the species are threatened with extinction at the European level. This European Red List was compiled by IUCN and BGCI with support from the IUCN Species Survival Commission and other experts.

This report is a deliverable of a LIFE project co-funded by the European Commission (LIFE European Red Lists, LIFE14 PRE/BE/001), Establishing a European Red List of Bryophytes, Pteridophytes, Saproxylic Beetles, Terrestrial Molluscs and Vascular Plants

The report is available online at http://ec.europa.eu/environment/nature/conservation/species/redlist

and https://www.iucnredlist.org/regions/europe 